\title{
الالالي والتداولي في شعر مروان بن أبي حفصة
}

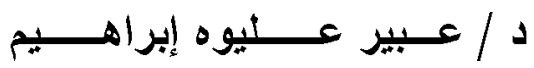

أستاذ مساعد قسم اللفة العربية

كليـــــة الآداب - جامعـــــــة الززقازيق

$$
\text { بسم الله الرحمن الزحيم }
$$

المقدمـــــة

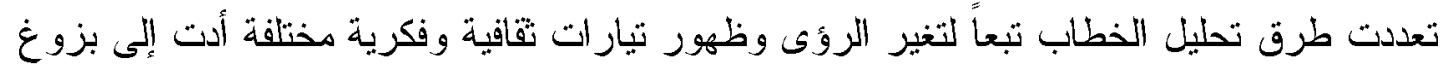

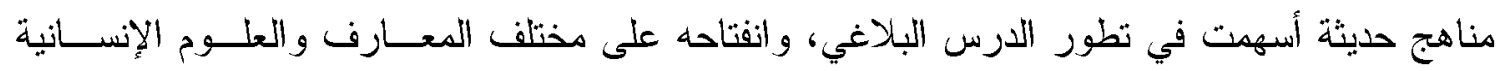
و الثقافية، وفي الوقت الذي اتجه فيه محللو الخطاب إلى تحليل الخطابات بالاقتصار على معناها اللغوي،

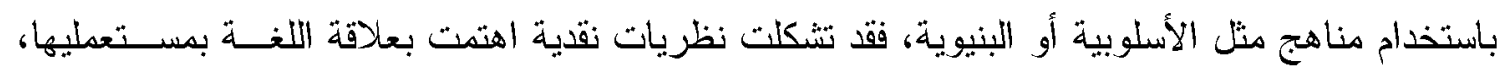
مثل: التداولية، وعلم النص، و البلاغة الجديدة/الحجاجية، واتجهت تلك النظريات نحو دراســة الخطــاب التهاب

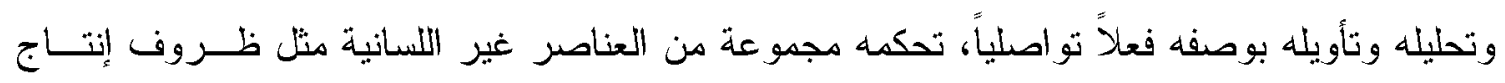
القول، ومقاصد المتكلم، وسياقات الاستعمال.

في ضوء ما سبق يسعى هذا البحث إلى تحليل النص الشعري من حيــث ارتبـــاط بنيتـهـه بالســياق

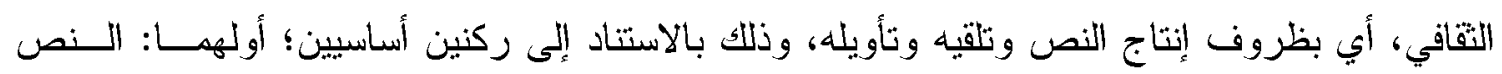

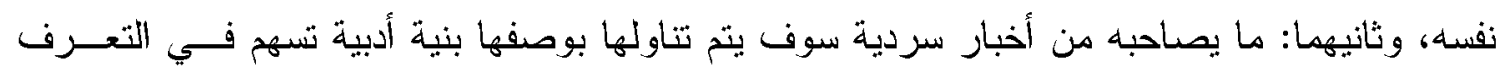

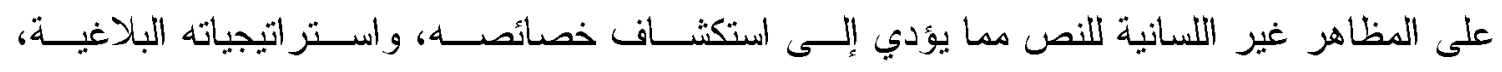

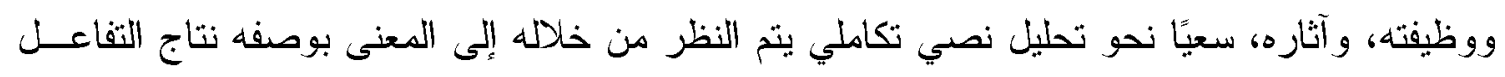

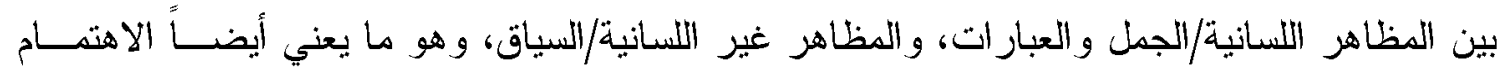

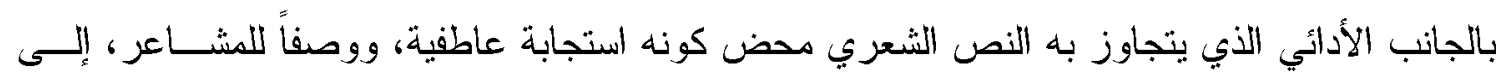

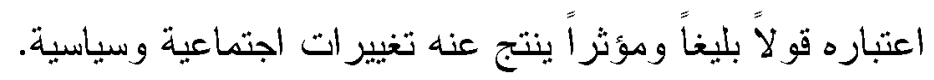

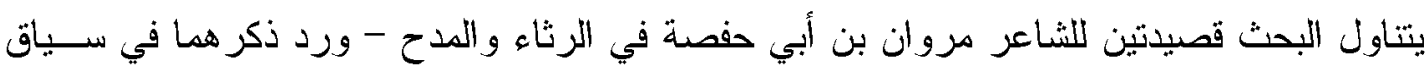

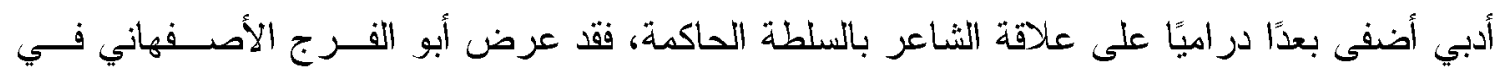

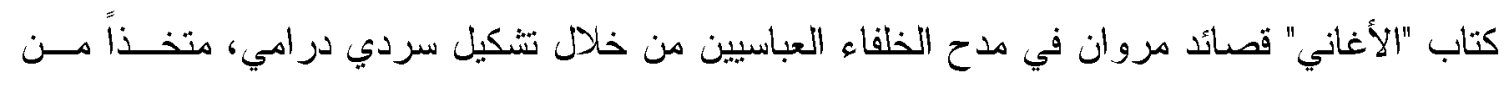

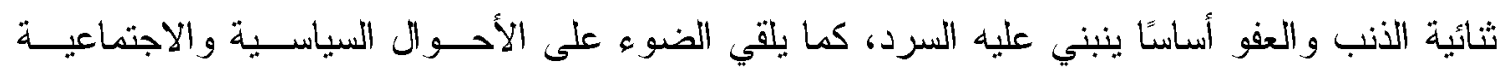

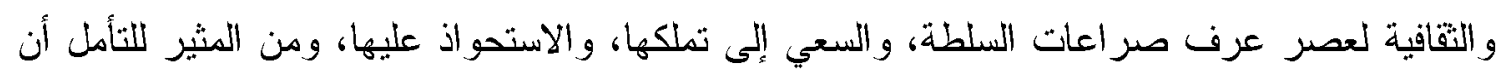

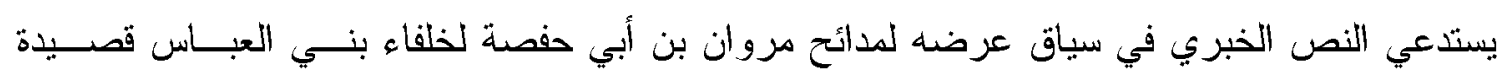

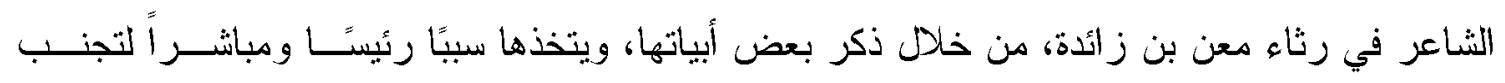

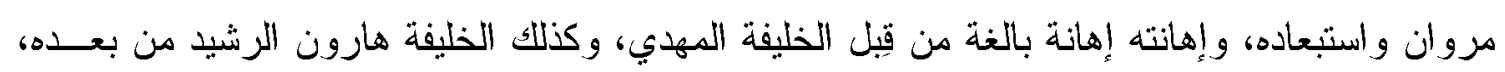


ثم تأتي قصائد المدح بعد ذلك لتجعل مروان بن أبي حفصة شاعر البلاط العباسي الذي نال من أيسـوال

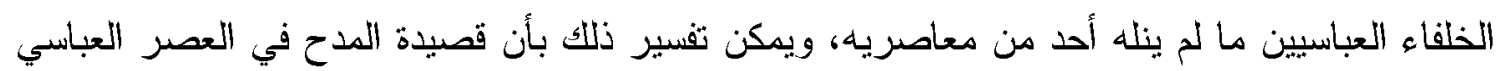

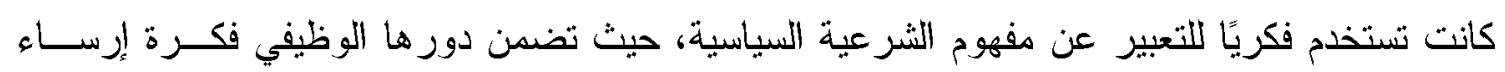

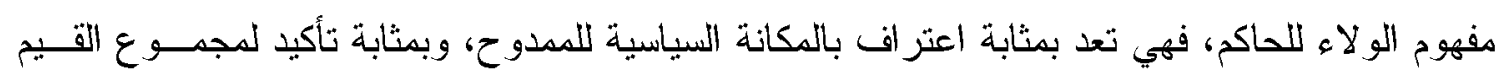
التي تعبر عنها، وذلك باعتمادها على الجوانب الجمالية والأدائية التي تمثل قيمتهابة الأدبية.

تثكل الأخبار السردية التي صاحبت قصائد الثعر اء سياقاً تقافياً أدبياً لتلك القصائد، وقد حفلت كتب لتبه

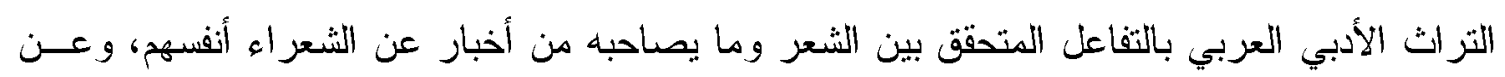

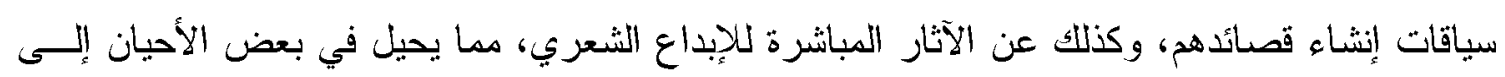

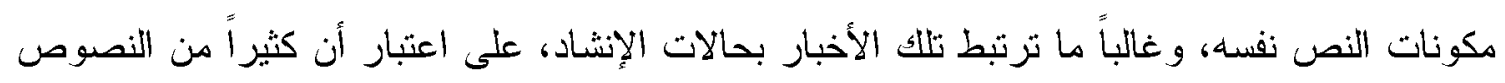

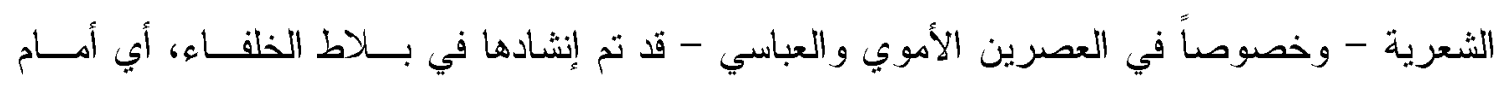

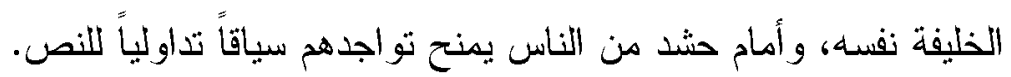

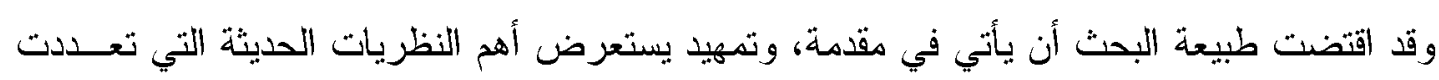

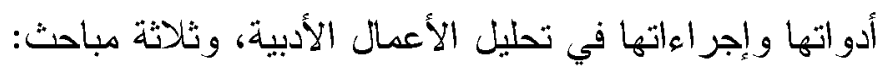
المبحث الأون: النص الثعري وسياقه النقافي. المبحث الثاني: بنية الفقد / قصيدة الرثاء.

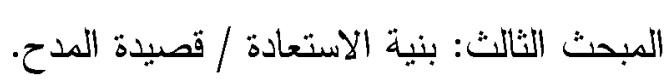
ثم خاتمة تعرض أهم النتائج التي سوف يتوصل إليها البحث.

\section{التمهيــــــــ}

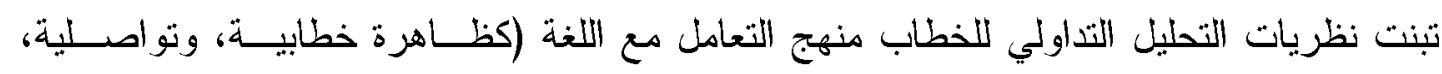

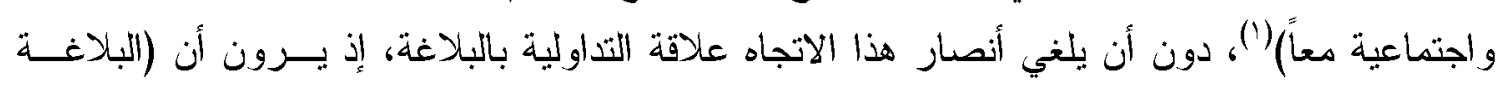

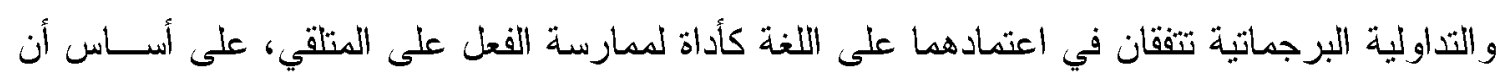

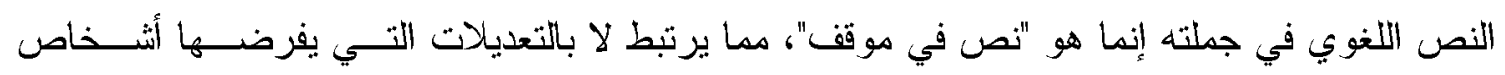

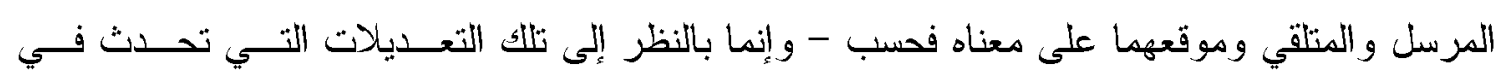
سلوكهما أيضاً) (r).

تأسيساً على ذلك ليست التداولية بديلاً عن البلاغة أو عن اللسانيات الثنكلية، فهي في نطاق اهتمامها

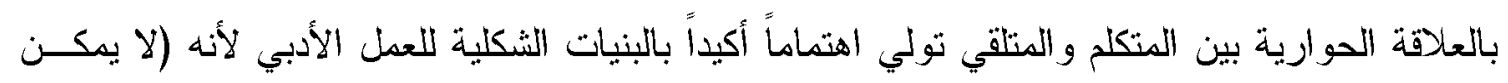

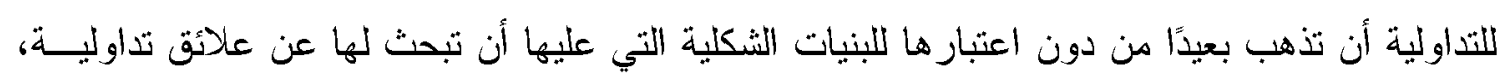

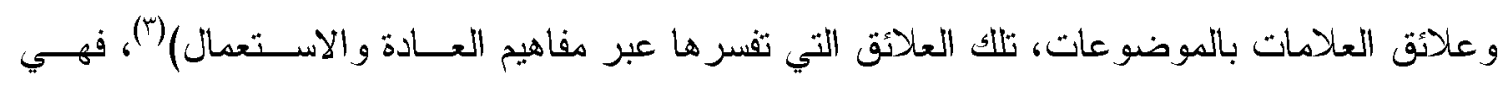


تعل على دراسة وتفسير البنيات الثكلية، مستعينة في ذلك بمعطيات تداولية، أي أنها نقرن بين القــول و الفعل، وبين المعنى و السياق.

مما تجدر الإثارة إليه أن (النظرية التداولية لها ثلاثة مفاهيم رئيسة: السياق، و القصد، والاســـلال.

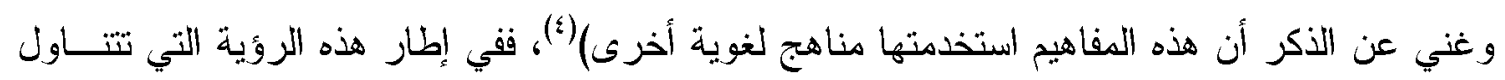

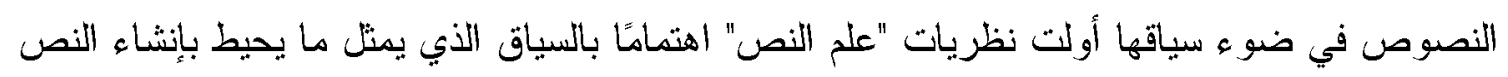

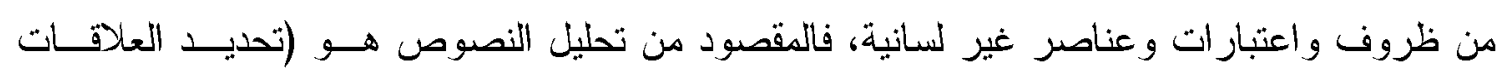

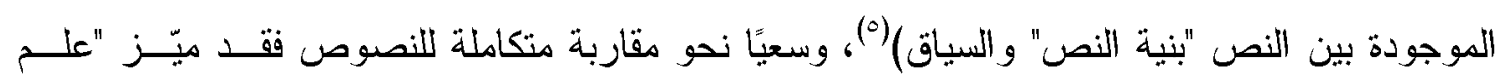

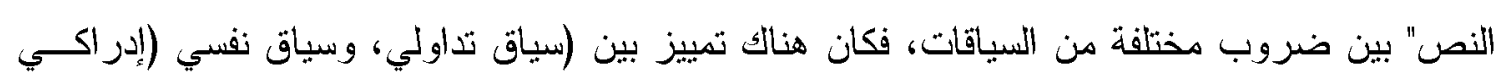

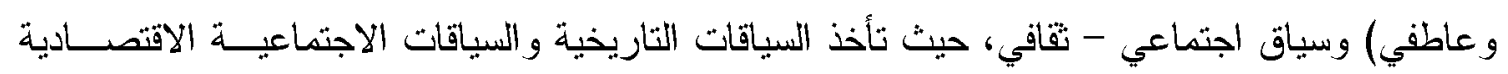
مكانها) (ج)

لقد كان اهتمام علم النص بالسياق إلى الحد الذي أدى إلى تتوع التحليل النصي بناء على التفرقة بين

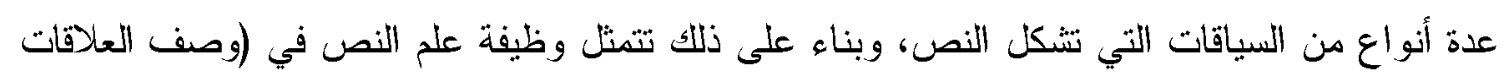

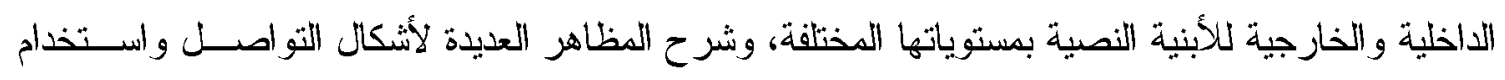

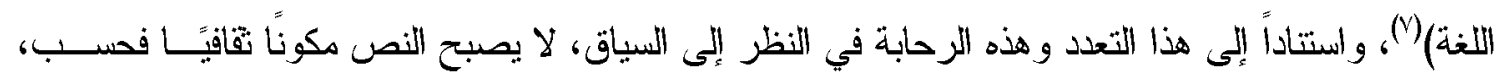

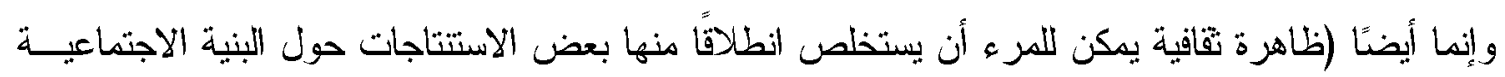

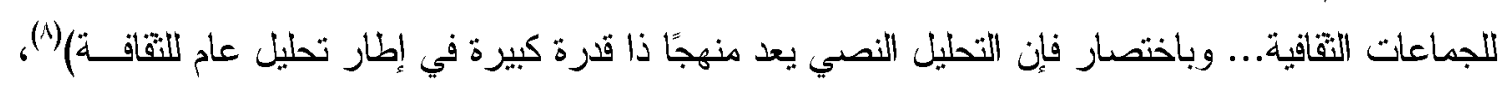

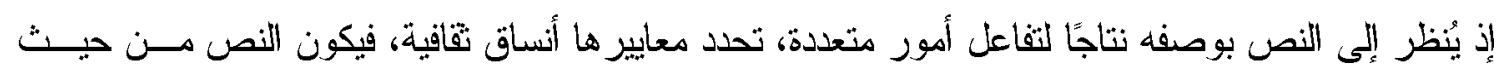

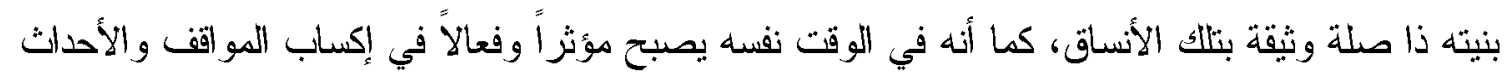
قيمتها التاريخية.

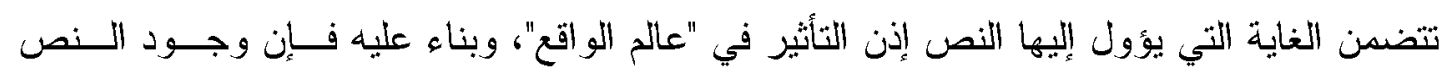

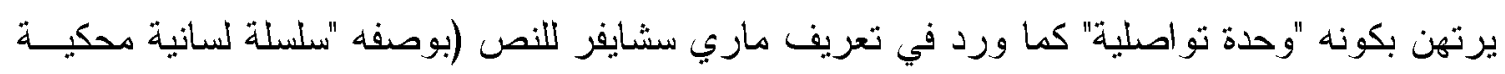

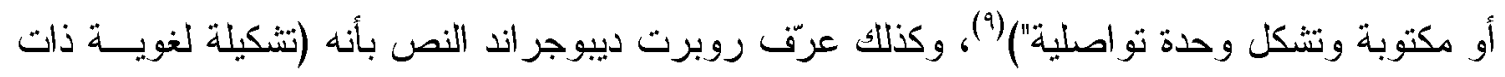

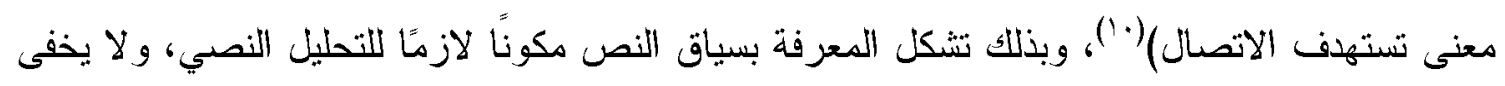

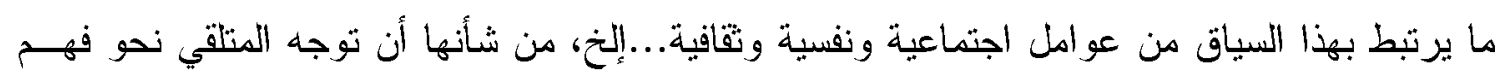

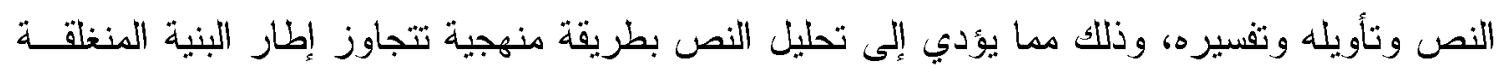

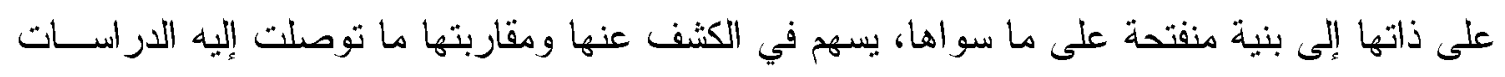
الإنسانية و العلوم المختلفة.

من بين الكفاهيم المحورية التي يوليها "علم النص" أهمية: "القصدية" و "القبول" إذ (يعد كل نص بنية

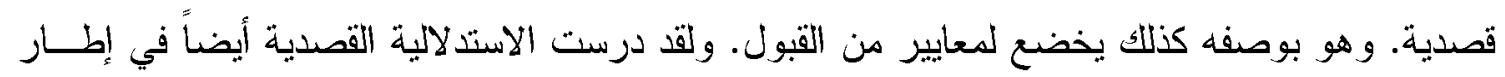

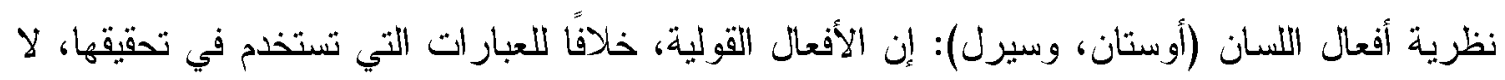

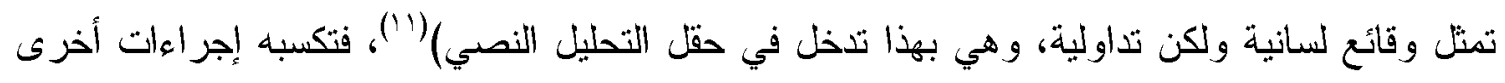


بانفتاحه على مناهج تتعمق في البعد التو اصلي للخطاب، و إذ تتمثل أفعال اللسان في تعبيــرات المــنكلم باستخدامه جملة أو أكثر يهدف من خلالها إلى تحقيق فعل ما في سياق محدد فإن فان ديك يرى أنه (بما

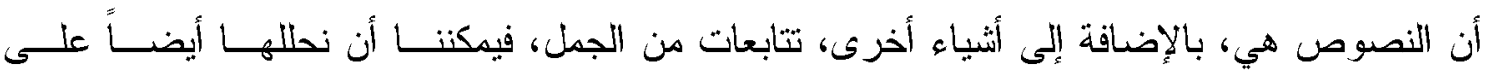

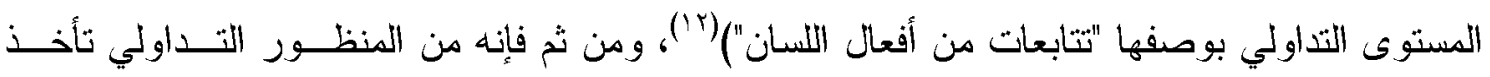
اعتبار ات إنشاء النص وظروف تلقيه أهمية في المناهج الحديثة. بناء على ذلك اهتمت الدراسات النقدية للقصائد العربية القديمة بظروف إنشاء القصائد، وبســاقات إلقائها وتداولها، وبالجانب الأدائي لموضو عاتها الكبرى كالمدح و الهجاء و الفخــر ، و أســهـت الأخبـار

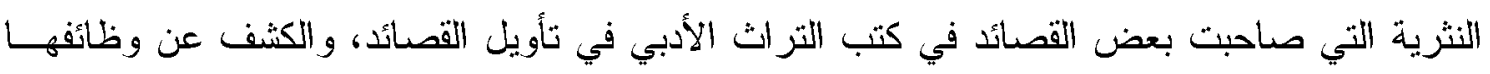

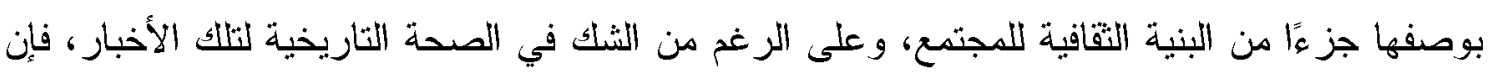

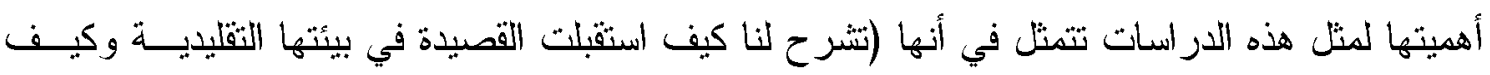
فسرت)("')، وذلك من خلا عرض الأحوال السياسية والاجتماعية وقت إنشاء النص، و عند تحليل تلاك

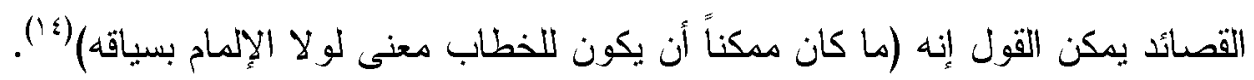

\section{المبحث الأول}

\section{النص الثعري وسياقه الثقافي}

يعد كتاب الأغاني لأبي الفرج الأصفهاني واحدًا من الكتب التي اشتملت على العديد من المقطوعات

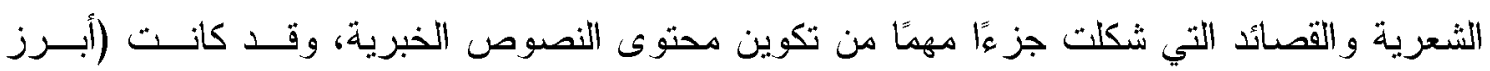

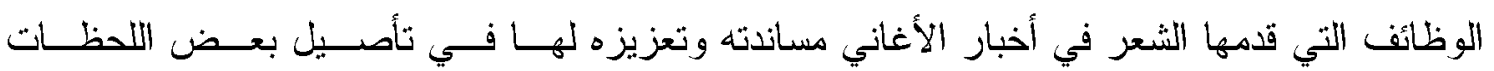

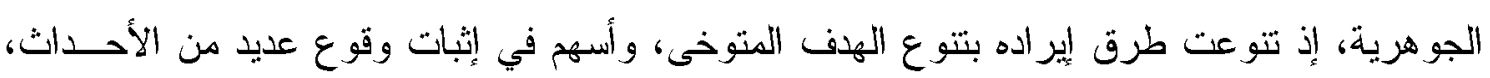

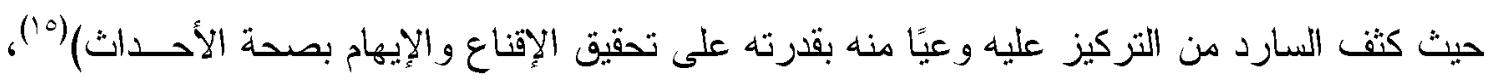

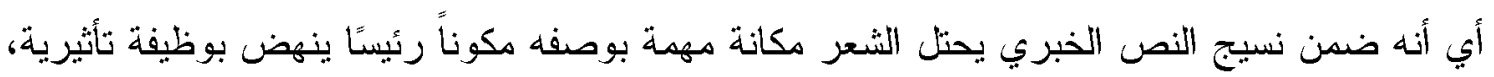

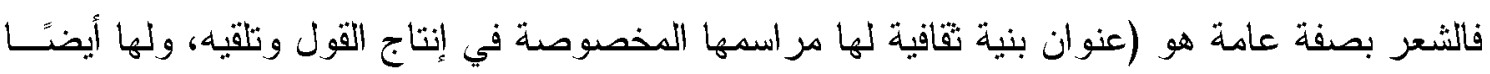

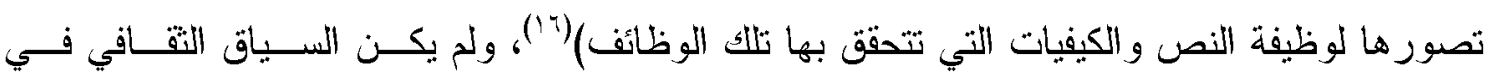

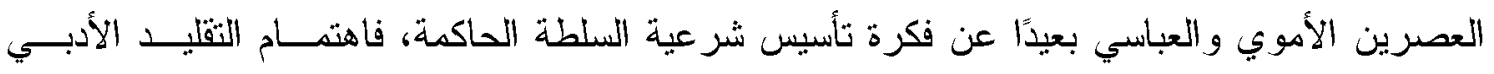
العزبي بقصائد مدح الخلفاء والو لاة بعد أحد تجليات هذه البنية التقافية. إن الأخبار التي صاحبت شعر مروان بن أبي حفصة في الرثاء وما تلاه من قصائد مــدح تكتسـبـ

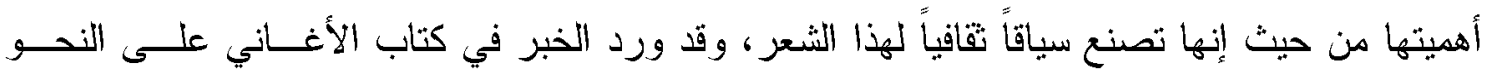
التالي: (أخبرني حبيب بن نصر قال حدثا عبد الله بن أبي سعد قال حدثي عبد الله بن محمد بن موسى

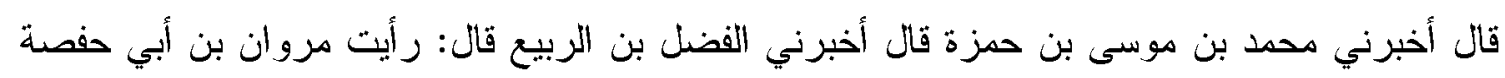

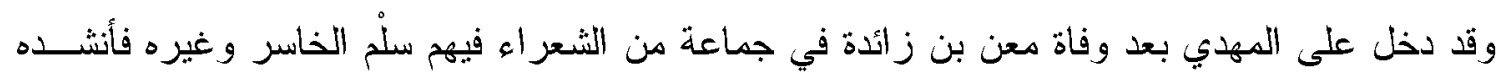


مديحًا فيه، فقال له: ومن أنت؟ قال: شاعرك يا أمير المؤمنين و عبدك مروان بن أبي حفصة. فقال لــه المهدي: ألست القائل:

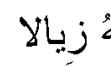
لانريب

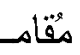

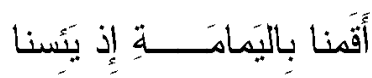

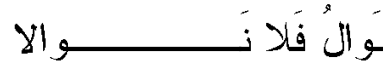
وَقَد ذَهَبَ النَ

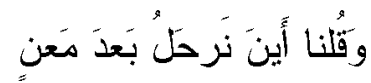

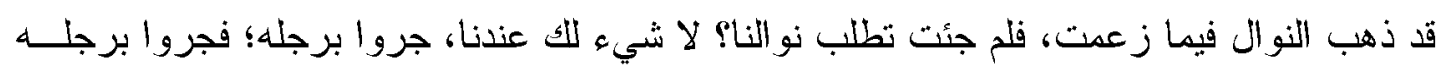

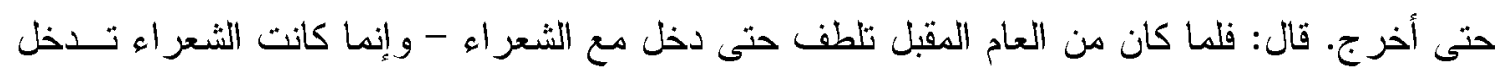

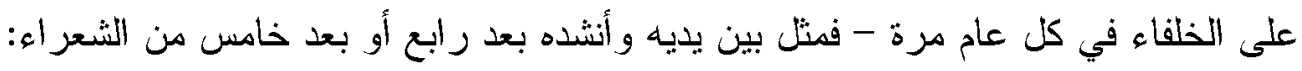

باءُ نَخَلِطُ بِالحَيَاءِ دَلاَلَها قادَ القُلوبَ إلىى الصِيا فَأَماكَ

$$
\text { قال : فأنصت الناس لها حتى بلخ إلى قوله: }
$$

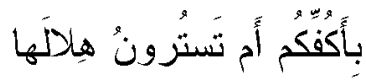

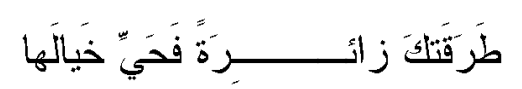

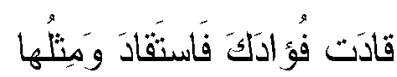

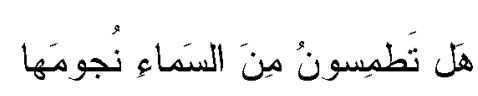

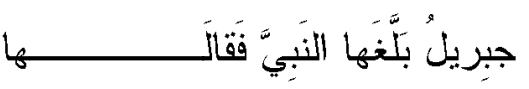

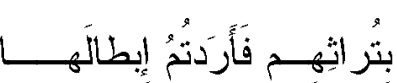

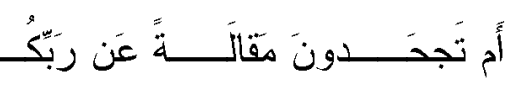

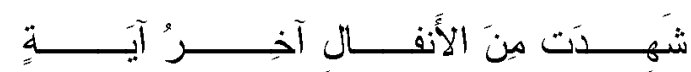

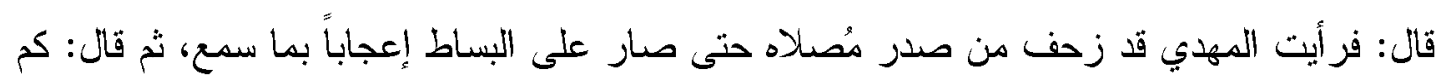

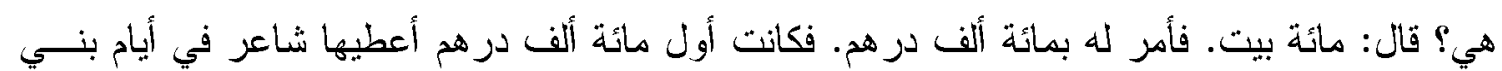

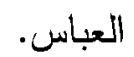

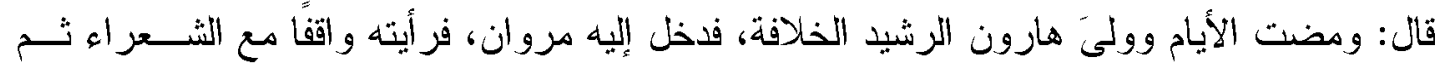

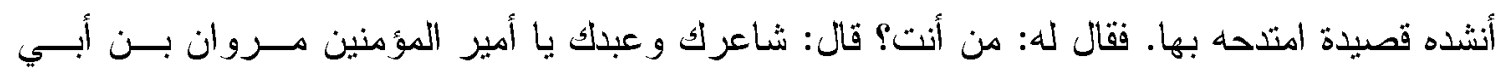
حفصة. قال له: ألست القائل في معن بن زائدة و أنثده البيتين اللذين أنشده إياهما المهدي، ثم قال: خذوا بيده

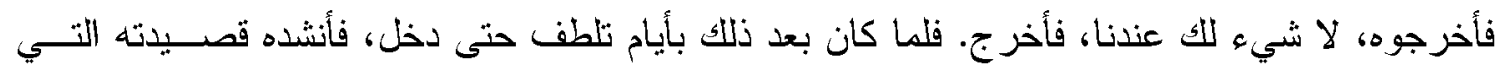

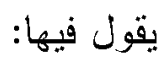

بـ بالبَنان المُخَضَّبَ

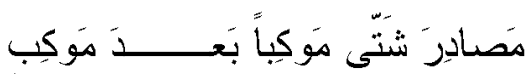

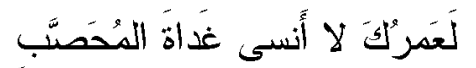

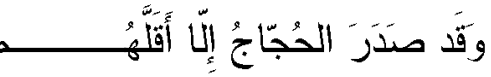

قال: فأعجبته، فقال: كم قصيدتك من بيت؟ فقال: ستون أو سبعون. فأمر له بعدد أبياتها ألو فا. فكان

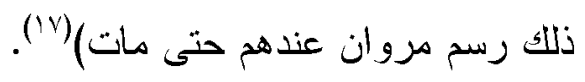


عرض الخبر قسوة تعامل خلفاء بني العباس مع مروان بن أبي حفصة عند بداية وفوده علـى كـلـ

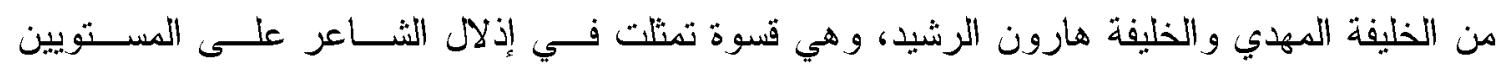

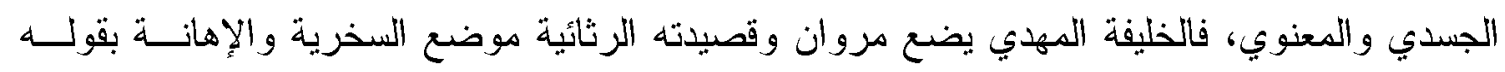

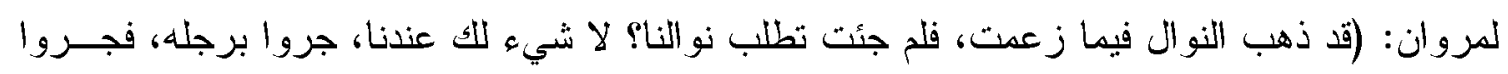
برجله حتى أخرج)، وكذلك فعل الخليفة هارون الرشبد عندما قال لمروان: (ألست القائل في معن بـن فئن

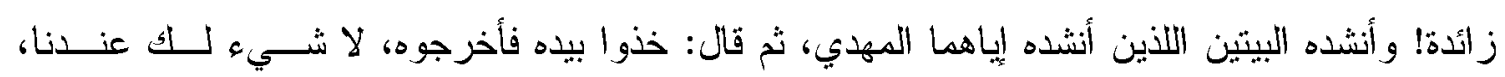
فأخرج)، هذا التكرار للحدث ذاته وأن أسه في استبعاد الصحة التاريخية للأحداث فإنه في الوقت نفسها

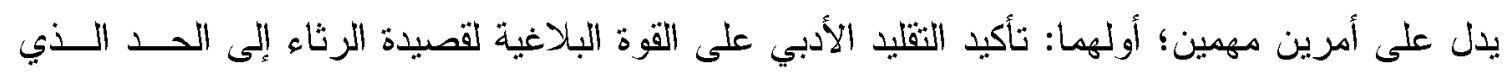

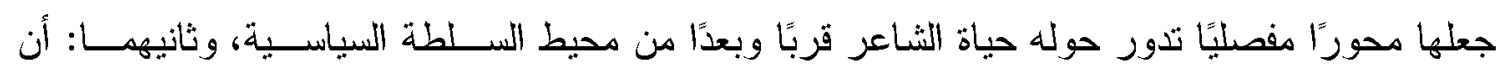
خطابات المدح التي أنشدها مروان بن أبي حفصة فيما بعد قد تم إنتاجها من أجل حل مشكلة العلاقة بين

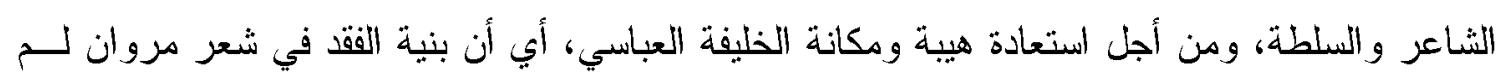

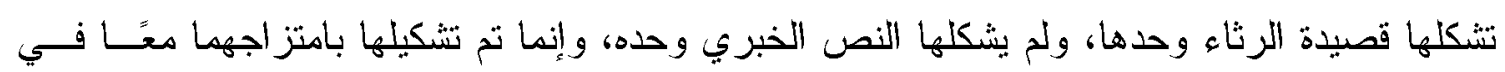
إطار سياق ثقافي يسعى إلى تأسيس شرعية السلطة الحاكمة.

لكنه مما يستدعي الاهتمام أن سياق تلقي القصيدة يثير التساؤلات حول مقصدها البلاغــي، فعنــدما

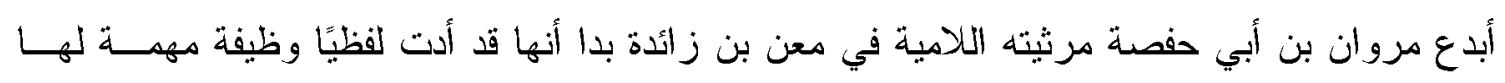

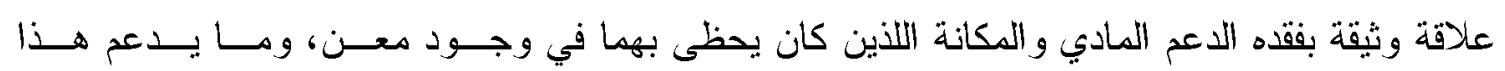

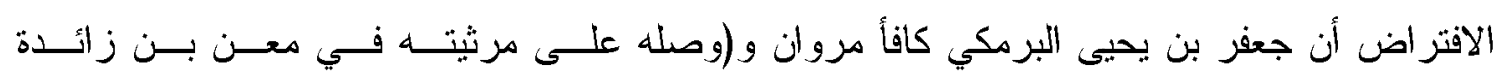
الثيباني)(")، أي أنه على حين أجاب جعفر بن يحيى البرمكي على التساؤل البلاغي الوارد على لسان

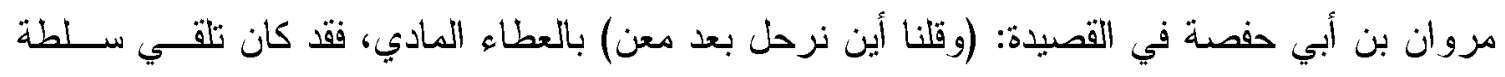

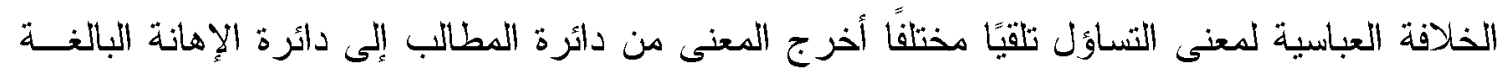

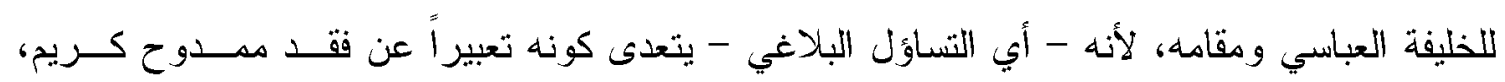
و المطالبة بعطاء بماثل عطاءه، إلى كونه وقاحة لفظية تحمل إنكارًا ضمنيًا لكرم الخليفة العباسي. إن تباين ردود الأفعال تجاه قصيدة الرثاء يستدعي الأخذ في الاعتبار أن تحليل النصوص الثــعرية

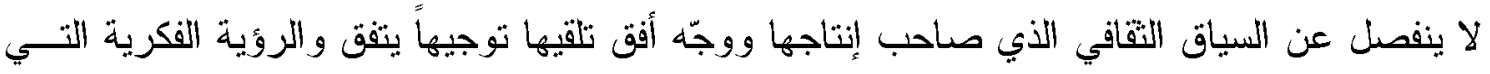
تحدد الاستجابات نحو العمل الأدبي، وما تتناوله دراسة باربرا بايسكر عن ارتباط النص ودلالاته بمقام

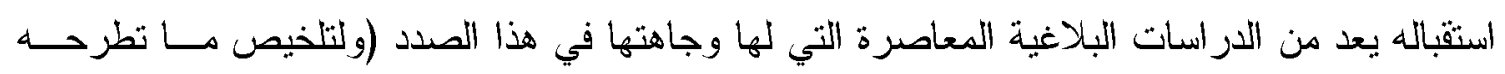

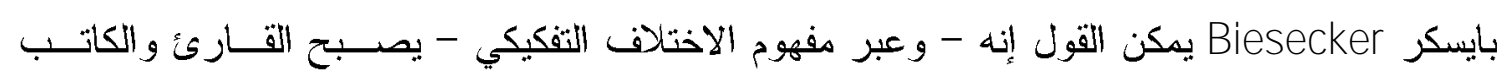
كلاهما منتجًا لمعنى الخطاب، فالمعنى هنا ليس واحدًا، و إنما يختلف من شخص إلى آخر، ومن ســياق

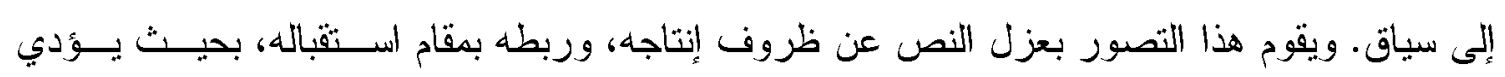

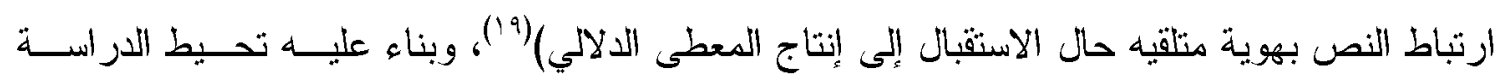

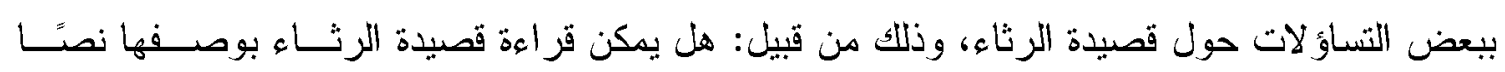


جماليًا ذا فعالية أدائية؟ كيف تتجلى الاستر اتيجية الإقناعية التي اعتمدها الثاعر في تشكيل بنية قصيدته؟ ما هي الصلة الرابطة بين محتوى الرسالة المتضدنة في القصيدة/ سياقها الثعري، والأثر الذي أسهمت في إيجاده/ سياقها الاجتماعي و السياسي؟

تفترض الار اسة أن مروان بن أبي حفصة لم يقصد بإبداعه قصيدته الرثائية أن بعبر عن مشــاعره

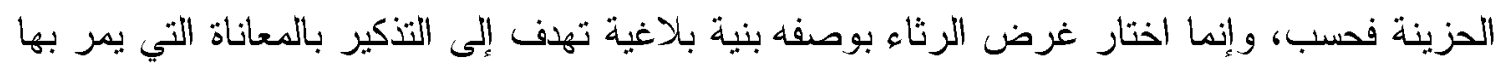

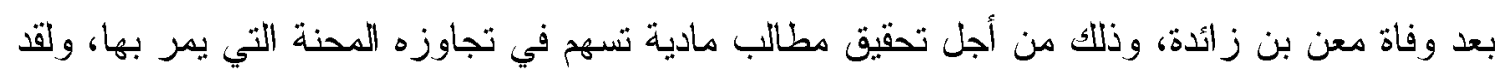
كان غرض الإقناع بصدق العاطفة من أهم المقاصد التي توسل مروان لبلو غها بوسائل لغوية وبلاغيــة

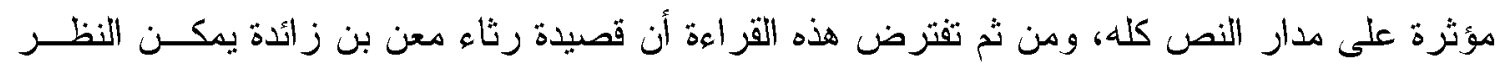

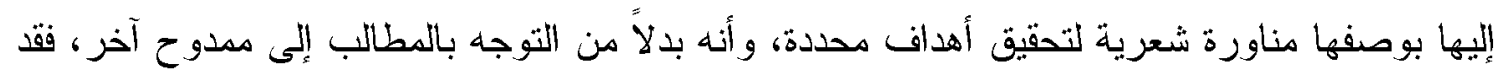

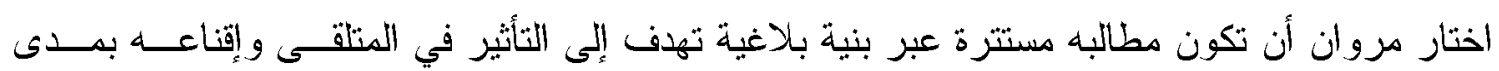

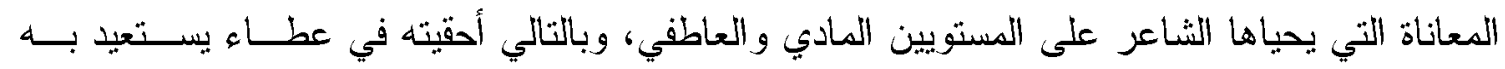
مكانته المجتمعية، ومما يعزز الافتراض السابق هو ما تبع عطاء جعفر بن يحيى البرمكي لمروان بــن

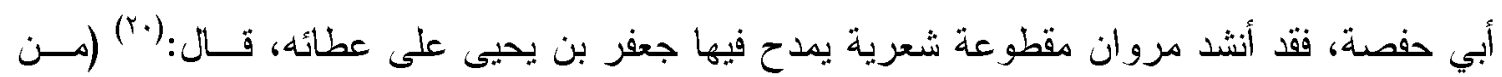
الو افر)

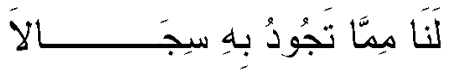

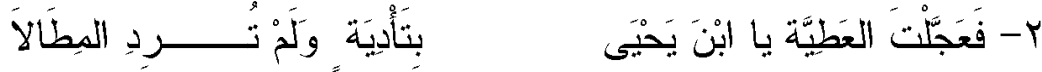

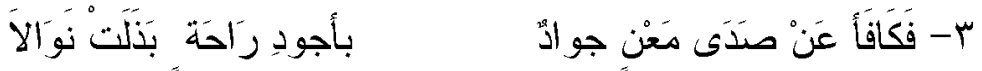

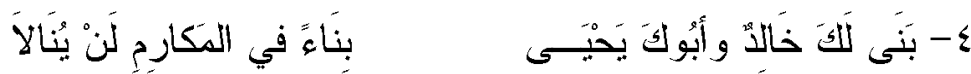

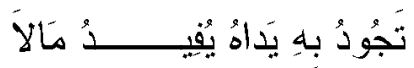

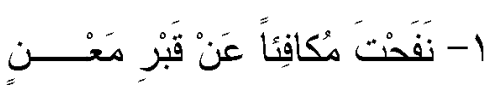

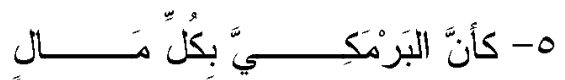

إن عبار ات مثل: "نفحت مكافيًا" البيت ا، (فعجلت العطية)، (لم ترد المطالا) البيــثـ ب، "فكافــأ...

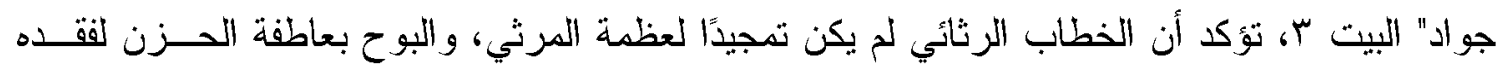

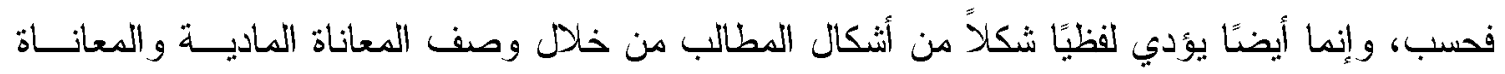

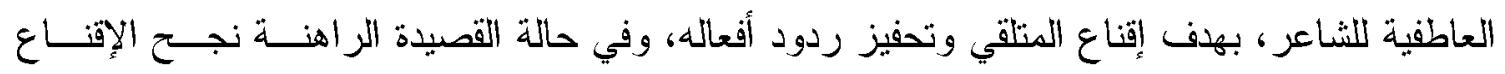
بصدق المشاعر في تحقيق استجابة فعلية/مادية من قبل جعفر بن يحي البرمكي. ليس من المستغرب إذن أن تشتابه القصيدة الرثائية والمقطوعة الشعرية في الوزن الشعري/ بحسر

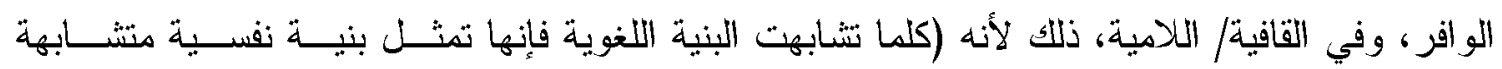

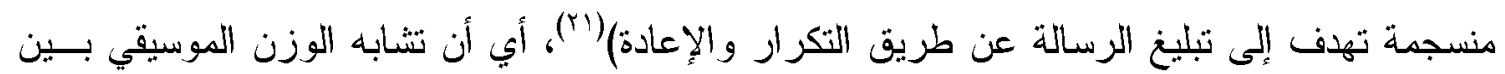


القصيدة والمقطوعة مما يفضي إلى استشعار وجود وحدة ما بينهما على الرغم من اختلاف الغـرض/ الزمال

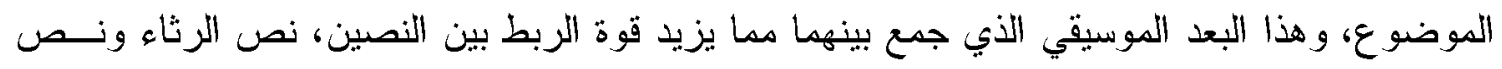

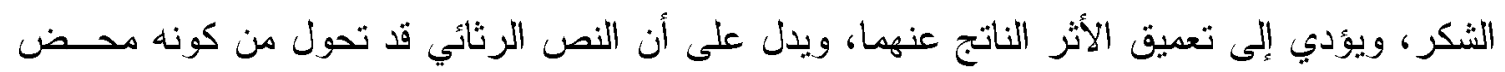

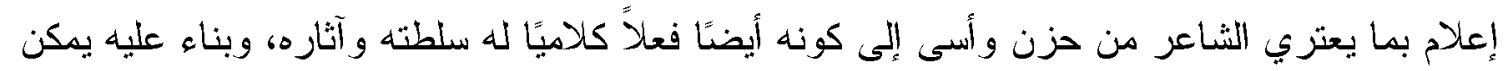
الآن تناول النص الشعري نفسه.

\section{المبحث الثاني}

\section{بنية الفقد / قصيدة الرثاء - مئ}

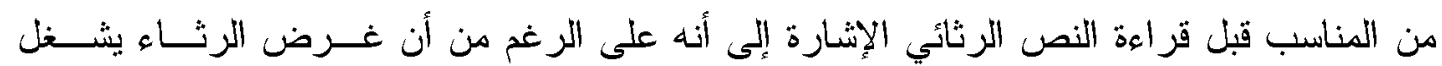

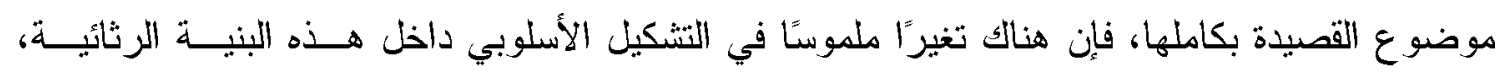

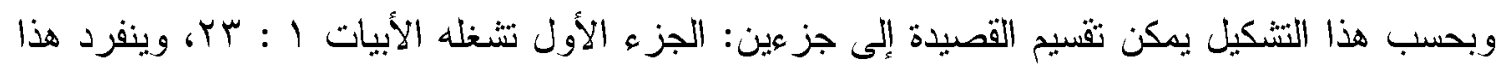

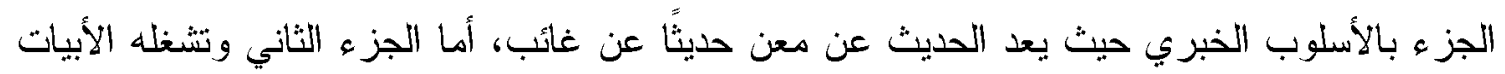

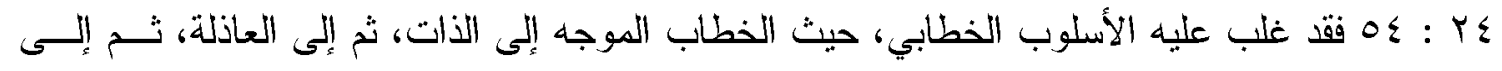

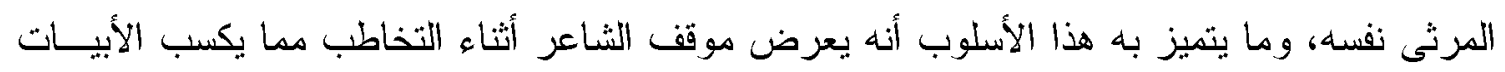

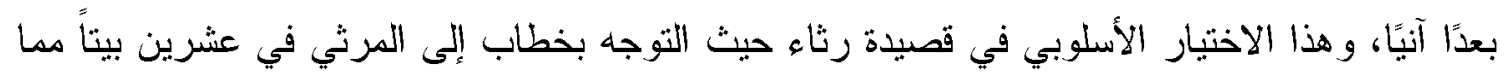

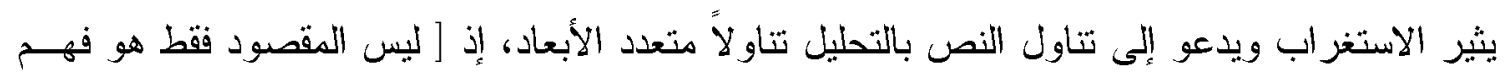

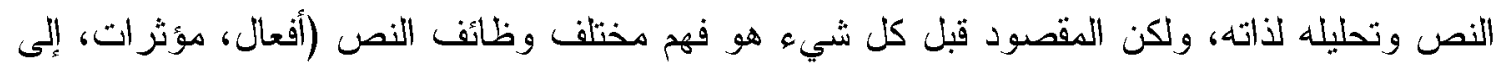

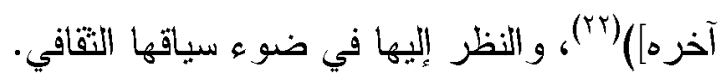

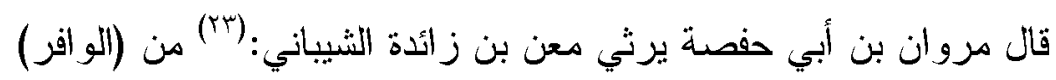

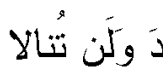

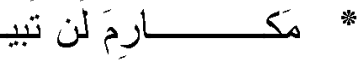

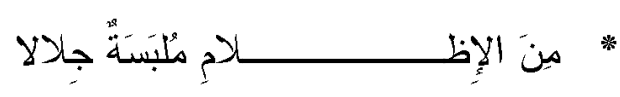

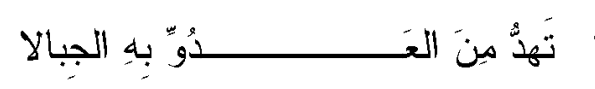

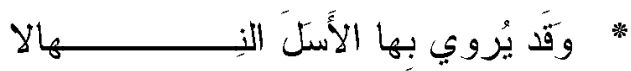
$\checkmark x$

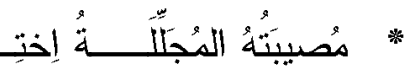

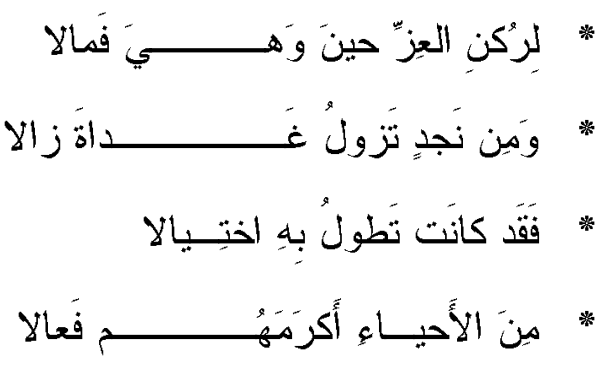

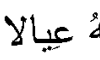

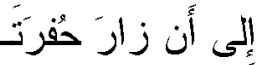

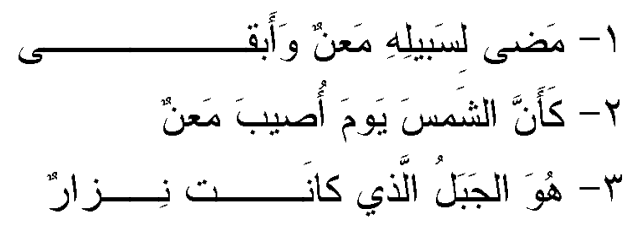

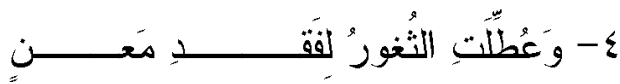

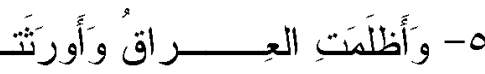

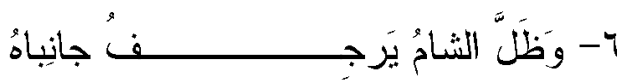

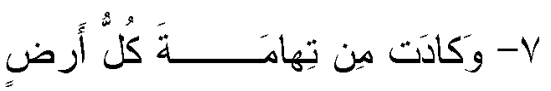
$\varepsilon$

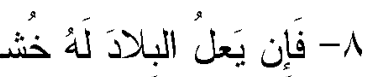

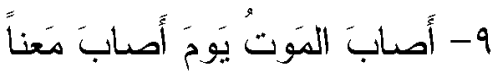

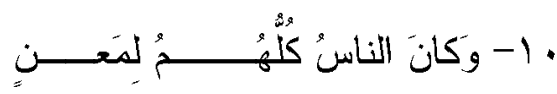


إلِى غَير اِبنِ زائَدَة ارِتِحالا

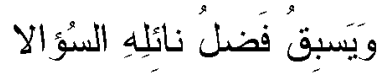

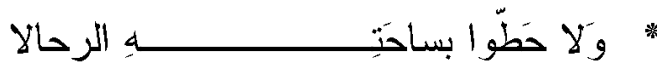

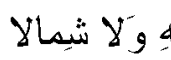

يَمَيناً مِن يَديب

مِنَ المَعروف مُترَعَةٌُ سِجالا

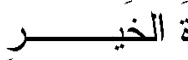

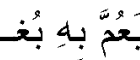

* مالا

لَرَ مَدَّ لَهُ فَطالا

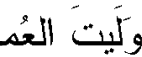

* سُيوفَ الهندِ وَالحَّقَ المُذالا

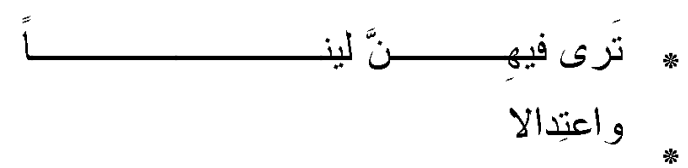

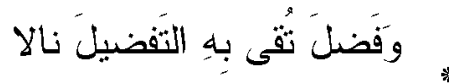

لمَهُ أَنْ تُذالا

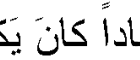

إنسالا بها عقباً ويَرْرِ

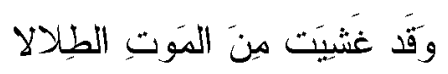

كـوكَ أَن تُقالا

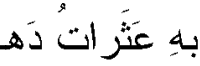

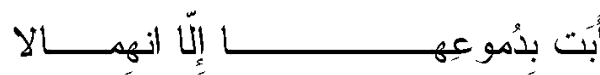

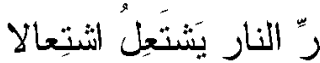

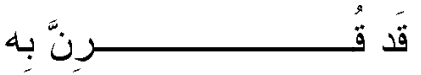
ليالـ

فَطالا

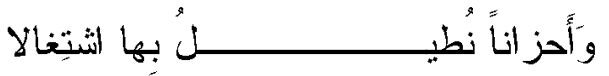

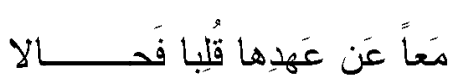

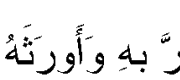
Vا

مين الهنديِّ قَد فَقَدَ الصِقِالا وُعالا " لفَجَع مُصينَةٍ أَنَك
11

با - مَضى من كانَ يَحمِلُ كُلَّ تِقل

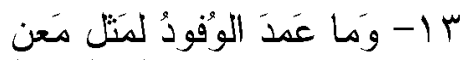
ـا- وَلا بَلَغَتَ أَكُفْ ذَوبي العَطايا

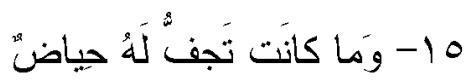

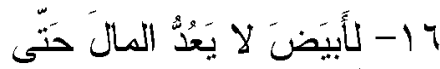

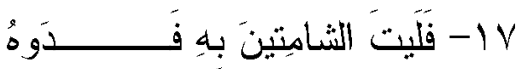

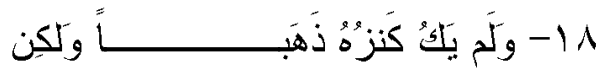

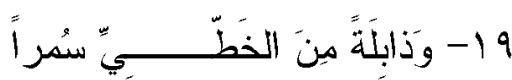
• r- وَذُخرَاً مِن مَحامِدَ بَاقِيـاتِ

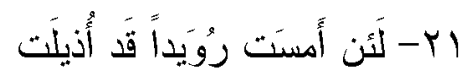
ب ب- لَقَد كانَت تُصـابُ بهِ وَيَسمو

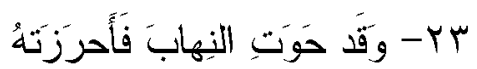

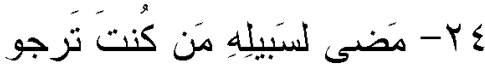

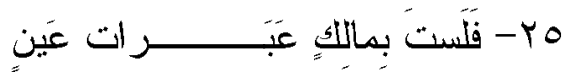

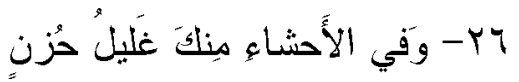

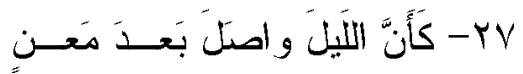

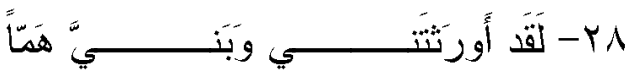

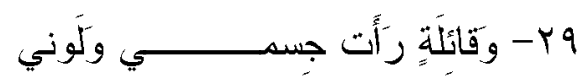

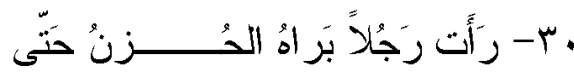
اسب- أَرى مَروانَ عادَ كَني نُحول

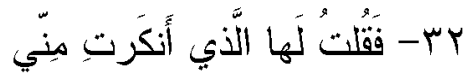

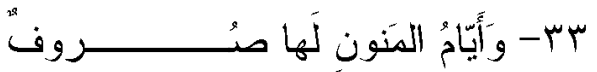

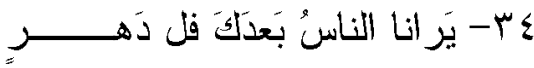
هب- فَحنَ كَأَسهُْ لَمَ يُيق ريشاً 
$y$

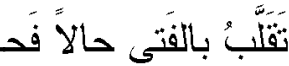

إلّا اغتيالا أبي لجُو دِن

* لَها رَيَبُ الزَمَان وَلا نصالا

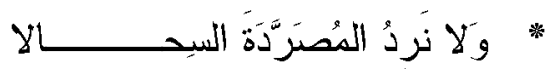

* جُعِلنَ مُنى كَ انِبَ وَاعتِلالا تِقالا

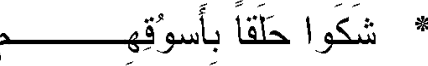

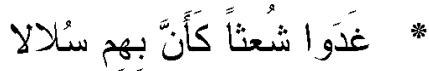

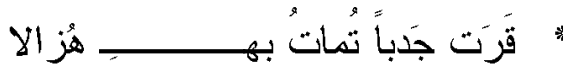

* لَها تُلقى حَو المِلُها الستِّالا

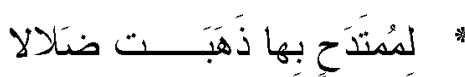

* يَّولُ لَهُ النَجِيُّ أَلا إِحتِالا

تجُ لَهُهُ زيالا * مُقامًا لا نُريـ

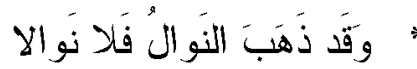

عَو ابسَ قَد كَفَتَ بها رعالا

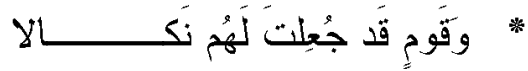
بال

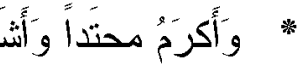
إذِا هُوَ بَالأمورِ بَلا الرجمِالا

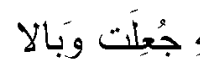
" على أُعدائُ

(النز

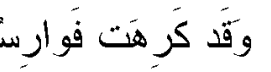
هَعَ المِدَح اللَّواتي كانَ قَالا يُطيلُ بو اسبطِ الرَحل اعتقالا

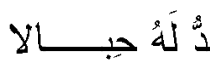
يَمَيناً لا يَتِ
بس- وقَد كُّا بحَوضِكِكَ ذاكَ نَروي

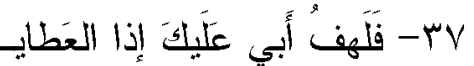

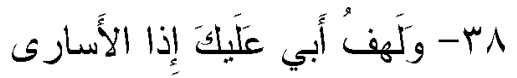

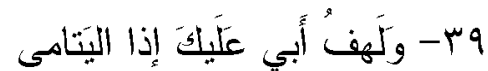

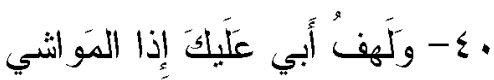

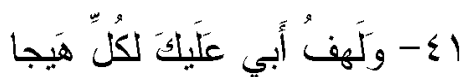

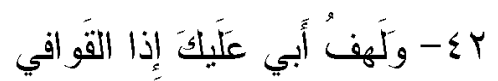

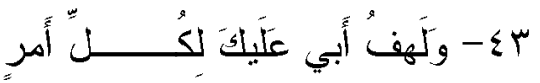
گ

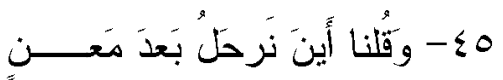

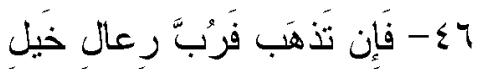

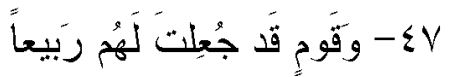

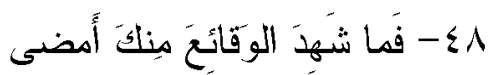
؟ - سَيَكُرُكَ الخَلَفِةُ غَيرَ قَال • - - وَلا يَنسى وقَائعِكَ اللَو اتي

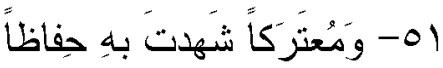
به- حَباكَ أَخو أُمَيَّةَ بِالمَرَ اتَي به- أَقامَ وكَانَ نَحَكَكَ كُلَّ عامِ

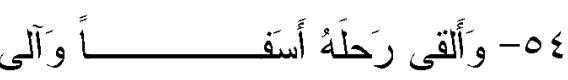
الجزء الأول: الأبيات 1 - بr 


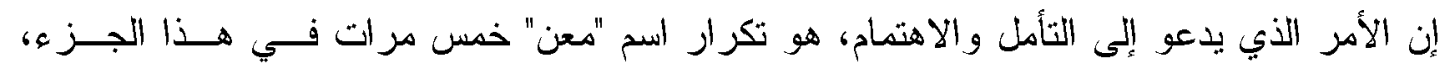

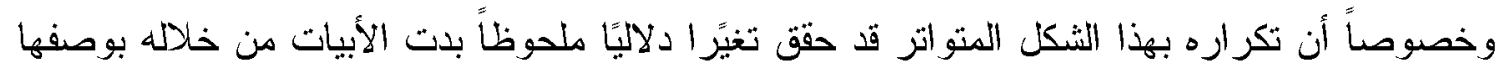
مجموعة من المشاهد المتتالية التي ما إن ينتهي أحدها حتى يبدأ آخر، ويدرك المتلقي عندما يذكر اســ

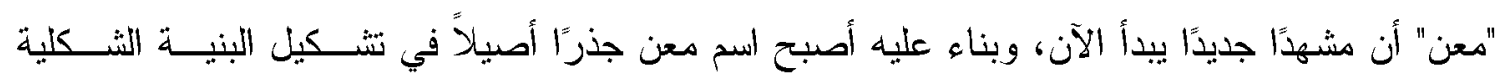

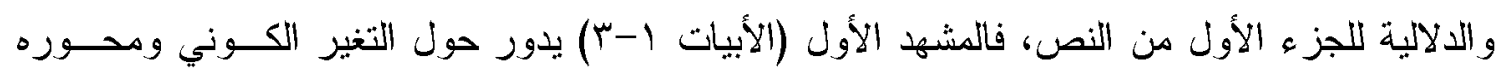

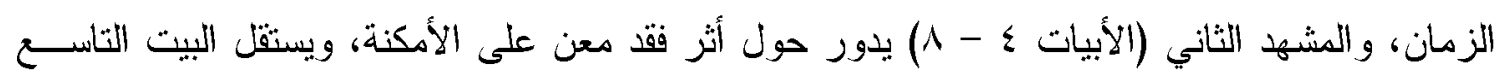

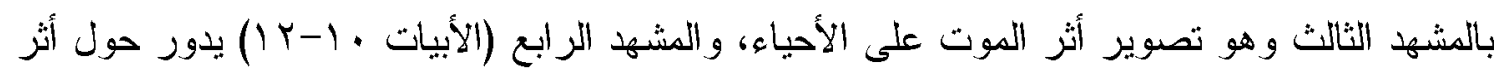

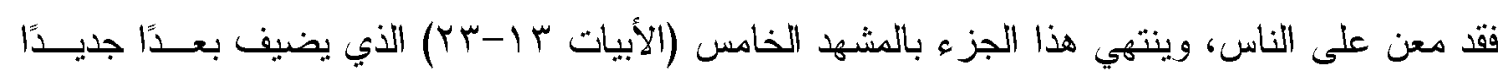
يختص بفضائل معن حيث كرمه اللامحدود، وقوته العسكرية التي لا تضاهى، وهذه المشاهد كلها تبــــأ

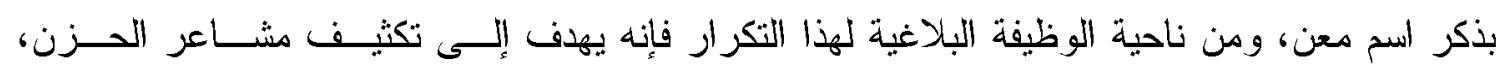
والاخول بالمتلقي إلى عالم الثاعر النفسي.

المثهر الأول: (الأبيات ا-ب). يفتتح مروان هذا المشهد الذي يمثل بداية القصيدة بالفعل "مضــى"،

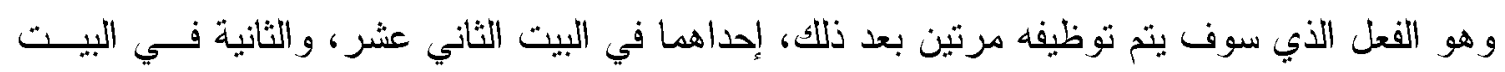
الر ابع و العشرين الأبي يؤذن ببداية الجزء الثاني من القصيدة، أما التأثير البلاغي لهذا الاستخدام المتكرر

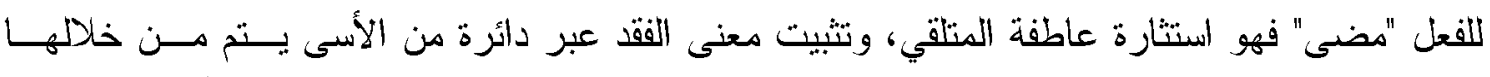
تكر ار اللفظ ليشكل الأساس الدلالي لهذه البنية، كذلك يعرض الثاعر في البيت نفسه تقابلاً بين الفعلـين

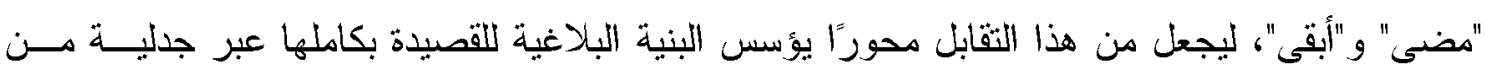
التفاعل بين الأفعال الدالة على الققد، والأفعال الدالة على استمرارية الحياة. هذه المر اوحة بين النقيضين تجسدها في البيت r صورة شعرية لا تخلو من بعد نفسي عميق: "كأنَّ

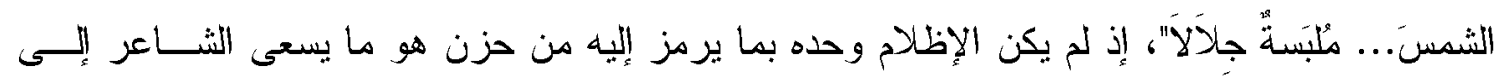

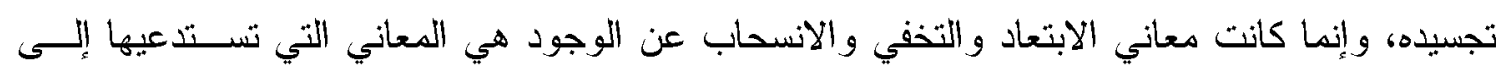
الذهن صورة الغطاء الذي تلبسه الذابة من أجل أن تصان به، ولا تخله هذه الصدورة أيضًا من معساني

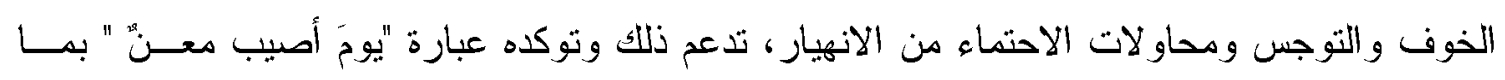
تحمله من دلالة الفجيعة المفاجئة و عدم القدرة على تحملها، وبذلك جمعت هذه الصورة برهافة هافة بلاغبـة

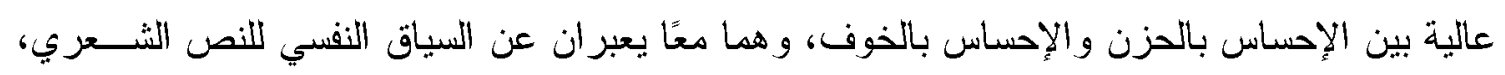
حيث الأسى الذي يصحبه الخوف وعدم وضوح الرؤية، إنه الموقف النفسي الأبي يعترب الناعر لفقدانه من كان له في الحياة دعم وسند، ولذا يختتم مروان هذا المشهد بصورة شعرية ذات بعد ثقافي تجسد قوة

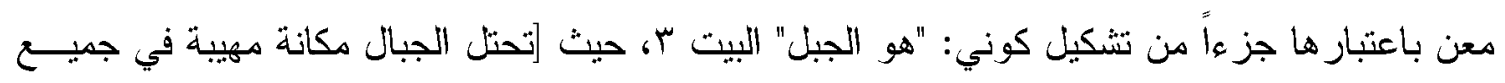

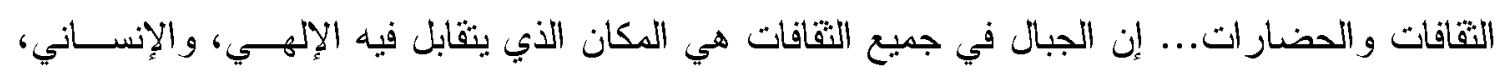

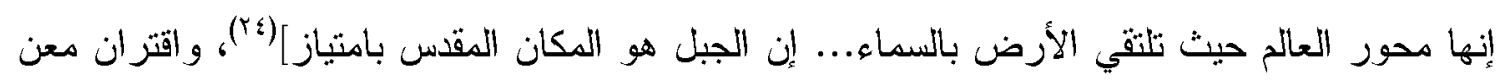
بالجبل يضفي عليه تلك المهابة، ويجعل منه مركزًا لقوة الأرض، وسندًا ودعماً للناس جميعًا. 


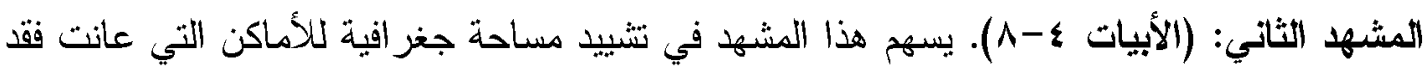

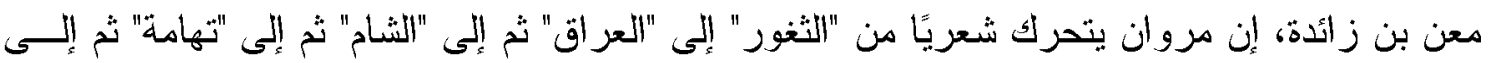
"ند" مثتصيًا حالات التغير الذي أصاب البلاد كما لو كان يرسم أنثر الغياب من خلال علامات الإقِقـار

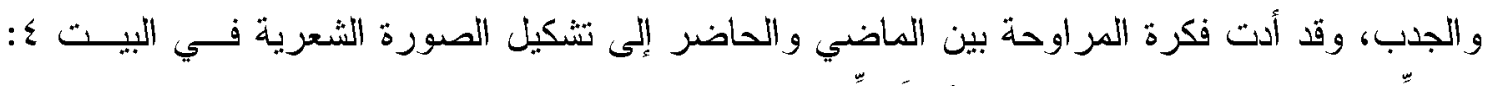

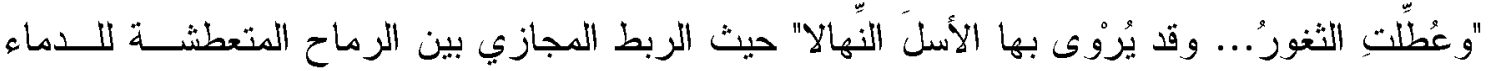

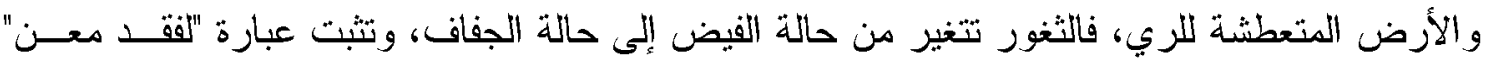

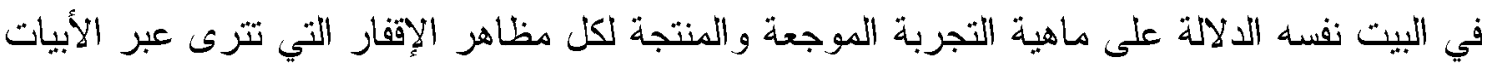

مها يثير الانتباه في الأبيات التالية ه - 1 هو ما تتطوي عليه مظاهر الإققار من بعد نفسـي، هــا

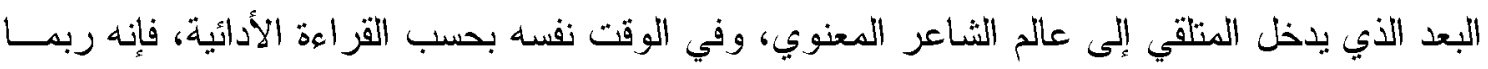

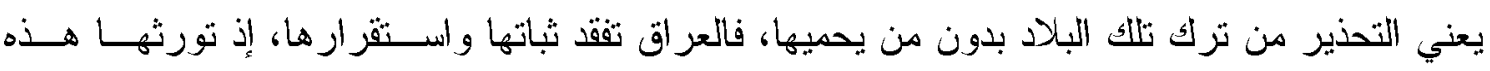

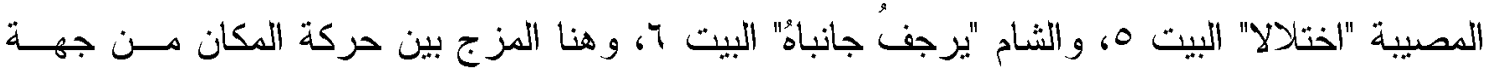

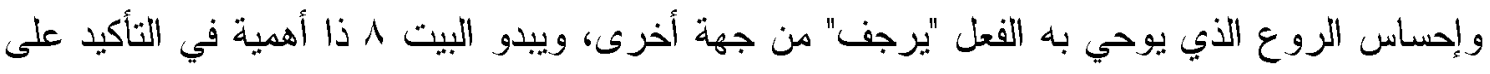

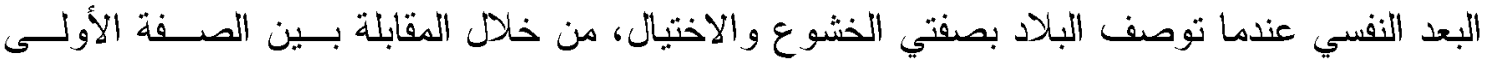

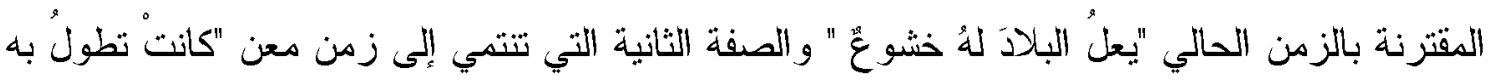

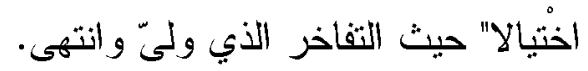

المشهد الثأث: (البيث 9). بناء على أن جميع المشاهد تبدأ بذكر اسم معن، فإنه لا يمكن تجاهل أن

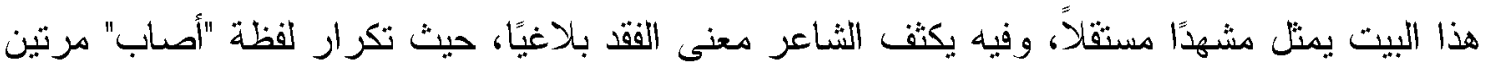

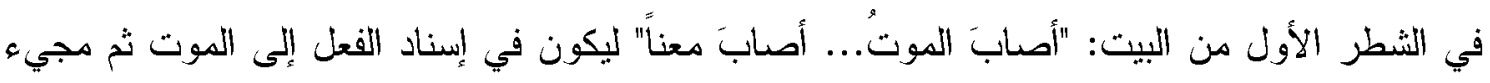

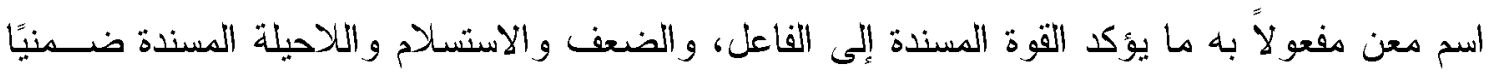

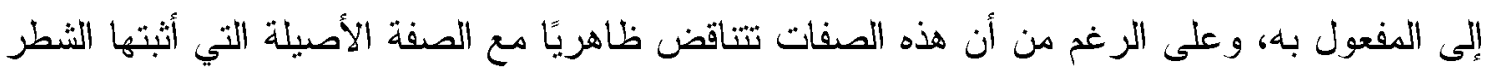

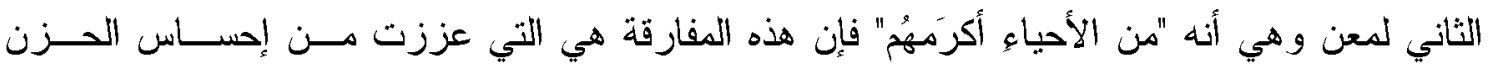

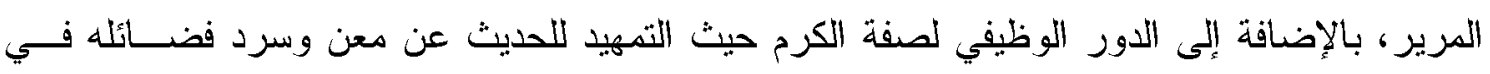

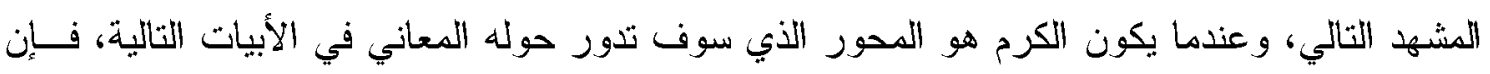

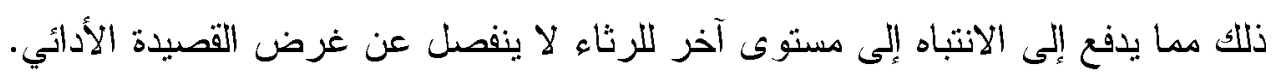

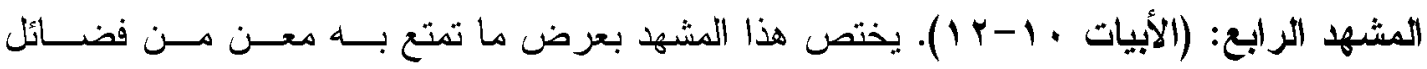

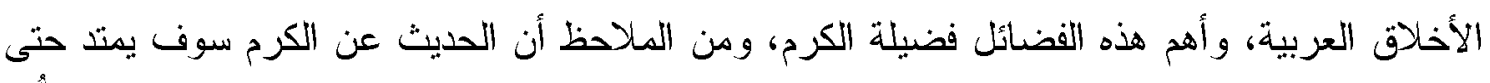

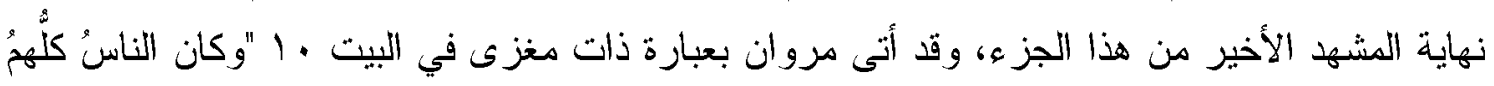

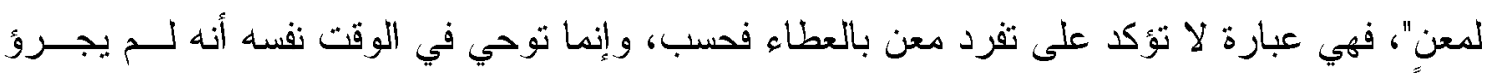

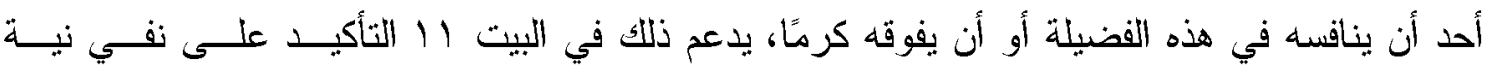




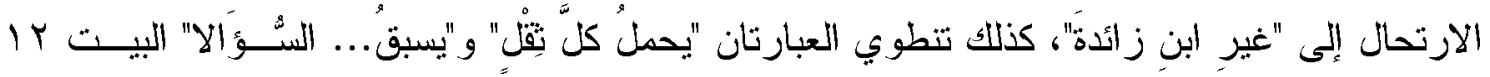
على معنى النبل و المبادرة إلى تحمل الأعباء.

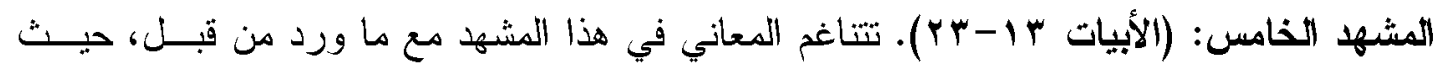

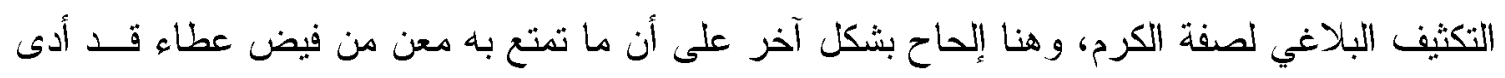

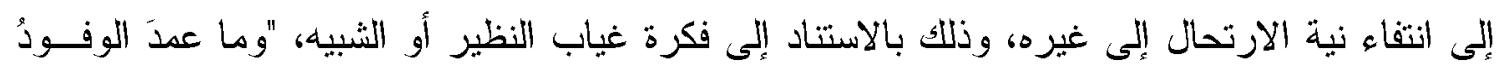

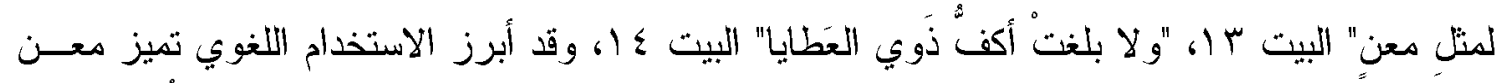

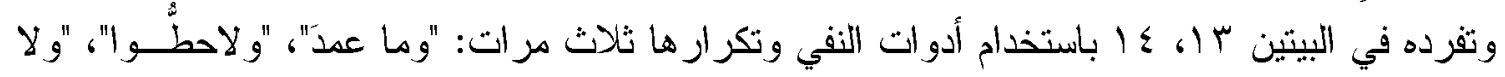

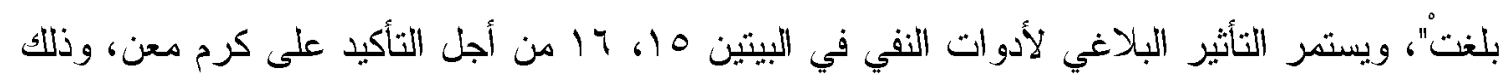

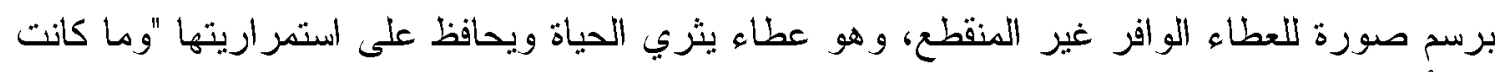

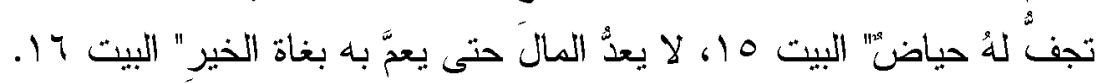

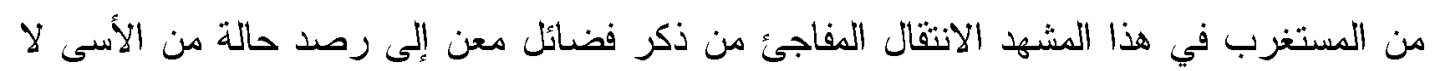

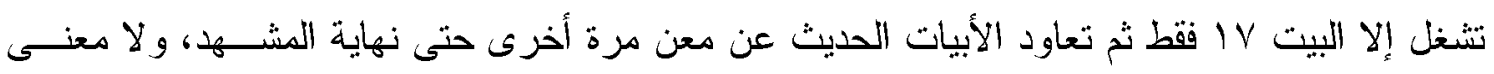

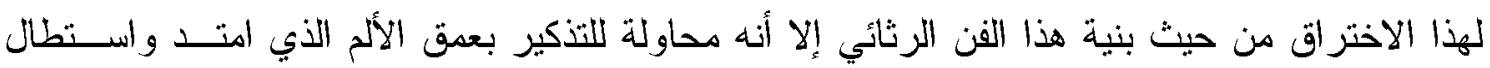

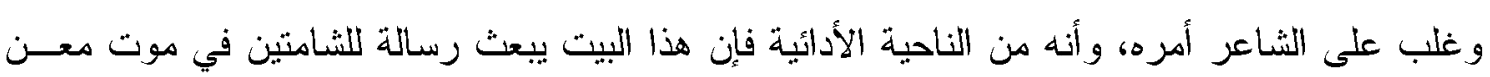

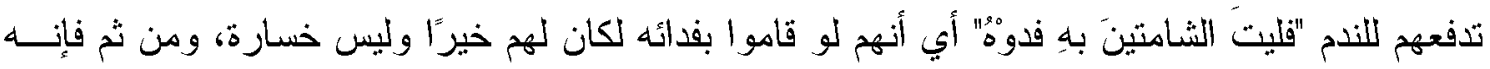

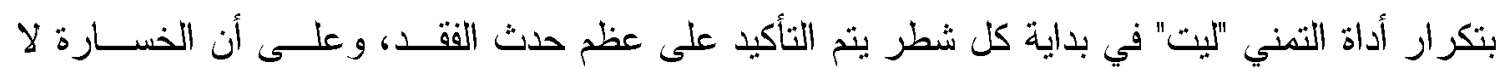

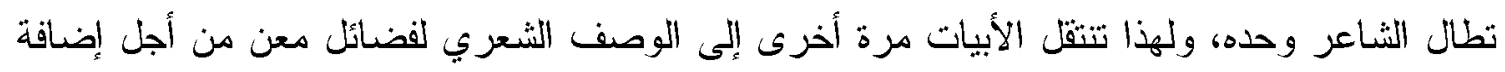

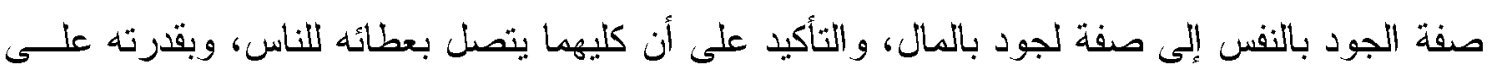
إثثر اء الوجود الإنساني. وردت عبارة "لم يكُُ كنزهُ ذهبًا" في البيت 1 ا أتوكد على الوجود الهتميز لإنسان كان كنزه: "سيوف

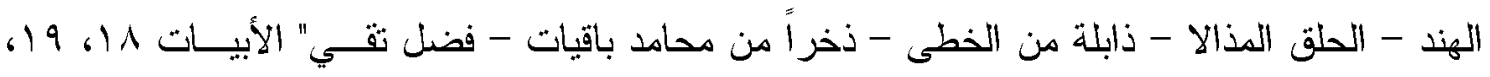

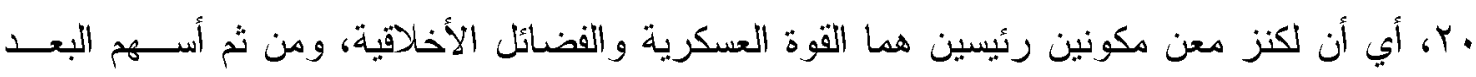

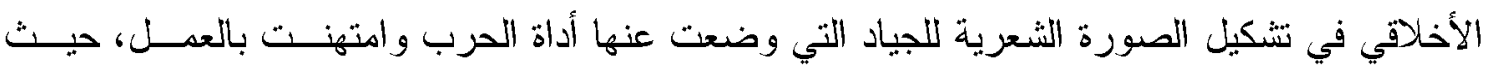

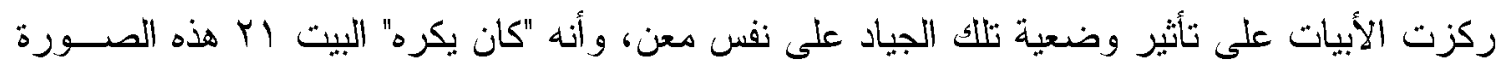

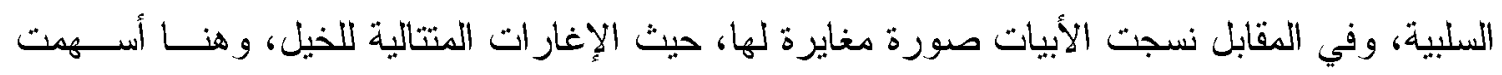

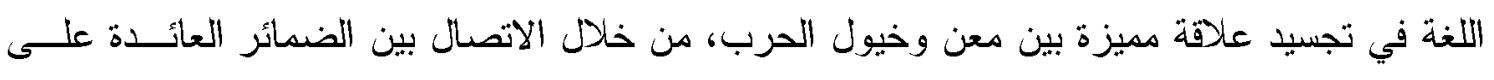

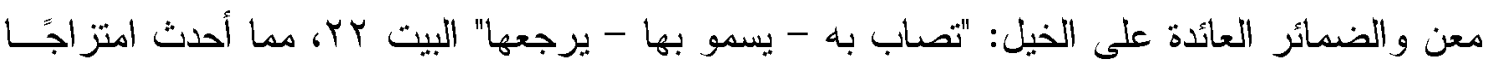

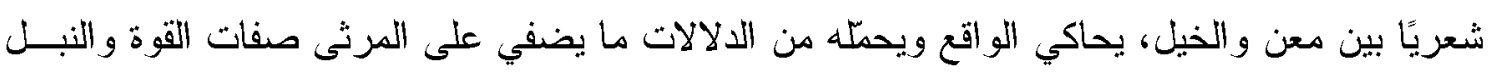
و القروسية.

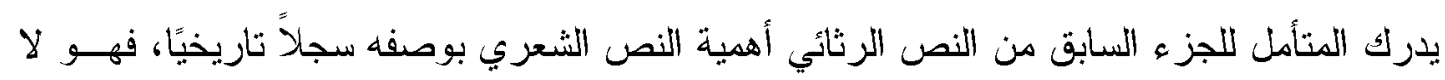

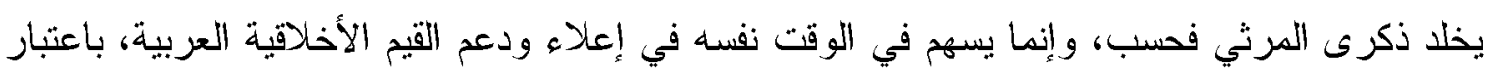


أن فضائل المرثي هي جزء من نظام هذه القير، و عندما تحفظ القصيدة تلك الأسس التي يقوم عليها هـــاء

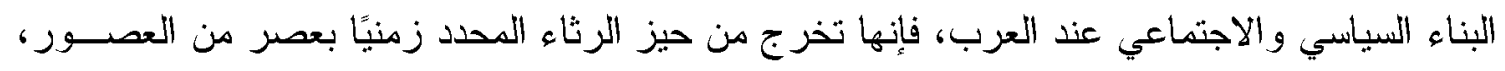
إلى الأفق الثقافي الأرحب والمستمر عبر الزمن.

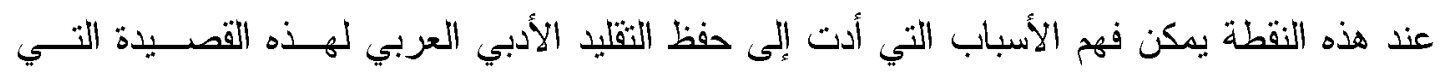

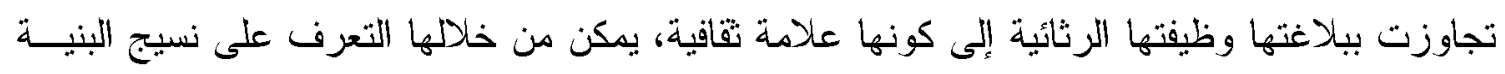

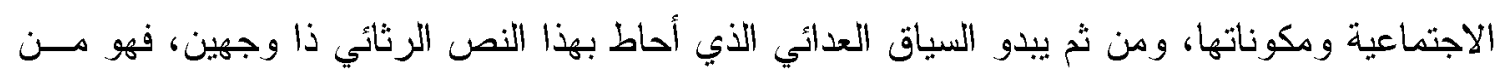

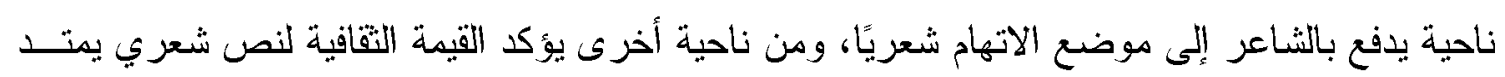

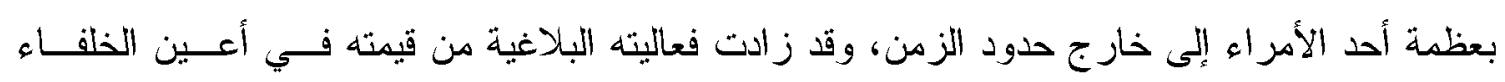
العباسيين.

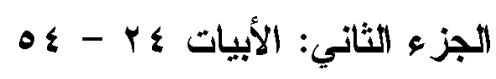

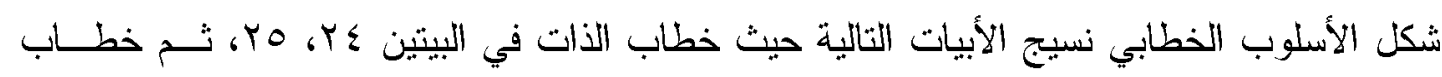

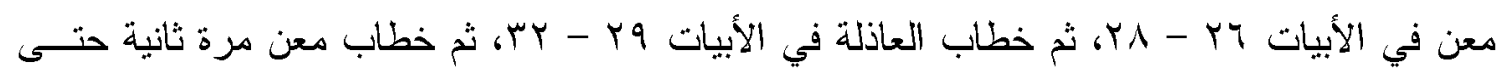

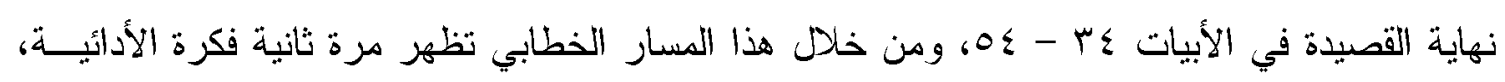

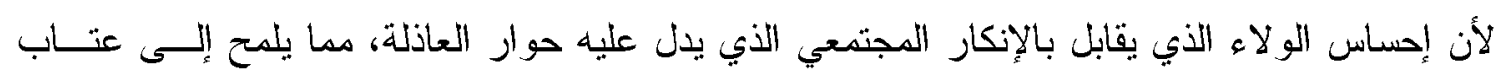

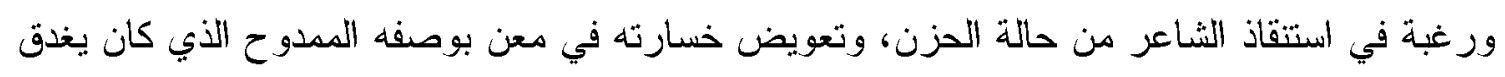
عليه العطاء.

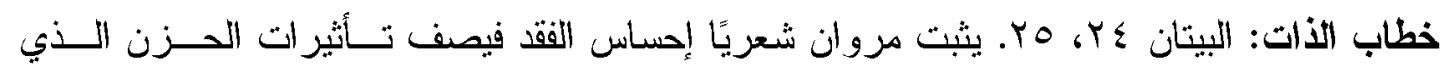

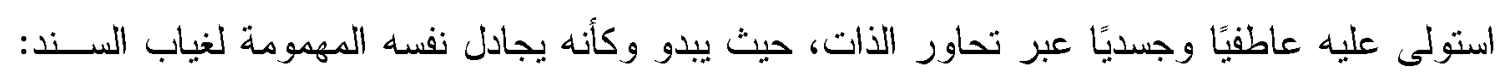

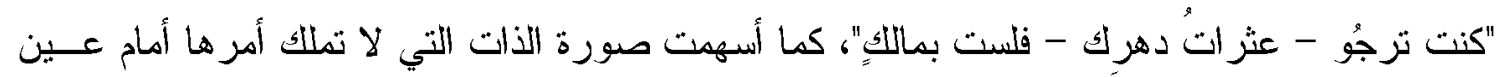

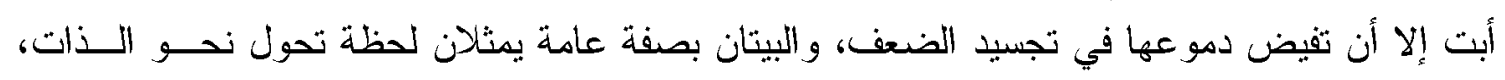
والتوجه إليها بخطاب يعبر أبلغ تعبير عن شعور عميق بالأسى.

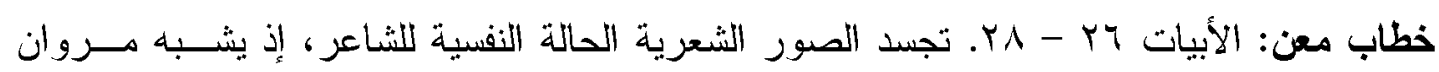

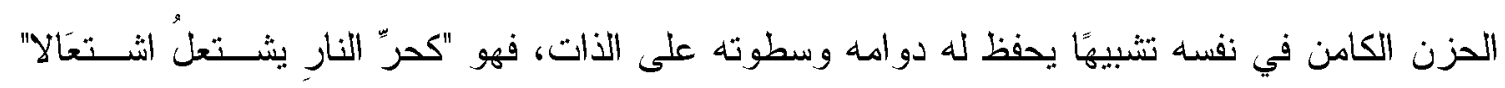

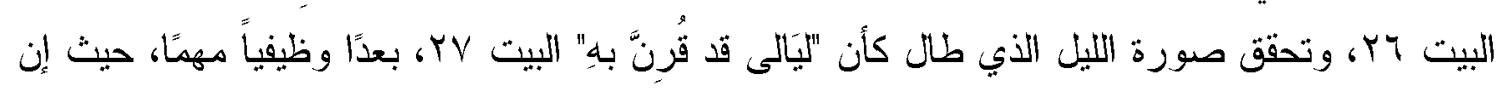

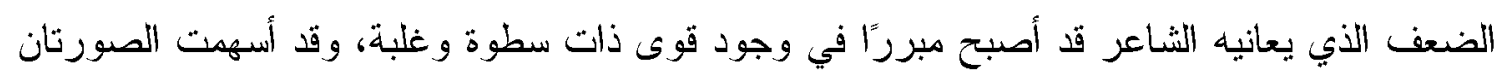

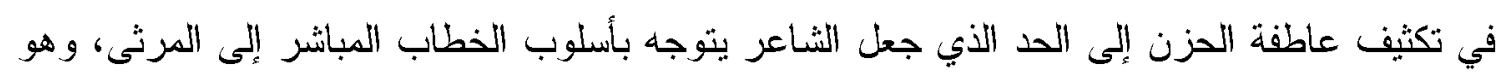

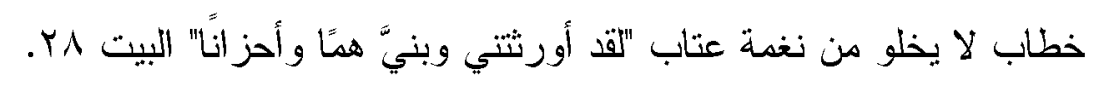

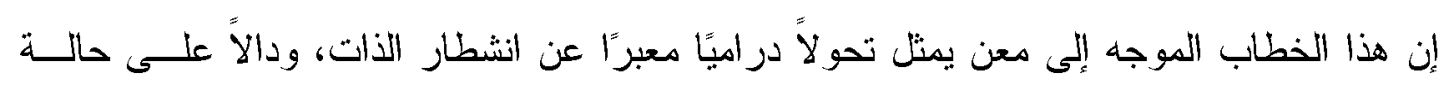

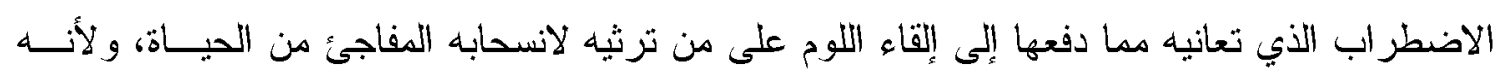

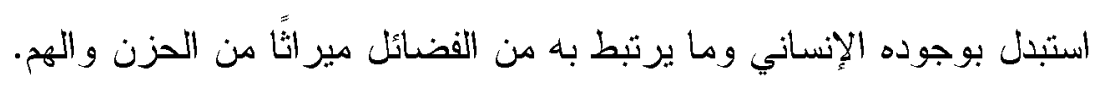




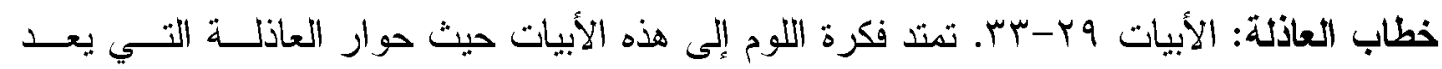

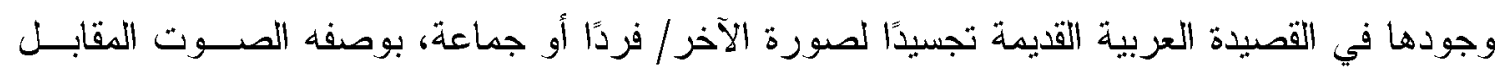

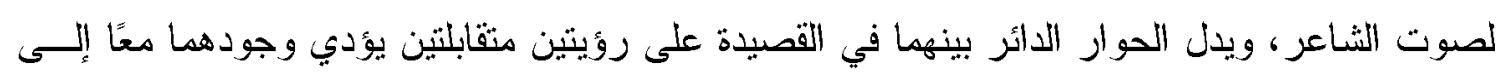

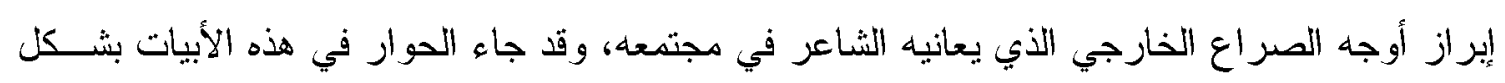

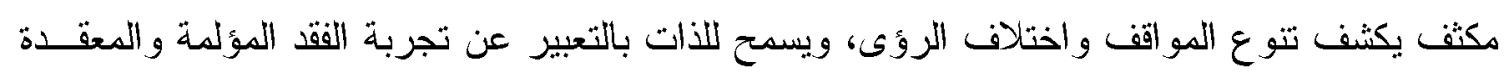
في الوقت نفسـه. من المثير للنأمل أن الأبيات قد عرضت لوم العاذلة عرضًا مؤيداً بالحجج التي يصعب على الثاعر تكذيبها لانها تستند إلى الو اقع الفعلي حيث الرؤية المباشرة لجسده المتهالك، وقد أسند فعل الرؤية إلى بـى

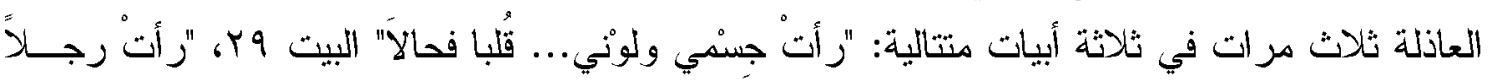

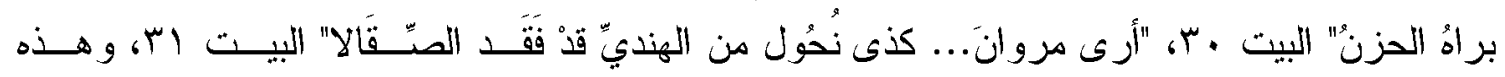
الصور البصرية التي تعد ذريعة للوم العاذلة تحمل دلالة الحزن الثــديد المفضــي إلــى هـــا التغيـر الجسدي، ومن ثم يبادر الثاعر بطرح مقولته الدالة على أن حزنه يتجاوز الظـاهر الذي أنكرته العاذلـــة:

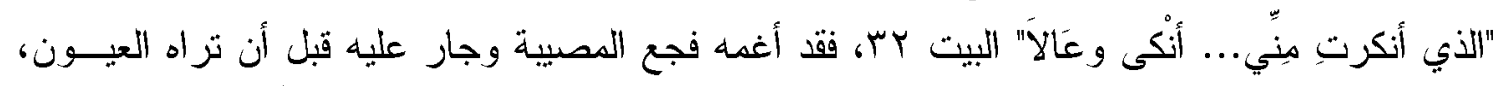

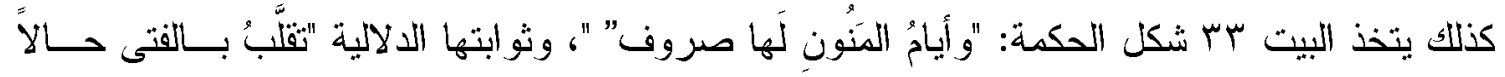
فحالَ"ا، لينبئ عن طبيعة الزمان حيث التغير والتقلب وعدم الثبات على حال، و هنا إلماح إلى المحنة التي يعانيها الثاعر.

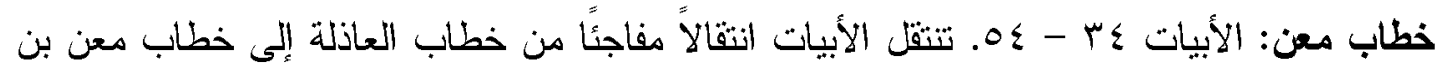
زائدة/المرثي، وهذا التحول الأسلوبي يوحي بإحساس الثاعر بالعجز، وبالانهيار النفسـي، وبانقطــاع

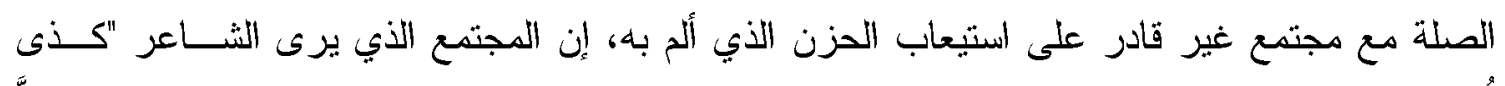

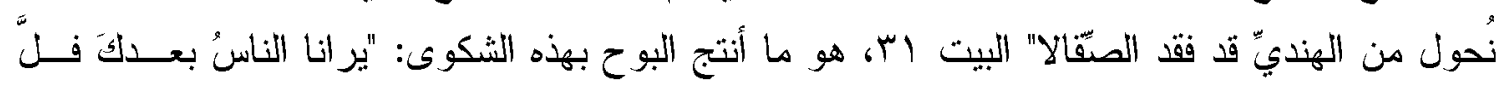

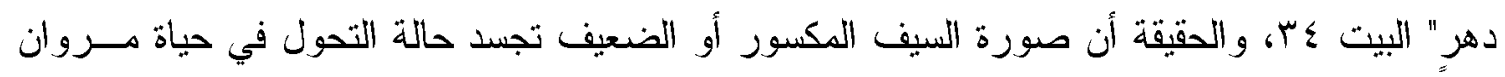

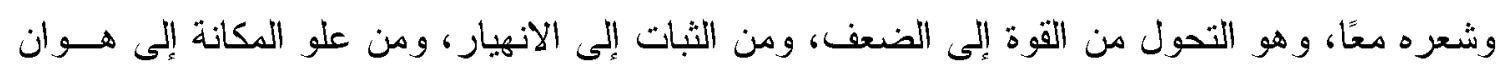

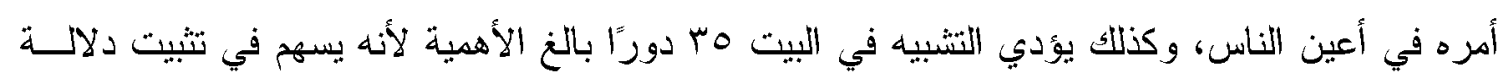

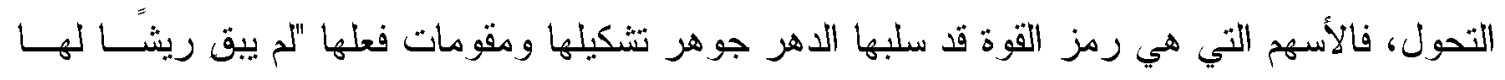

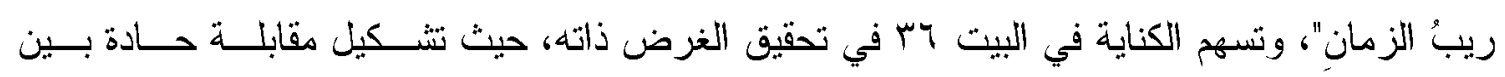

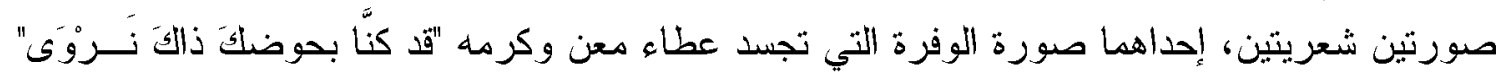

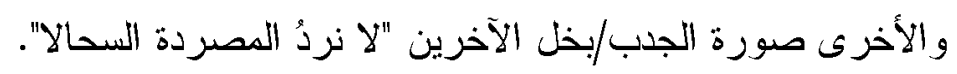

لا تقتصر تلك الصور الثعرية على مجرد تأكيد المعنى، فقد وردت في هذا الموضع من القصــيدة

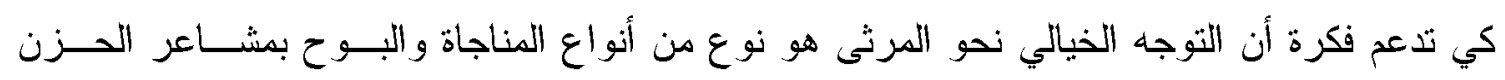

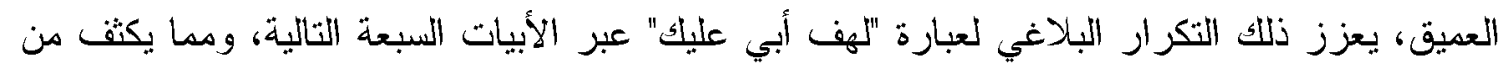

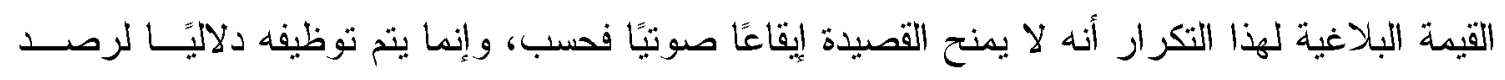


مظاهر التحول من الخصب و الغنى إلى الجدب و الفقر، وهنا انتقال من الحديث عن تحول الــذات مــن القوة إلى الضعف، إلى رصد تحو لات تمس جوهر الحياة في المجتمع، فالعطايا تتحـــول إلـى أمنيــات

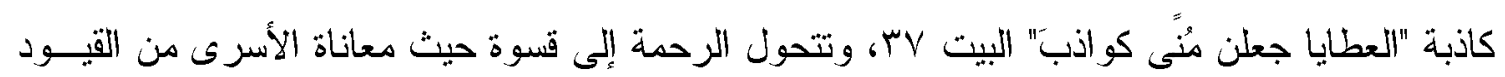

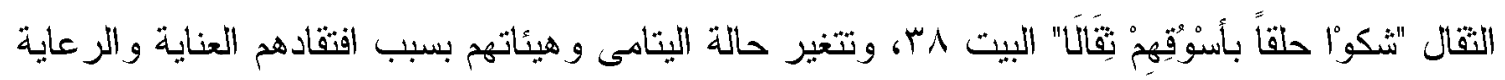

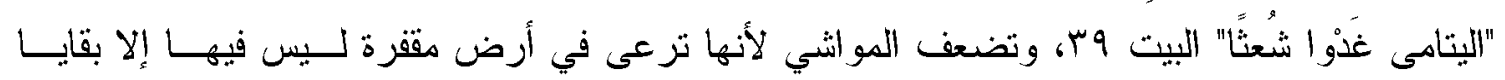
أعشاب يابسة لا تصلح لغذاء ولانيات توفر شبعًا وريًا.

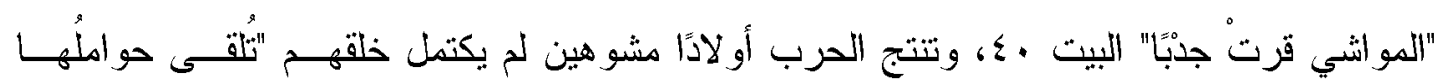

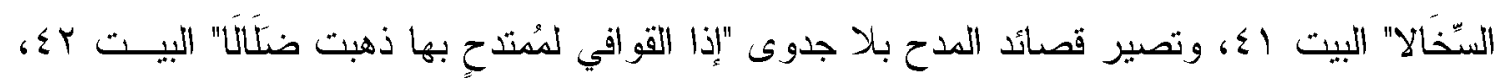

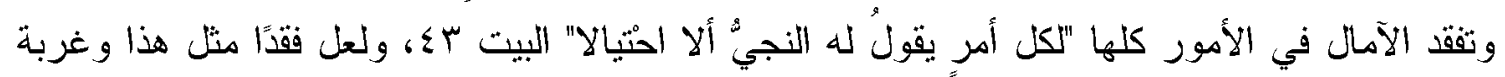

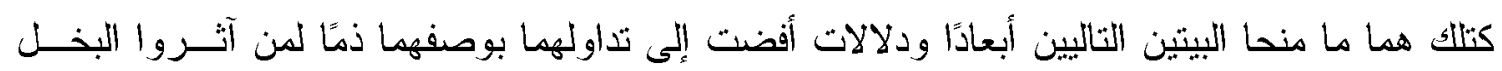
على الكرم، ومن لم تكن ثرواتهم في خدمة أصحاب الحاجات. ؟ لا نُريدُ لَهُ زيالا مُقامـــ

\section{وَتَد ذَهَبَ النَو الُْ فَلا نَوالا}

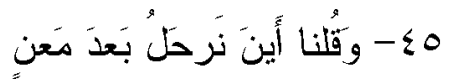

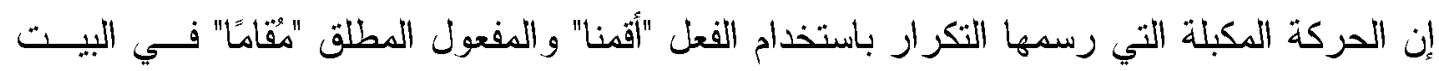

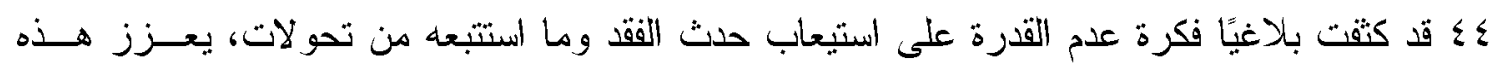

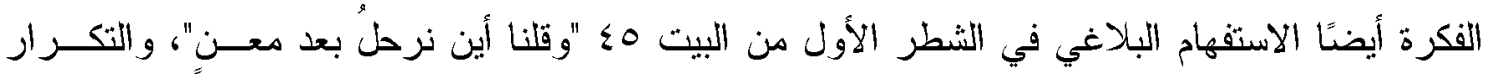

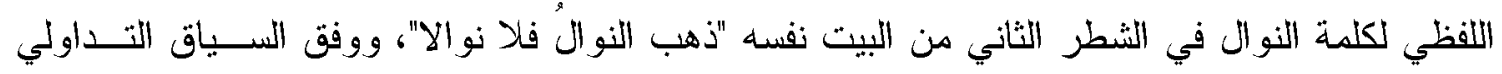

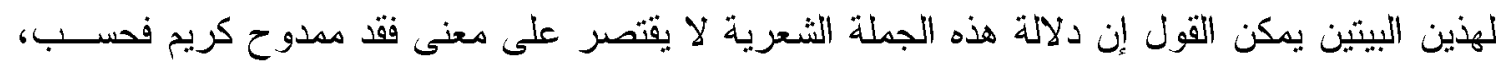

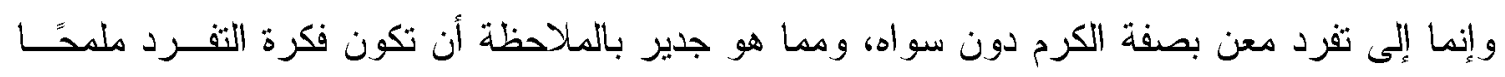
رئيسًا لتشكيل الأبيات التالية.

يبدأ البيت ب؟ء بالفاء العاطفة التي تؤكد أن البيتين السابقين يمثلان خطابًا موجهًا إلى معن وقد عـلا

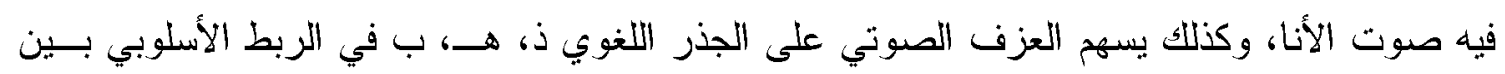
البيت 0 ؛ "وقد ذهب" و هذا البيت "فإن تذهب"، مما يعني استمر ارية الأسلوب الخطابي الذبي يستحضــر

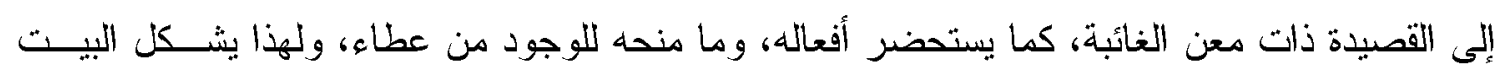

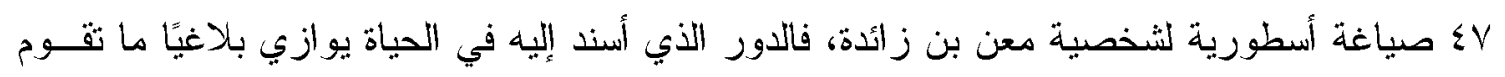

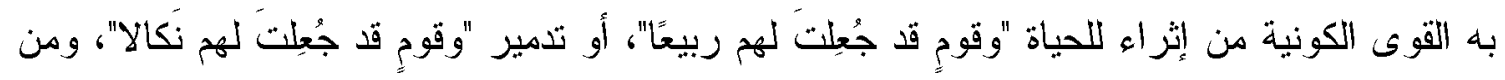

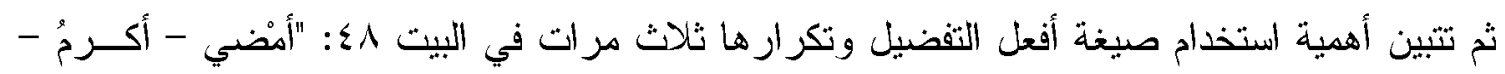
أشدُّ" من أجل التأكيد على المكانة المتفردة لمعن ، تلك المكانة التي لا يضاهيه فيها مثيل أو شبيه. 
يظهر في الأبيات التالية 9؟-10 ملمح جدير بالاهنمام، فقد وضع مروان لقوة معن العسكرية إطارًا

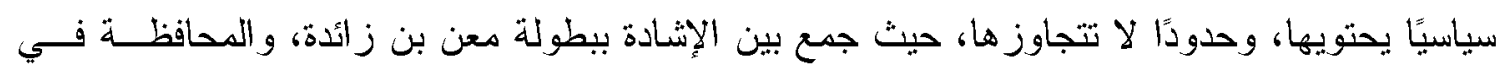
الوقت نفسه على المعايير التي تحدد كيفيات التعامل داخل النظام السياسي، ووفق هذا النظام بعد الخليفة

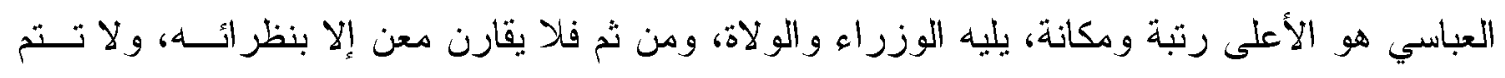

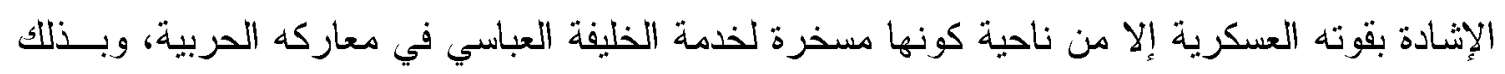
يتضح الفرق بين معن وغيره، فالخليفة سوف يذكر قوة معن عندما يختبر الآخرين في الأمور العظــام

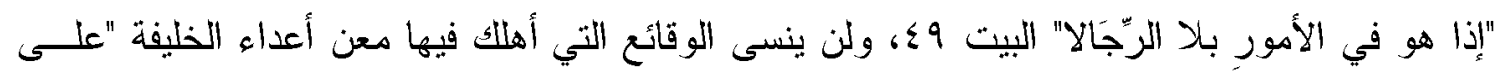

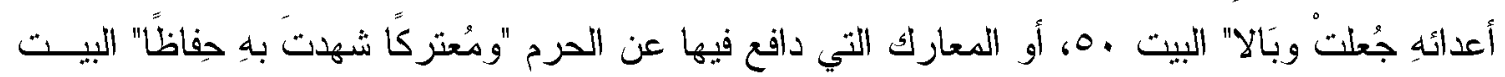

مما يثير الاندهاث بعد قراعة هذا المقطع أن السرد الأدبي قد تجاهل - عمدًا أو بغير عمد - إيــراد

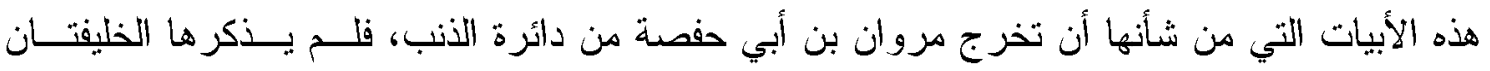

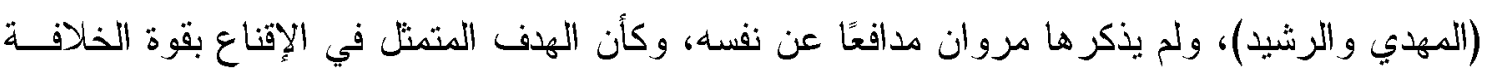

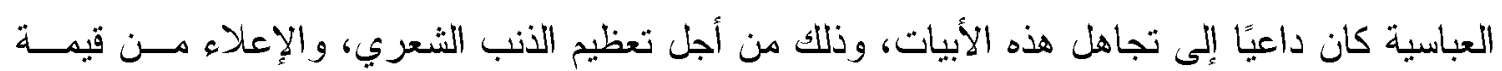
قصائد المدح التي سون تفوم بدور التكفير عن الذنب، واستعادة الهيبة والمكانة العالية للخليفة العباسي. يستعيد مروان في خاتمة القصيدة الجو الحنيني للرثاء مستبدلاً بالخطاب السياسي خطابــاً عاطفيًا.

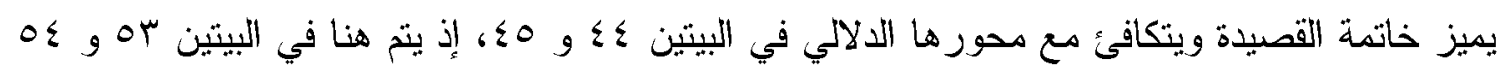

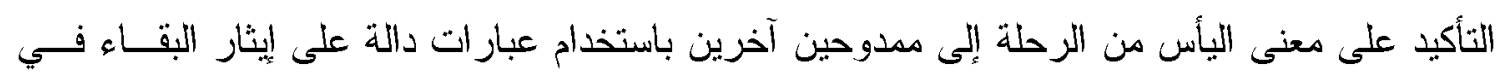

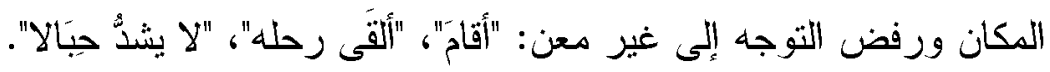

إن قوة البلاغة في هذه القصيدة المثيرة للعو اطف كانت داعيًا لمعاقبة مروان بن أبي حفصة من قبل خلفاء بني العباس، ودافعًا لإنشاء قصائد مدحية تعيد تثكيل البنية المجتمعية حسب هرمية سياسية تحفظ للخليفة العباسي سلطته ومهابته، فقد كان من بين دعائم تأسيس البنية التقافية التي حرص التقليد الأدبـي لتئي على تأكيدها إثبات الهيمنة السياسية للحاكم، ومن ثم كان اختيار القصائد وتفييمها خاضعين بشكل و اضحح

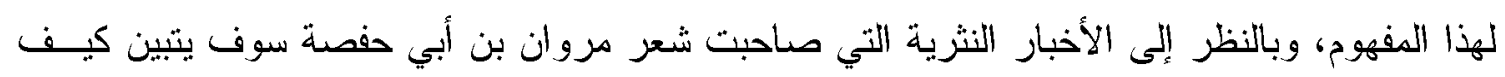

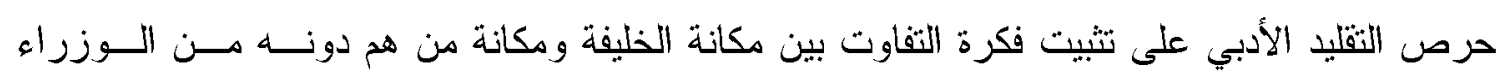

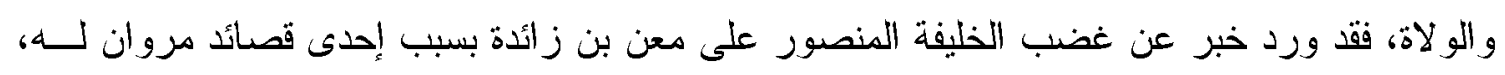

ولأنه كافأ مروان على تلك القصبدة المدحية بألف دينار، ورد الخبر في الأغاني على النحو التالي:

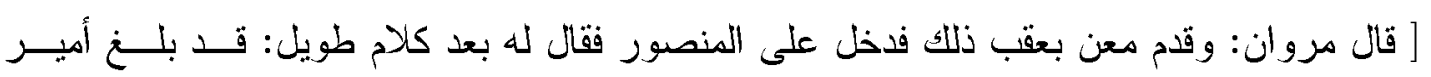

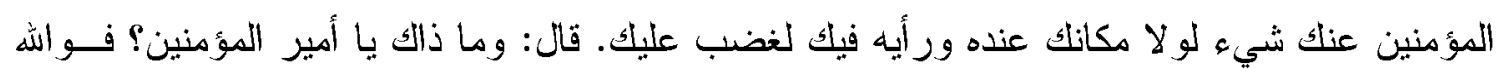
ما تعرضت للك منك، قال : إعطاؤك مروان بن أبي حفصة ألف دينار لقوله فيك:

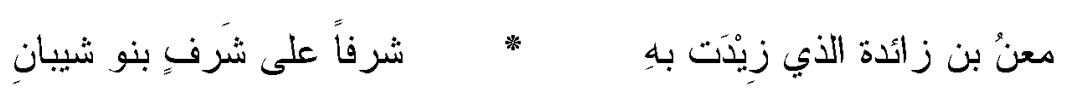




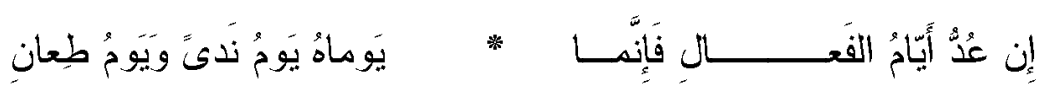
فقال: والله يا أمير المؤمنين ما أعطيته ما بلغلك لهذا الثَعر ، و إنما أعطيته لقوله:

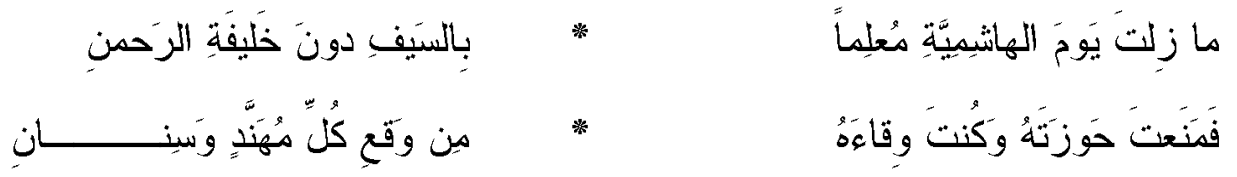

فاستحيا المنصور وقال: إنما أعطيته ما أعطيته لهذا القول؟ قال: نعم يا أميز المؤمنين! والهه لــولا لأل

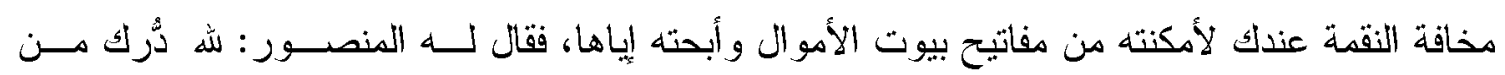

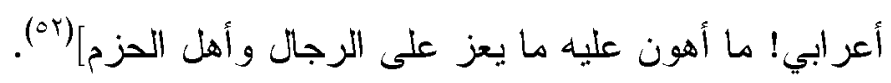

يلقى هذا الخبر مزيدًا من الضوء على علاقة مروان بالسلطة الحاكمة، ويحيط سياق تداول مدائحه| أو مر اثيه لمعن بن زائدة بحالة من الغضب، ففي الخبر السابق يغضب الخليفة المنصور على مروان بن

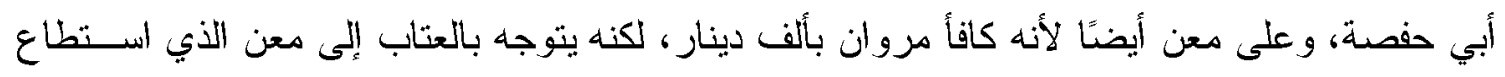

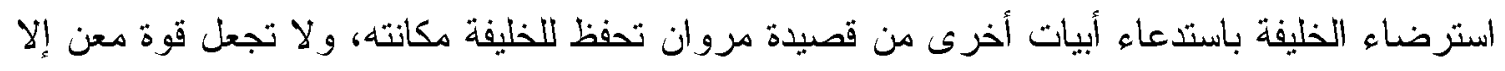
أداة حماية له "فنعت حوزته وكنت وقاهه"، والأمر كذلاء في قصيدة الرثاء، فمن الملاحظ أن الأبيـات

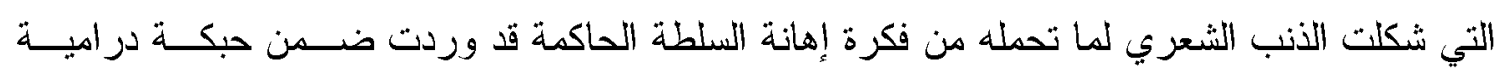
دمجت شعر الذنب وشعر العفو معًا، وبذلك يفترض أن مدائح مروان بن أبي حفصة لخلفاء بني العباس ونس

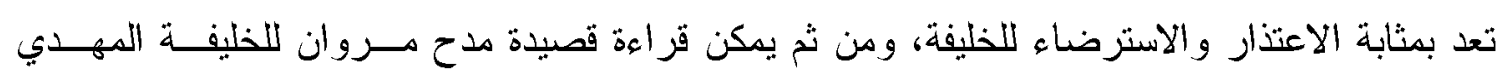

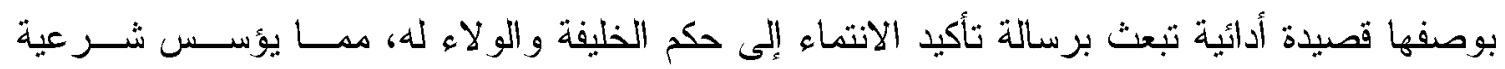
السلطة الحاكمة، و الثاعر أيضًا.

\section{المبحث الثالث}

\section{بنية الاستعادة / قصيدة المدح}

حرص التقليد الأدبي على إبراز السياق التداولي لقصيدة مروان بن أبي حفصة في مــــح الخليفــة

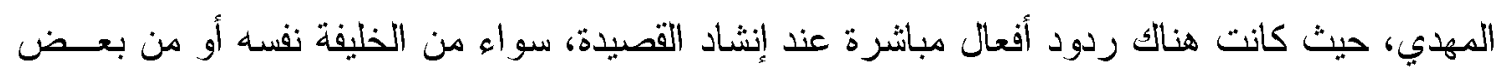

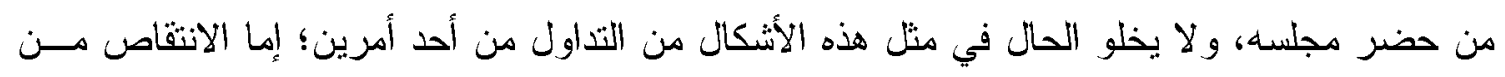

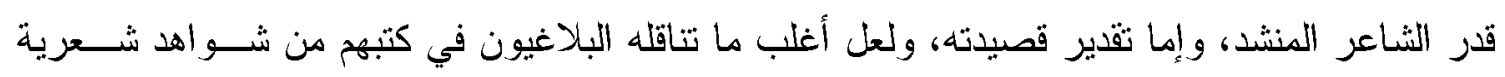

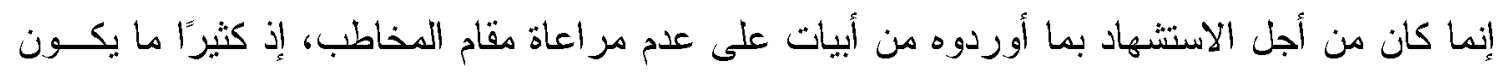

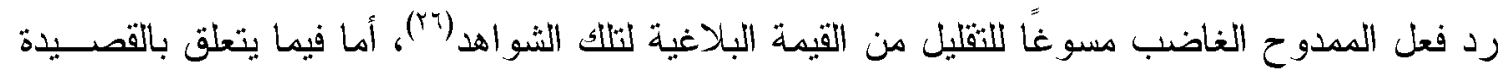

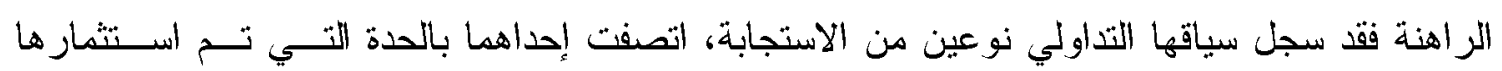
لإعلاء قيمة الثاعر وشعره، ودلت الأخرى على علو القيمة البلاغية للقصيدة بسبب رضـــا المـــدوح وإعجابه بما سمع، وقد ورد الخبر في كتاب الأغاني على النحو التالي: 
] اجتمع مروان بن أبي حفصة و أبو محمد اليزيدي عند المهدي، فابتدأ مروان ينشد: طرقتلك زائرةً فحيّ خيالها

فقال البزيدي: لحن والهه وأنا أبو محد. فقال له مروان: يا ضعيف الز أبي أهذا لي يقال! ثم قال:

\section{بيضاءُ تخلط بالجمال دلالها}

فقال له بعض من حضر : با أمبر المؤمنين أيتكنّى في مجلسك! "بعني البزيدي" فقال: اعذروا شيخنا فإن له حُرمةت

يثير التركيب اللغوي الذي استفتح به مروان بن أبي حفصة قصيدته تساؤلاً مهمًا عن مقصد المتكلم

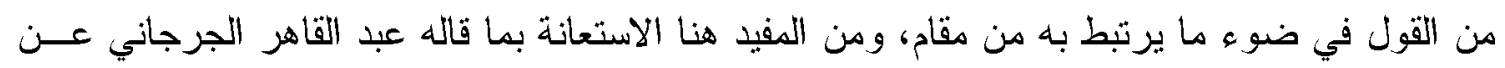

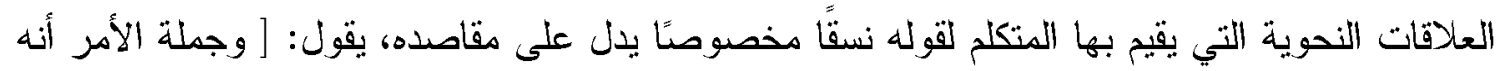

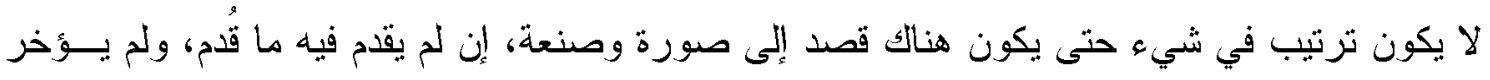

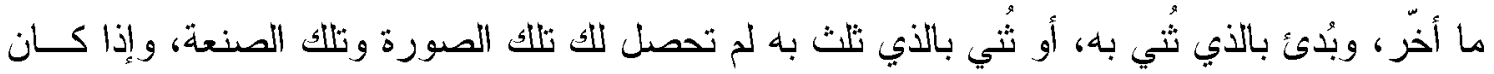

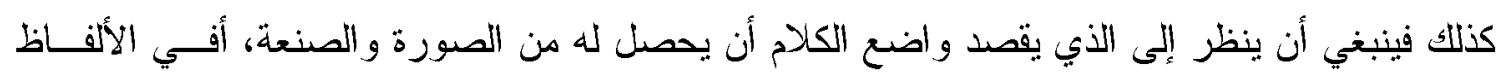

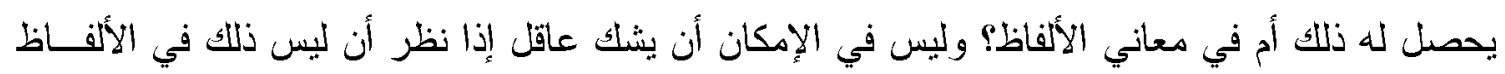

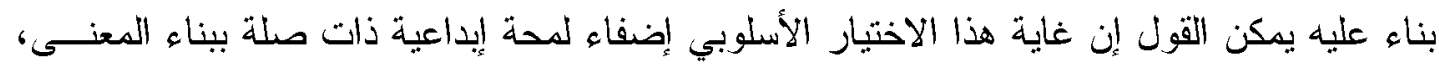

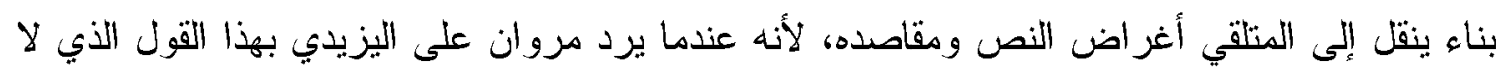

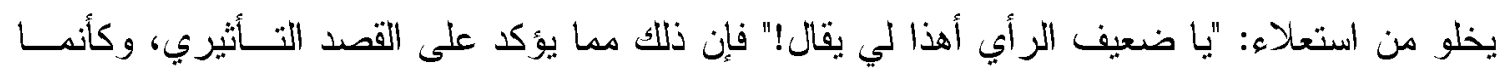

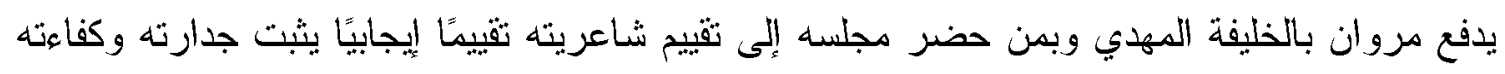

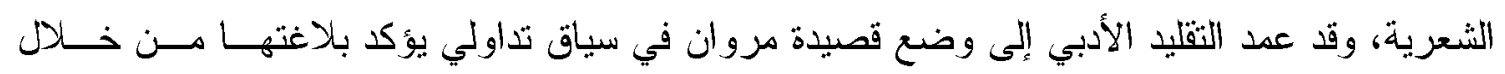

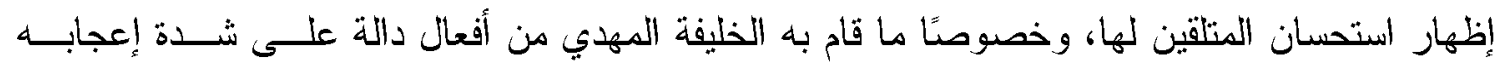

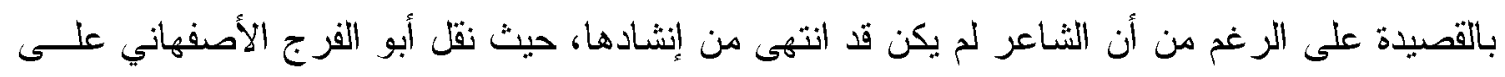

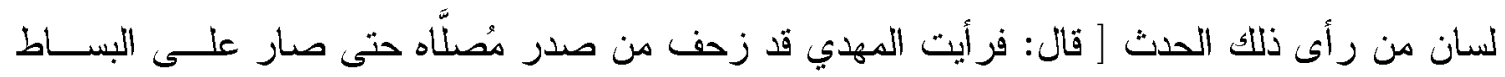

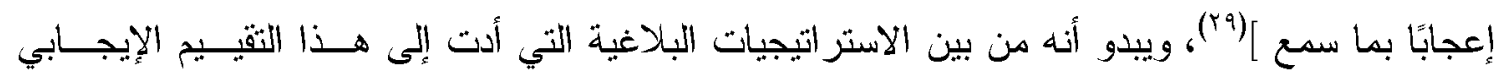

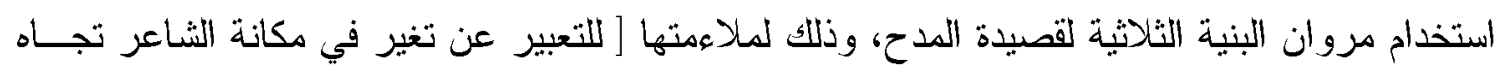

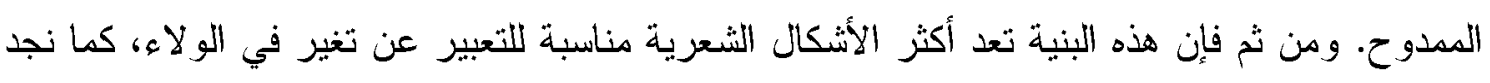

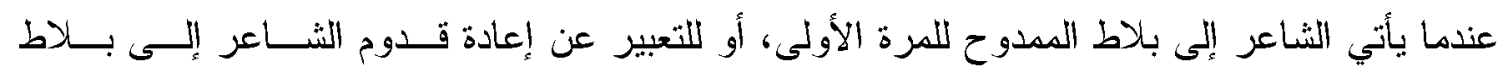

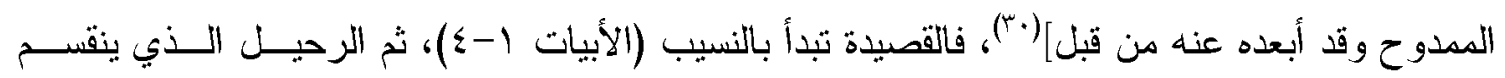

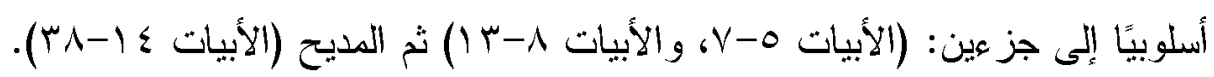


قال مروان بن أبي حفصة يمدح المهدي:(اr) من الكامل

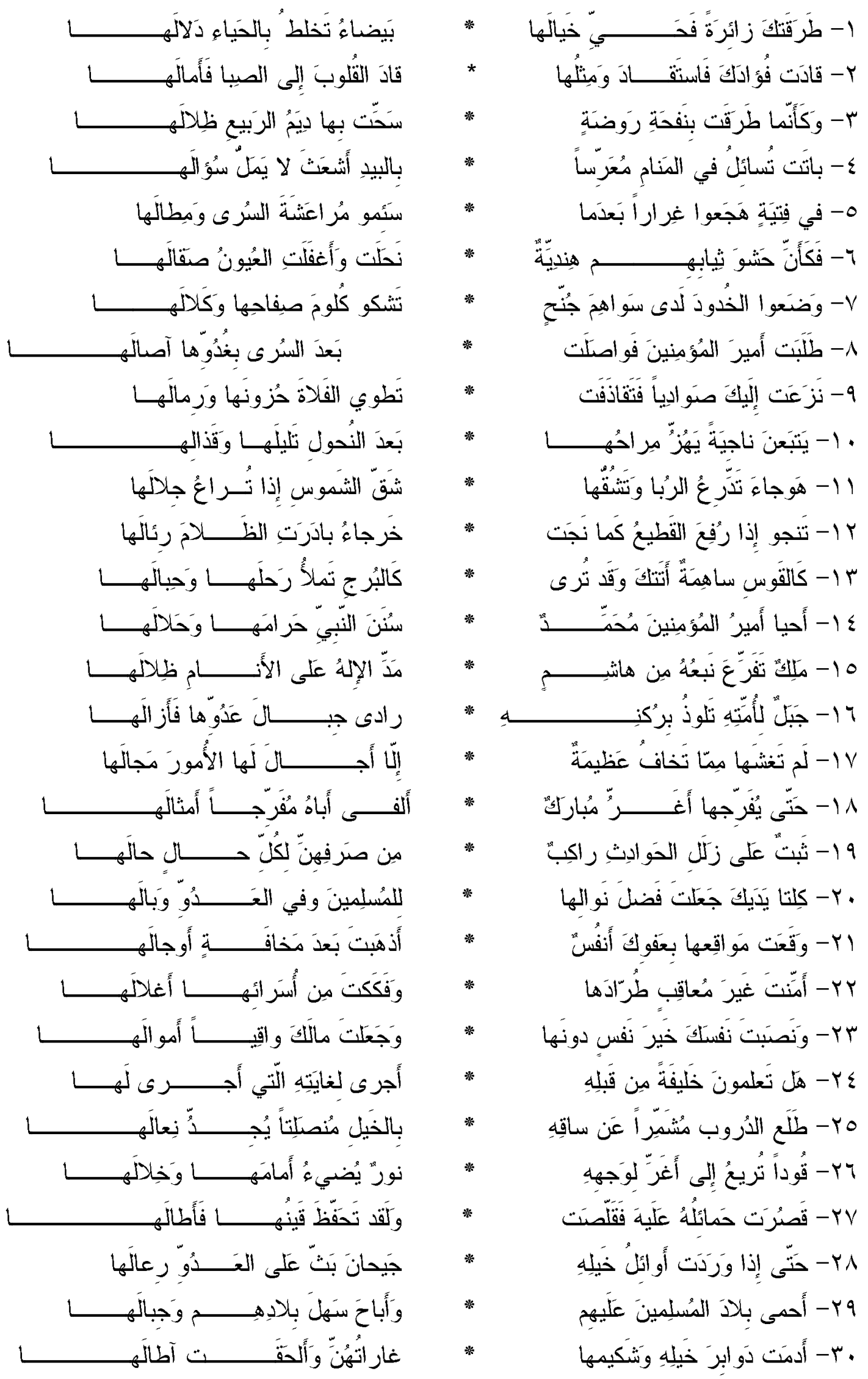




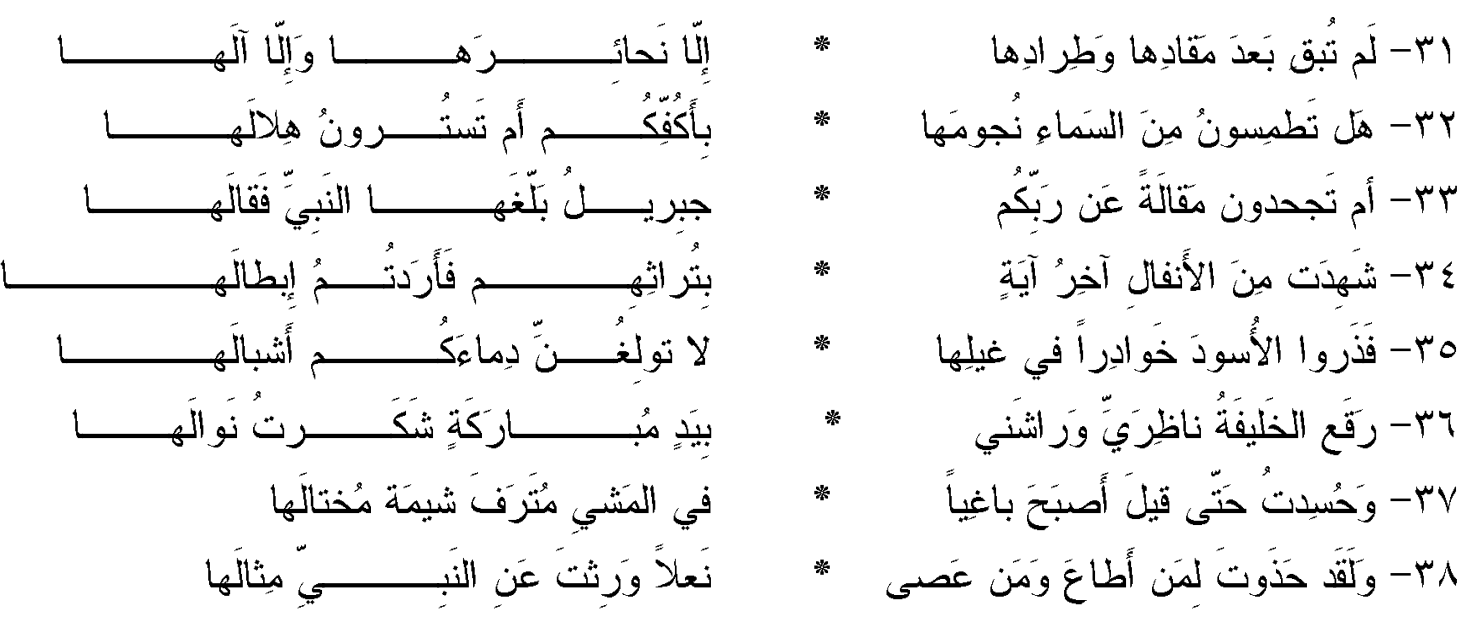

النسيب: الأبيات I - ع. من المهج التعرف على الوسائل البلاغية التي وظف بها مروان بن أبـي حفصة تقاليد النسيب لتصبح جزءًا من تشكيل بنيوي يدعم غرض القصيدة الأدائي، فقد افتـتح مـروبان

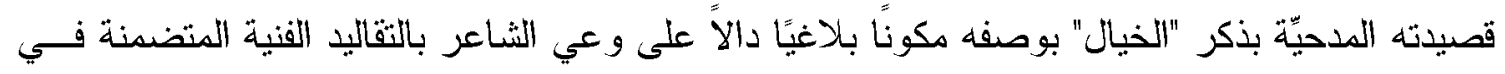

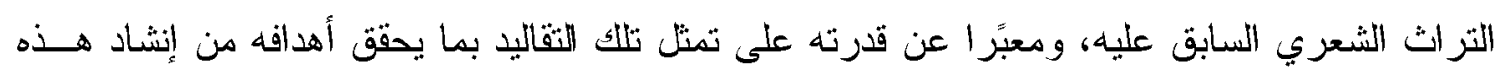

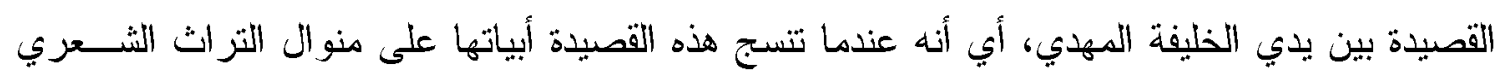

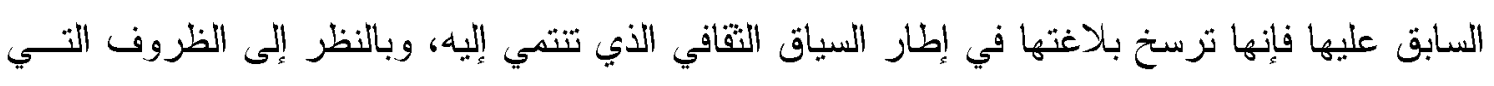

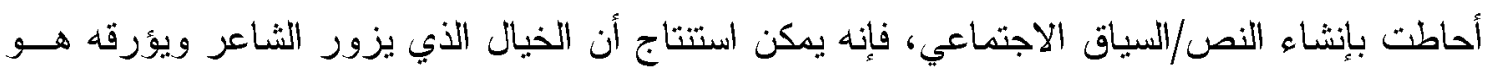

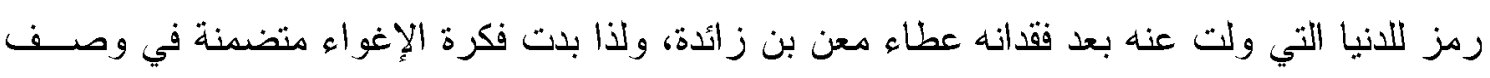

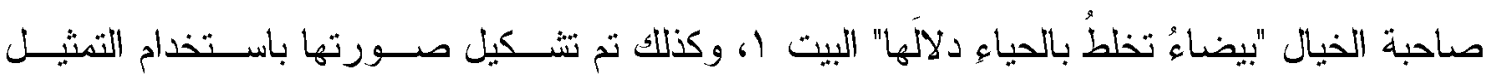

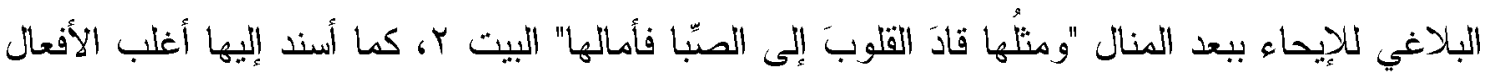

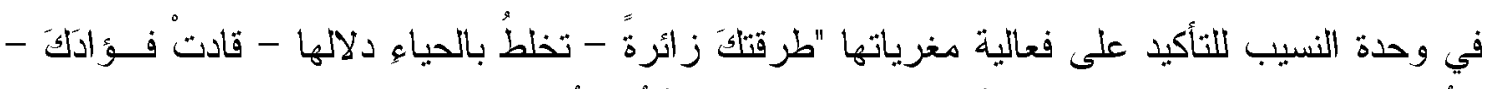

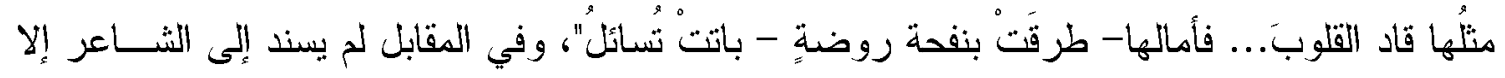

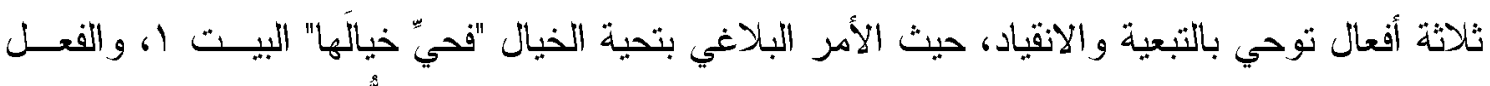

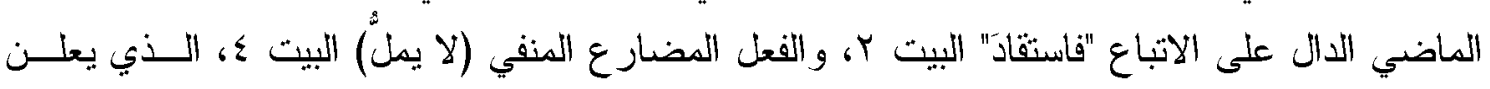
الثاعر بو اسطته عن رغبته في استمرار وقوعه تحت الثعور بالثشوق إلى الخيال الزائر. يهدف مروان في هذه الأبيات إلى استيعاب صورة الخيال في بنية ذات أصداء رمزية تعزز فكـرة

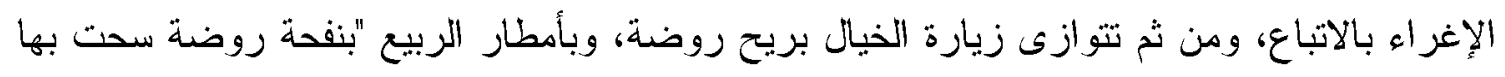

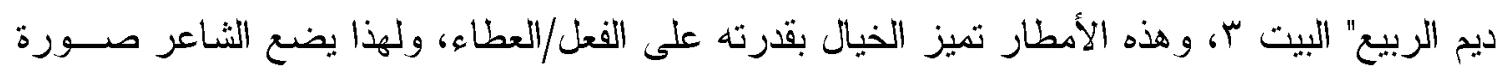

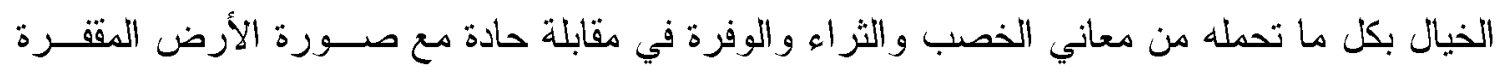

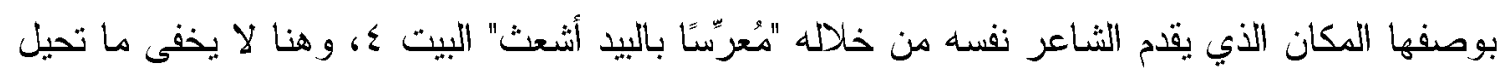

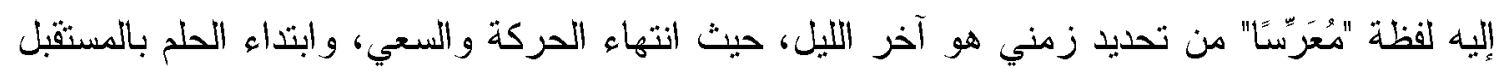

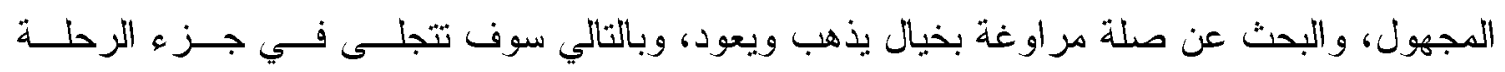


محاو لات الذات الثاعرة للخروج من أسر السلبية والقبض على الحركة الزمانية بامتداداتها، وذلك مــن خلال حركة الناقة وسعيها الحثيث للوصول إلى غايتها.

إن قراءة معاني النسيب في ضوء السرد الأدبي المصاحب لنظم القصيدة يدعم تتاول صورة الخيال بوصفها مجازًا للانيا المدبزة عن الشاعز، ويصبر الاعتر اف بالضعف والعجز أمام مغرياتهــا تمهيـدًا

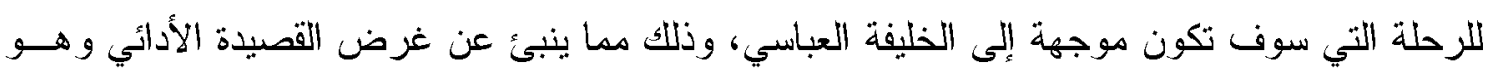
العفو عن الثاعر، وتعويضده عن فقد معن بعطاء يحقق طموحاته المادية.

$$
\text { جزء الرحيل: (الأبيات ه - V) و (الأبيات } 1 \text { - ب ا) }
$$

يبدأ قسم الرحيل بداية جاذبة للاهتمام، حيث يدل الاستخدام اللغوي للجار و المجرور في بداية البيت

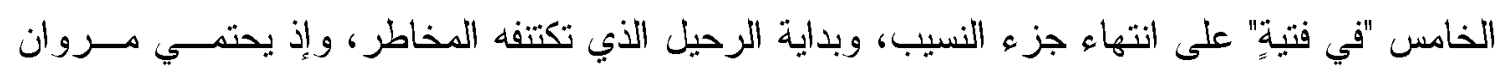

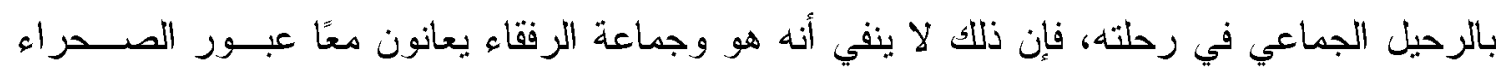

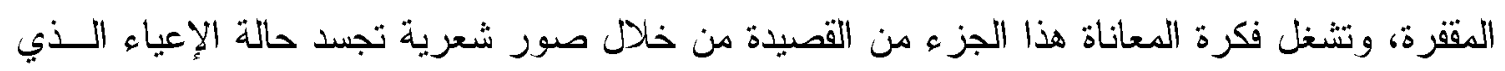

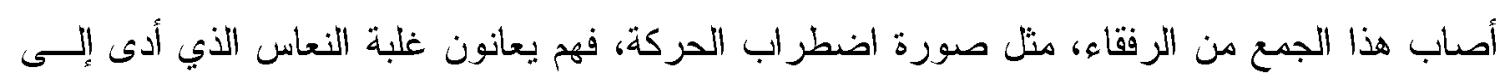

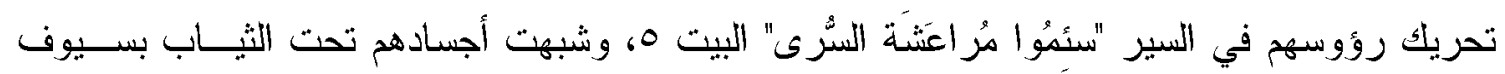

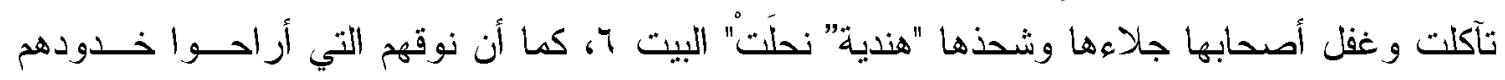

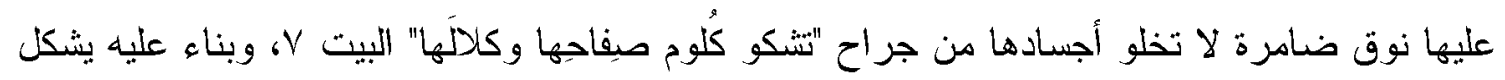
هذا المقطع من قسم الرحبل مؤشرًا دلاليًا بستدل بواسطته على أن ما تتطوي عليه البيداء مــن معانــاة

$$
\begin{aligned}
& \text { يؤكد شدة الحاجة إلى التوجه نحو الممدوح. } \\
& \text { القسم الثاني: الأبيات } 1 \text { - با }
\end{aligned}
$$

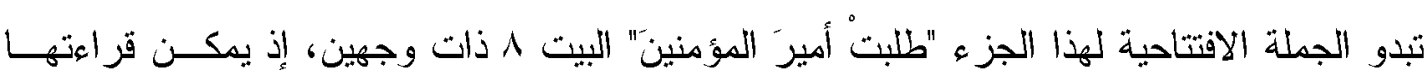

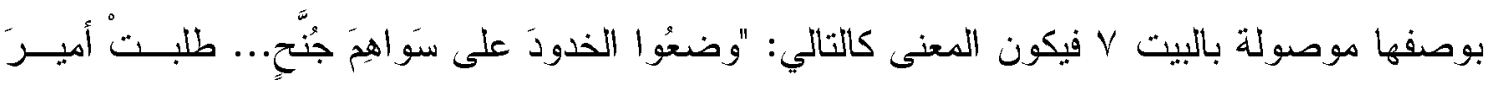

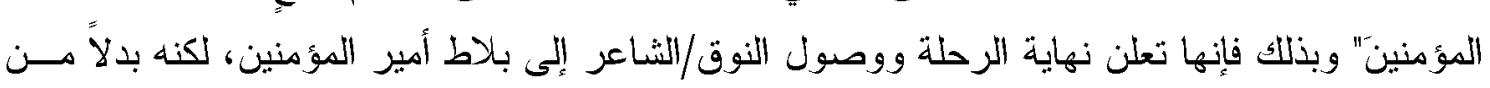

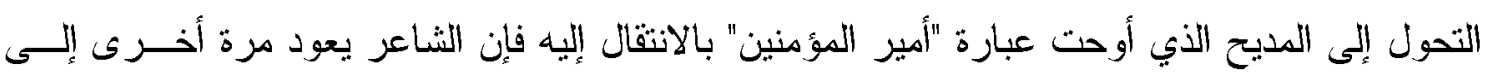

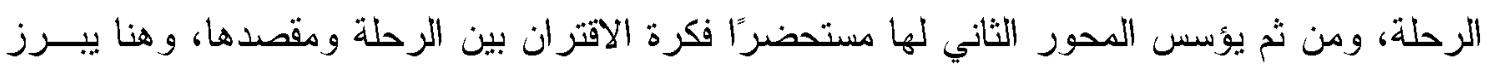

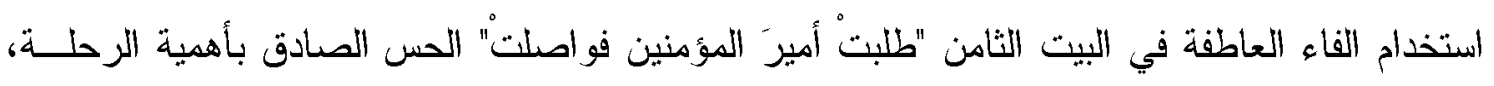
حيث الثقة بكرم الممدوح وفضله، بالإضافة إلى أن الجملة الثعرية في البيت نفسه "فو اصلت بعدَ السرُّى بغُوِّها آصالَها" نقوم بتصوير دقيق للحركة الزمنية بامتداداتها، فالحركة الائبة من النوقَ نحو المدهـدوح

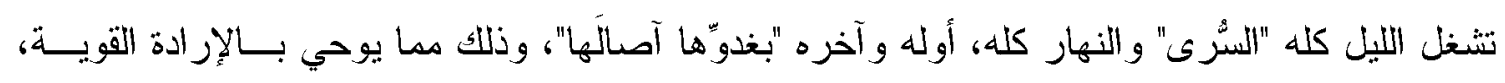

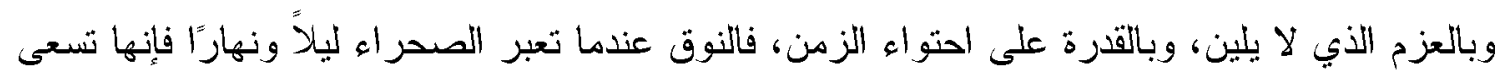

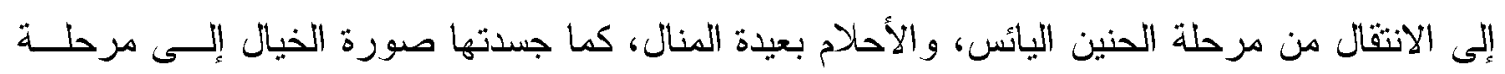

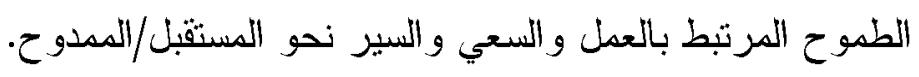


تتصل في هذا المقطع الحركة الدائبة للنوق على المستوى الزمني بحركتها الدائبة علـى المســتوى

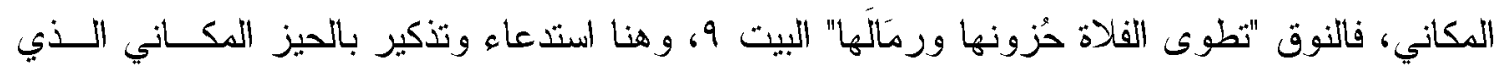

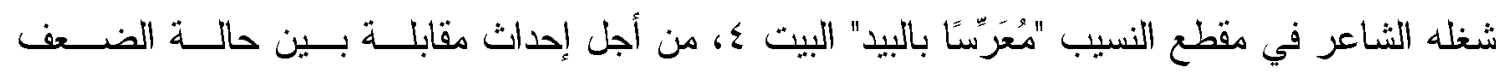

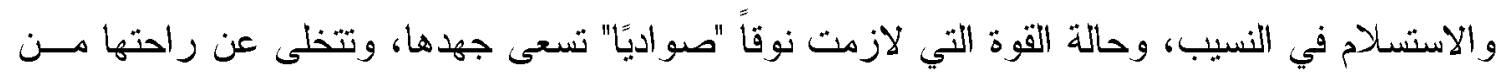
أجل استكمال الرحلة والوصول إلى غايتها. ينتقل الثاعر انتقالاً مفاجيًا إلى وصف ناقته التي من المفترض وجودها ضمنيًا في الأبيات السابقة،

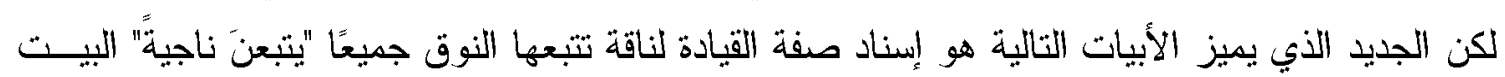

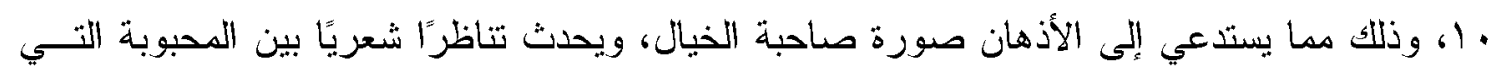

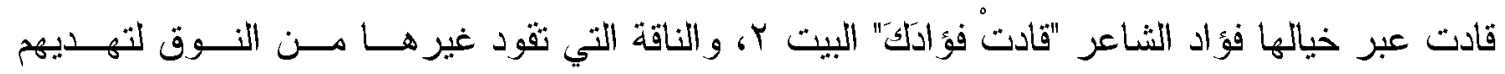

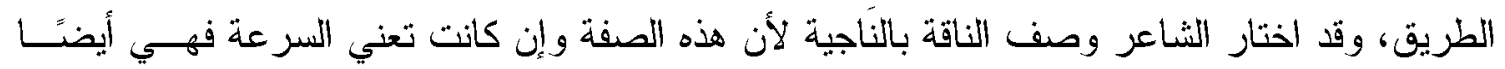

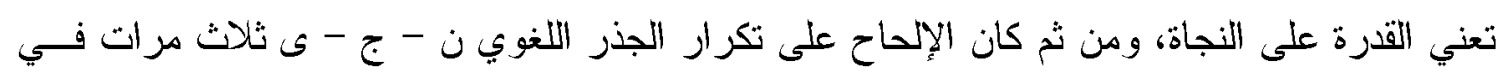

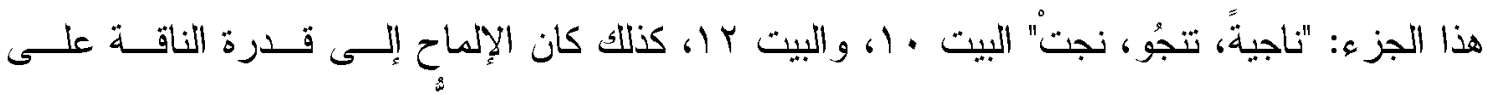

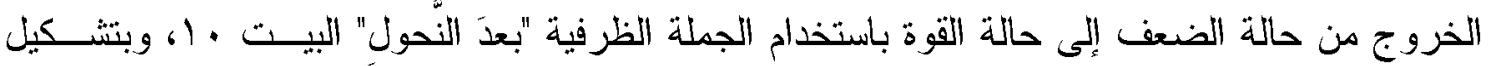

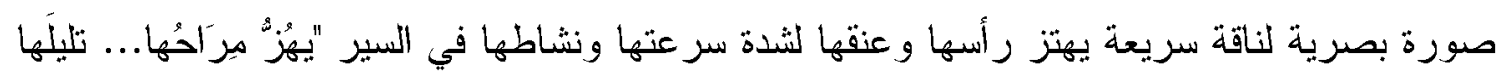

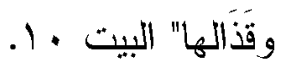

من الناحية اللالالية يشير عبور الشاعر الصحر اء على ناقة لها صفة القيادة إلىى أنـــــ بمضــي مــن

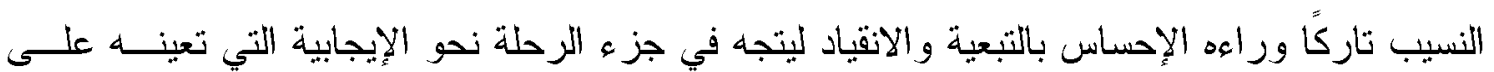

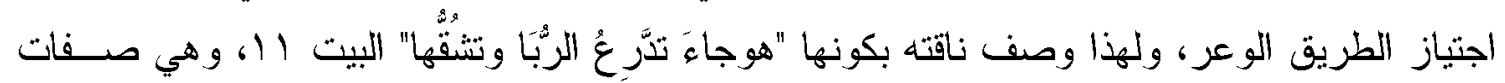

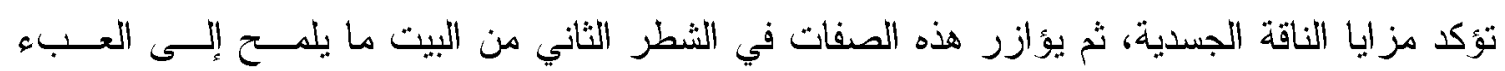

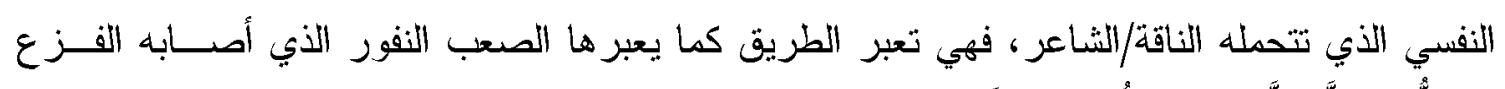

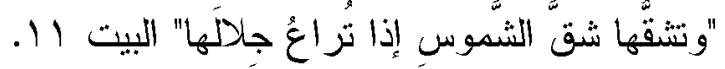

لعل الإشارة إلى رهافة التشكيل اللغوب لصورة الناقة تصبح أمرًا مهمًا في هــذا الســياق، حيــث

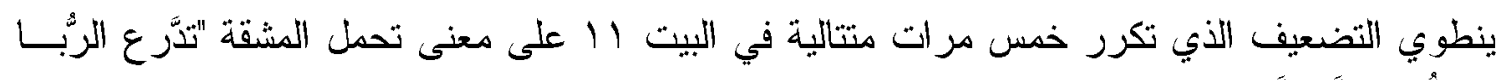

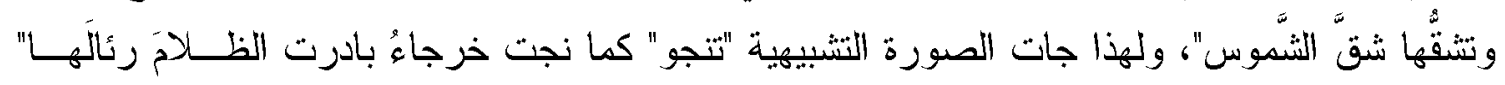

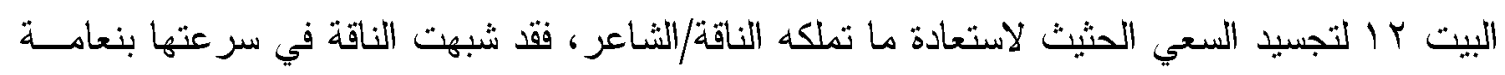

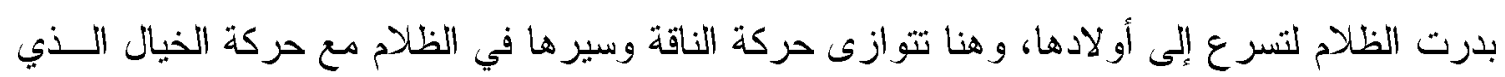

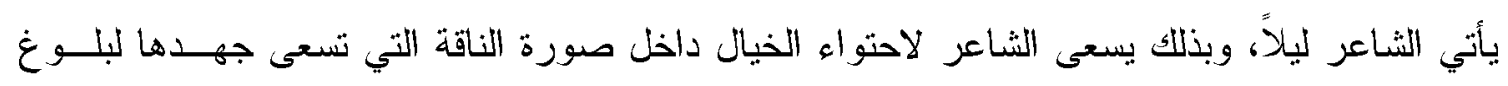

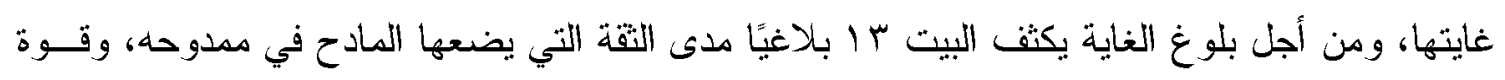
اليقين بإحسانه وكرمه.

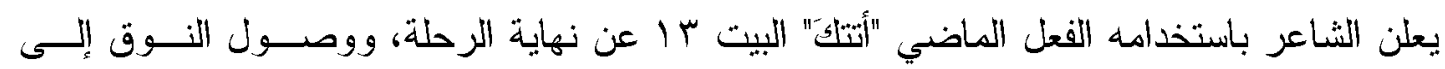
ساحة قصر الخليفة، ويأتي بصورتين تشبيهيتين تكثفان هدف الرحلة وغايتها، في الصورة الأولى يشبه 


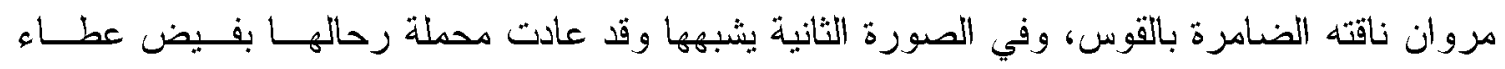

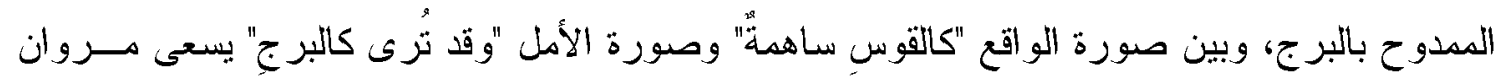
إلى التأكيد على كرم الخليفة ومكانته العالية.

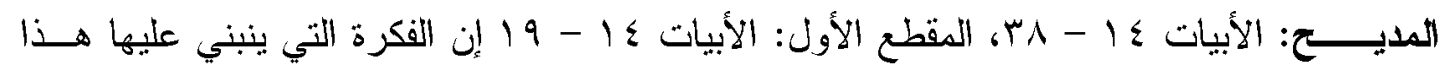

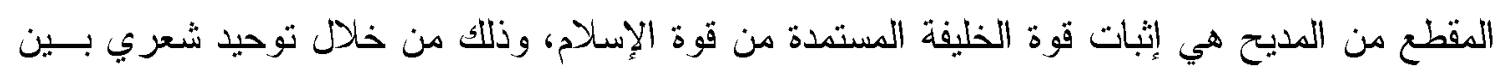

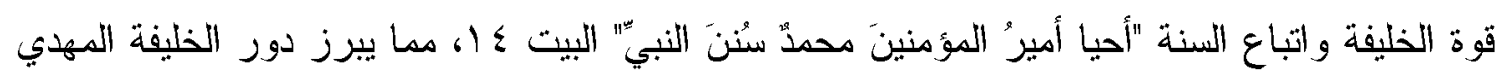

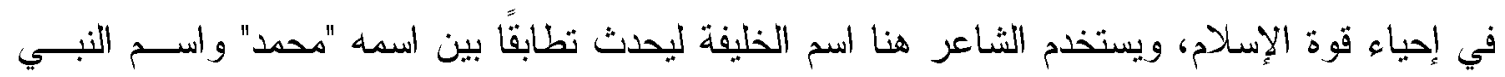

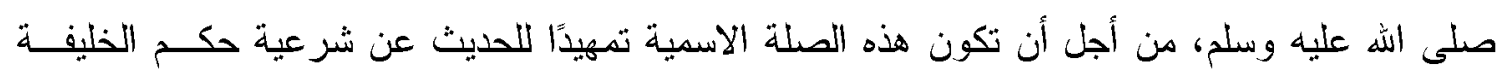

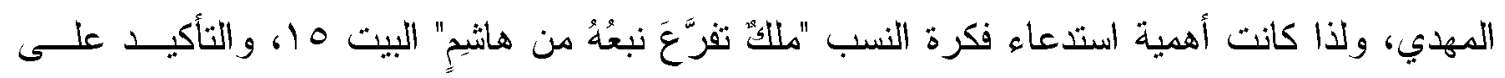

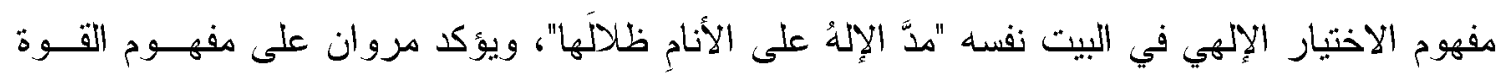

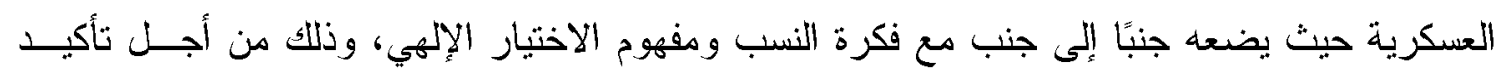

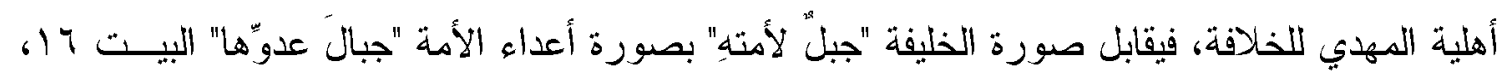

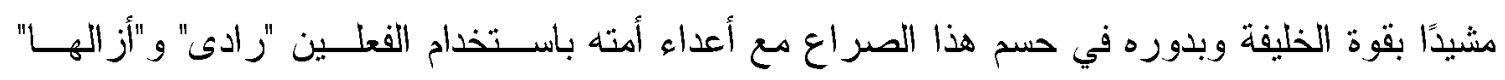
الالين على إفناء جبال العدو /قوته.

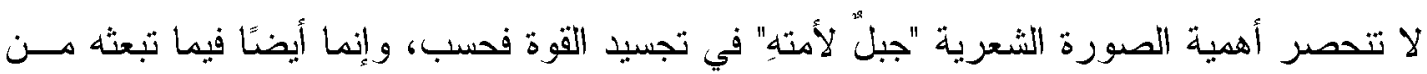

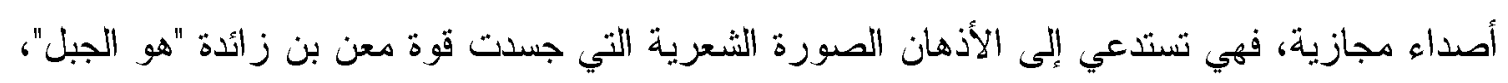

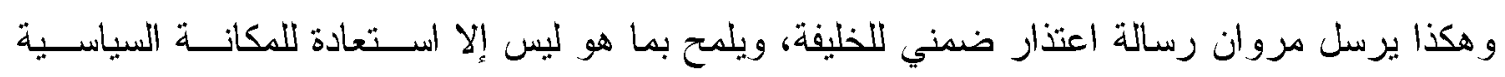

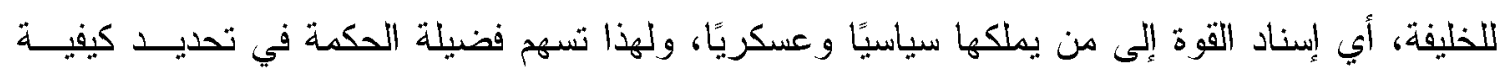

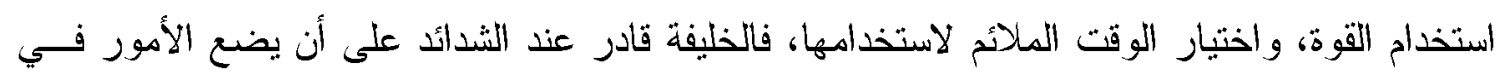

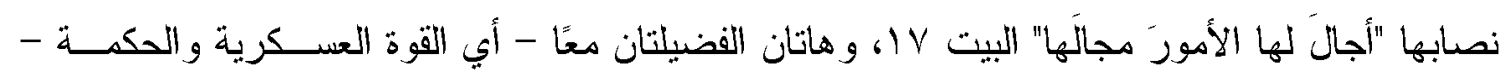

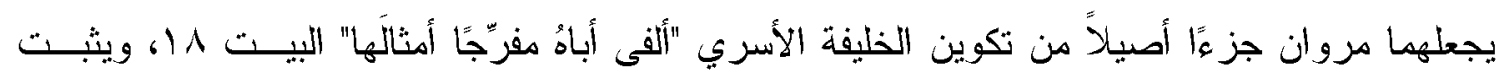

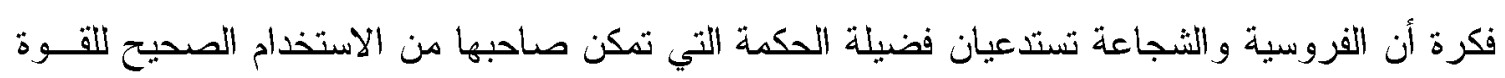

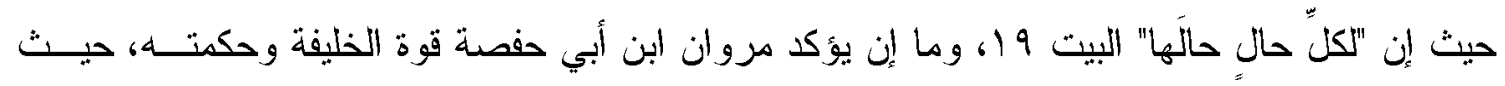

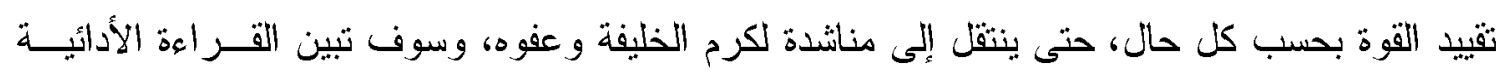

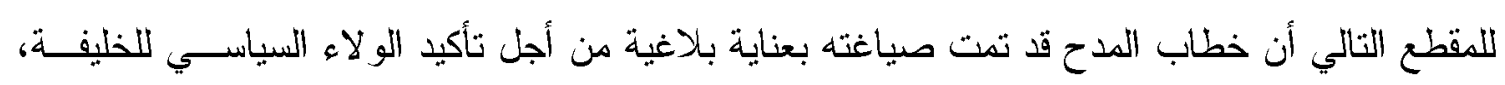
ومن ثم التفاوض حول منزلة الثاعر ومكانته.

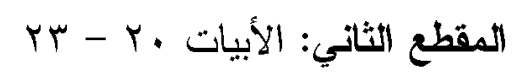

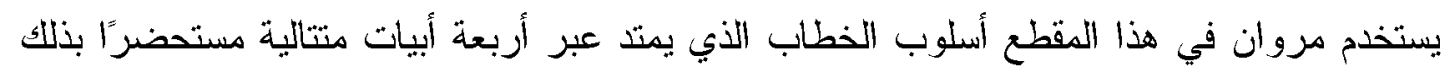

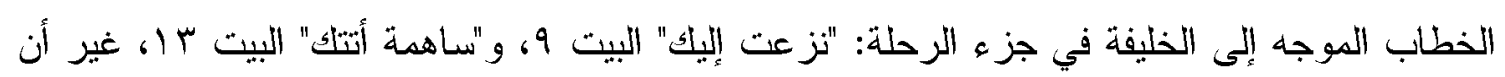

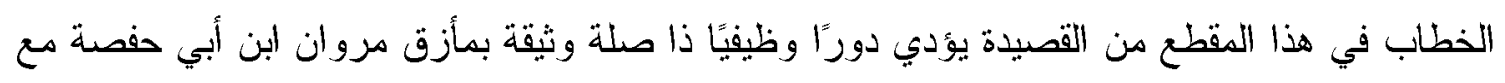

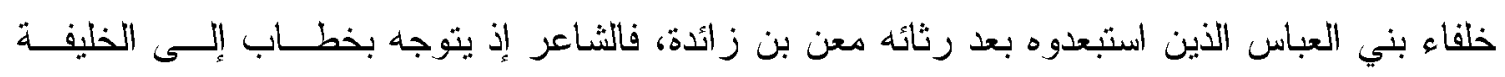


المهدي يقر له فيه بكرمه المفرط، فإنه يبدو حريصًا على اختيار لفظة النو ال دون غيرها من منز ادفات كالعطاء أو الجود أو غير هما:

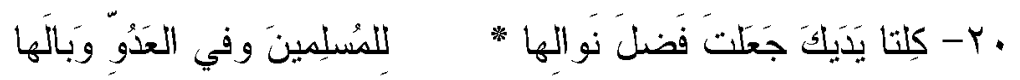
فالتساؤل البلاغي الموحي بمرارة الفقد في قصيدة الرثاء:

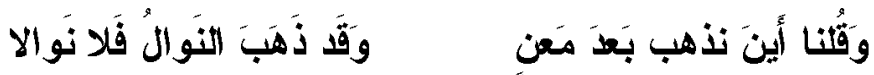

الذي وضع الشاعر في موضع الجرم - شعريًا - كان من الضروري التكفير عنه شعريًا في قصيدة

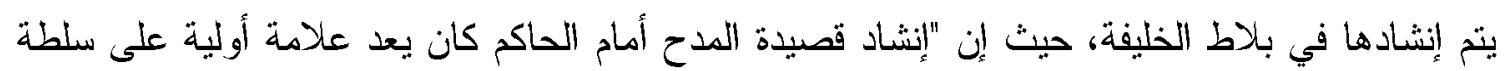

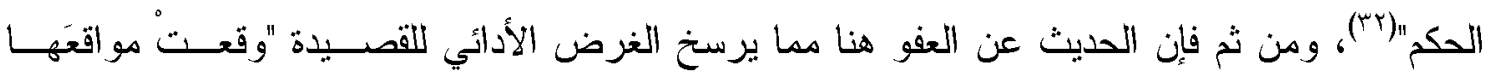
بعفوكَ أنفسه" البيت آ و، ويؤكد على البعد التأثيري للخطاب، وعندما يلتمس مروان بن أبي حفصة كرم الخليفة و عفوه فإنه يستخدم صيغة للجمع تشمل الناس جميعًا ليثبت جدارته بعطاء الخليفة و عفوه لانتسابه

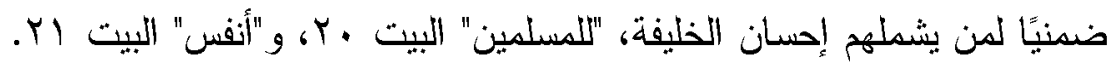
كذلك يبرز دور التشكيل اللغوي في تأكيد فضائل الخليفة حيث يعد مروان إلـى اســتخدام الفعـل

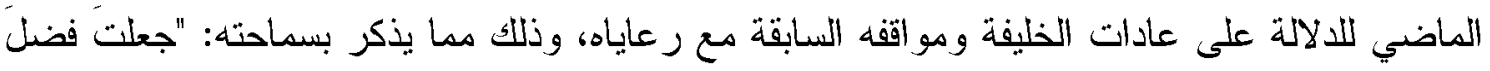

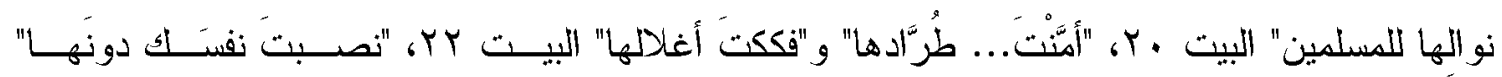

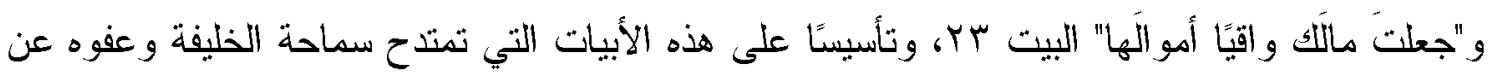

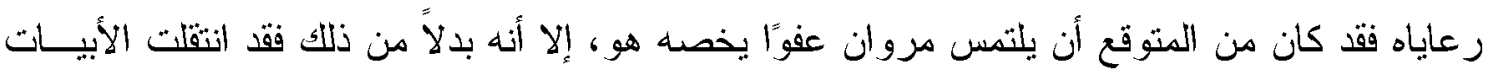
انتقالًا مفاجئًا و غبر متوقع من خطاب الخليفة إلى مخاطبة أعداء الخليفة.

$$
\text { المقطع الثالث: الأبياث ع ب - مب }
$$

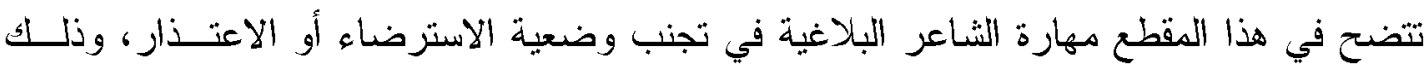

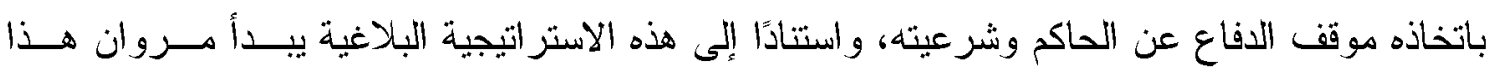
المقطع بتثبيت شعرية صوته المادح، مستعيزًا من التراث الشعري الذبي ينتمي إليه مفهوم تفرد الممدوح

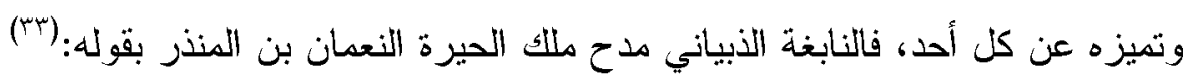

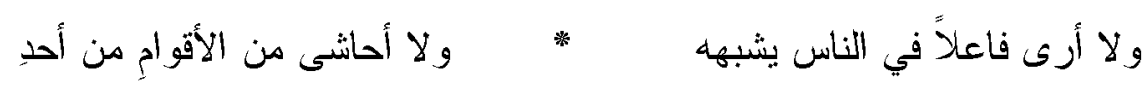
وكذلك مدح علقمة الفحل الملك الحارث بقوله:(؛ّ)

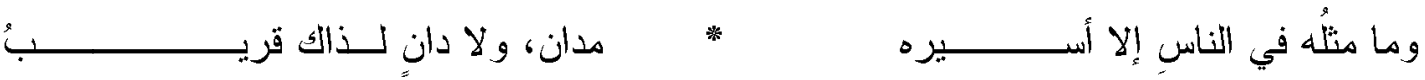

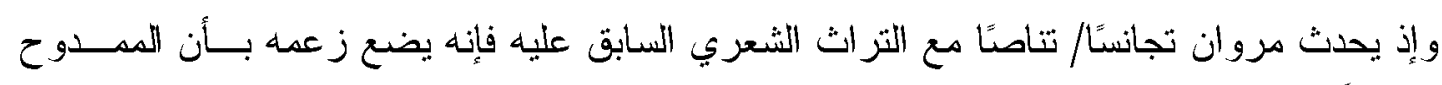
ليس مماثلاً للآخرين في صيغة استفهام بلاغي يحمل نبرة التحدي للخصوم:

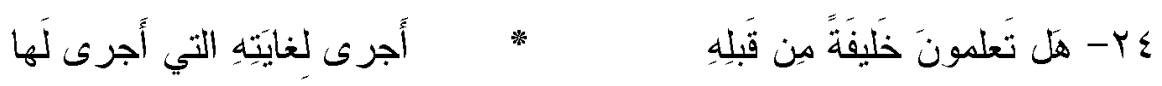


لا يؤكد الاستفهام البلاغي في البيت ؟Y قوة الخليفة فحسب، حيث إن موقعه في القصيدة بعد مقطع

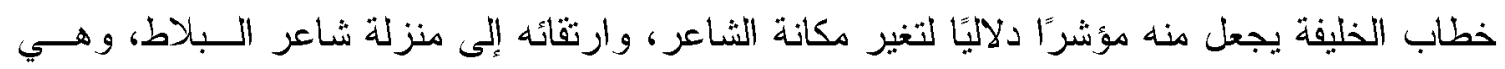

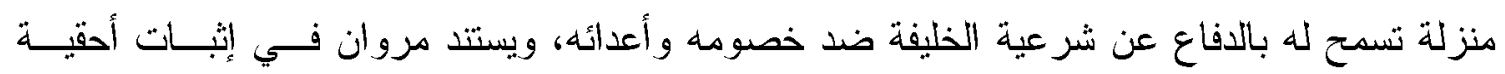

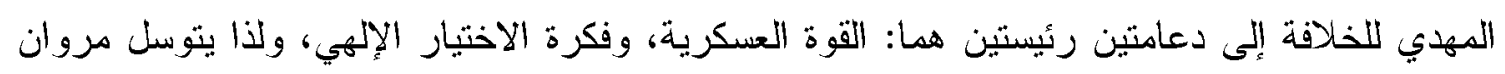

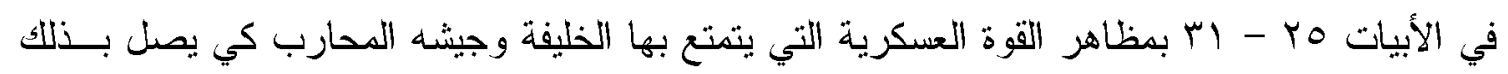

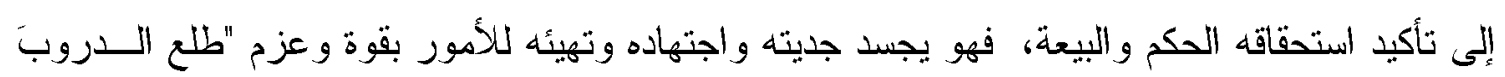

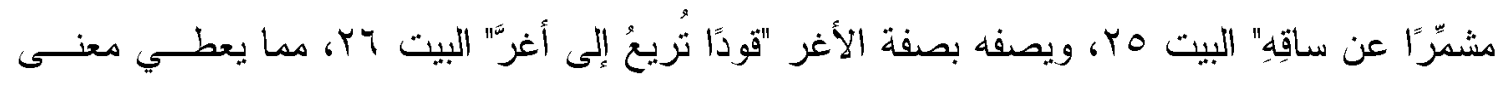

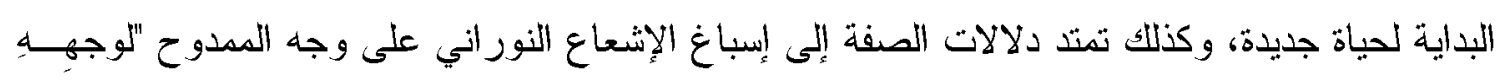

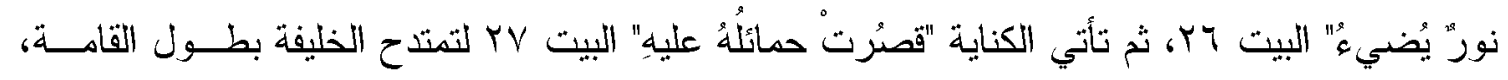

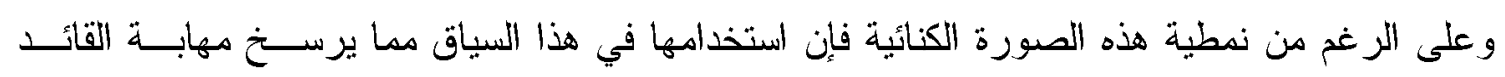

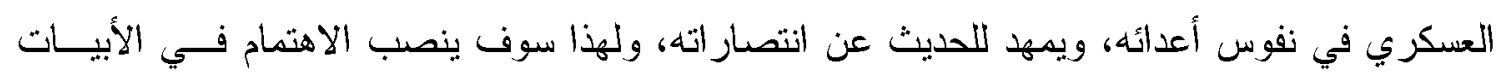
التالية على فكرة الغزو، ويختار مروان من بين غزوات الخليفة المتعددة حملته الحربية الناجحة لحماية

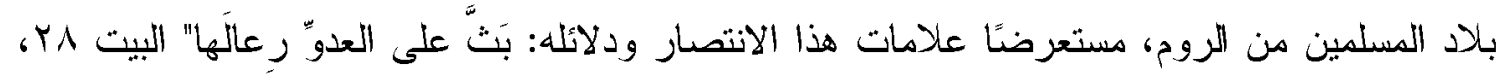

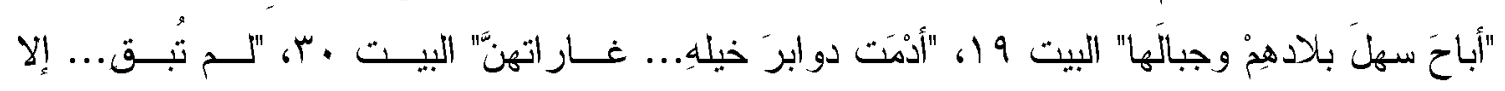

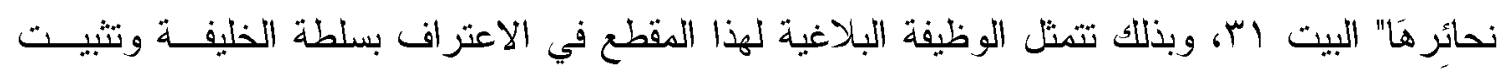
شرعيته، والأهم من ذلك الإقرار بمبايعته، لأن جهاد الخليفة ضد أعداء أمته لا يدل على قوته العسكرية فحسب، و إنما بضمن شرعيته الحاكمة أيضًا.

تتميز الأبيات بس - ؟ب بخلبة أسلوب الحجاج من أجل إثبات أحقية العباسيين للخلافة، ويتبين فيهـا

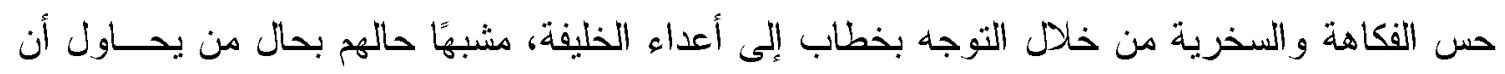
بطمس نجوم السماء أو يستر هلالها بالأكف، ويضع مروان هذا المشهد بما بتضمن من ســخرية فــي صيغة استفهام بلاغي: - مبرم

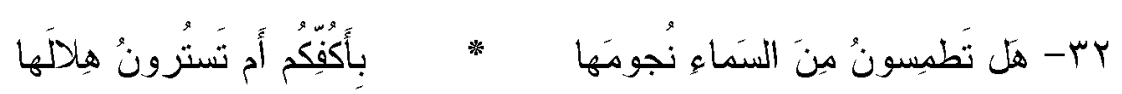

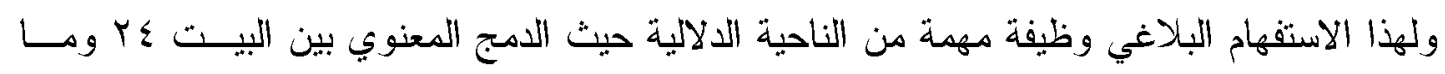

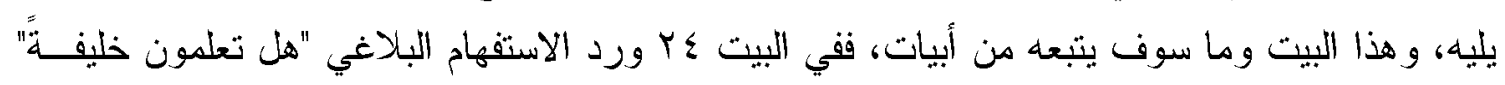

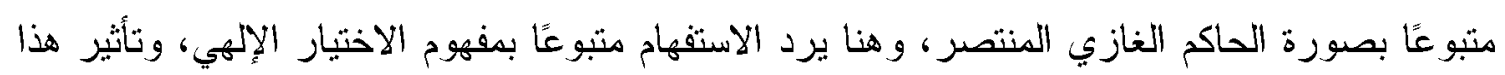

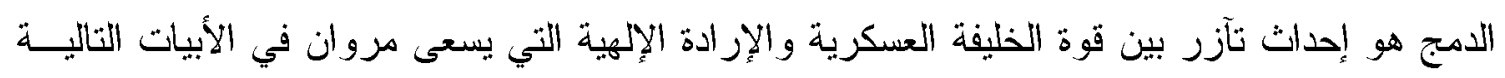

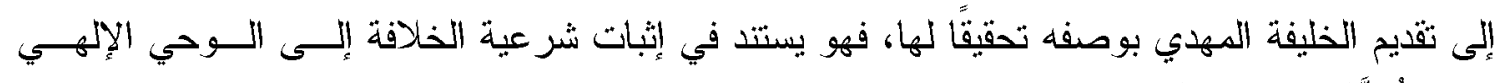

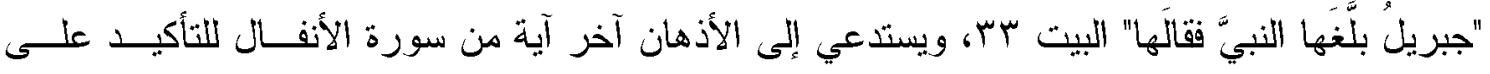

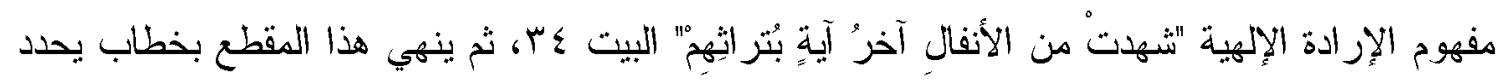

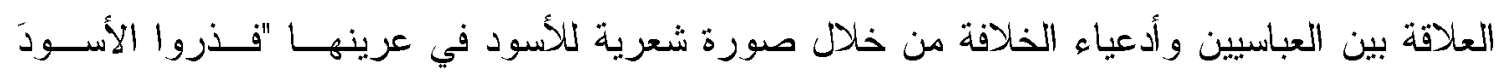

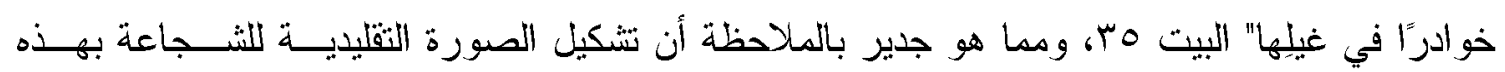


الصياغة الخطابية قد أضفى بعدًا أسطوريًا للمكانة التي يتمتع بها خلفاء بني العباس، ورلـــا كــان مــن

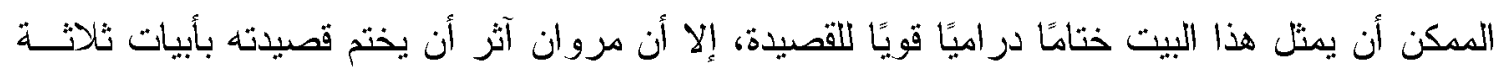
توجز رسالة هذا النص الشعرب، وتحدد غرضه الأدائي.

يتحول الأسلوب في الأبيات الأخيرة من الخطاب السياسي الحاد ضد أعداء الخليفة إلى نبرة غنائيــة

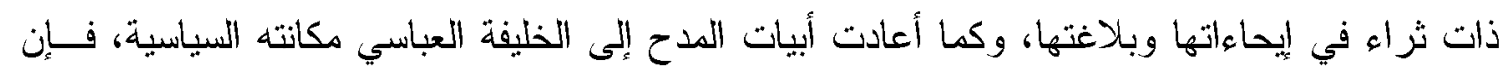
هذه الأبيات تهدف إلى استعادة مروان بن أبي حفصة مكانته الثعرية، وتتمثل الفعالية البلاغية لاستخدام

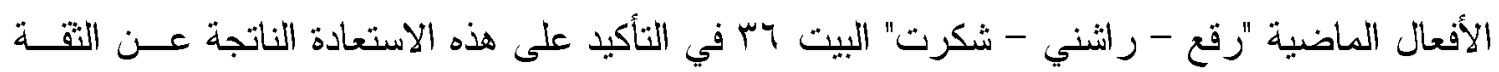
المطلقة في أن تحوز القصيدة على إعجاب الخليفة، وبالتالي فإنه سوف يجزل اللشاعر العطاء، وكـــللك تمثل عبارة "شكرت نو الَها" في البيت نفسه رسالة اعتذار أخرى تتوازى ورسالة الاعتذار المتضمنة في وني

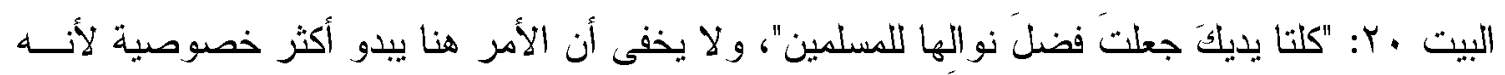

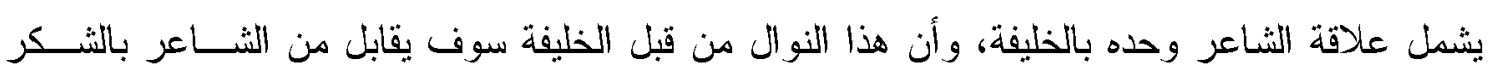
المتمثل في هذه القصيدة المتميزة بجمالها وبلاغتها. تأسيسًا على الاستعادة التي حاز ها الثاعر بقصيدته المدحية تتصاعد قوته وتتضضاءل قــوة منافســيه

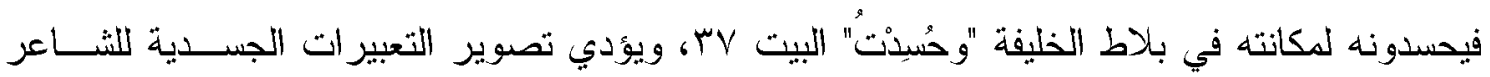
المتن لعطاء الخليفة دورًا مهـًا في تقديم الذات من خلال صورة حركية لا تخلو من الزهو و الخـبلاه

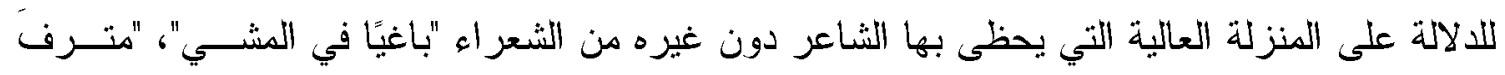

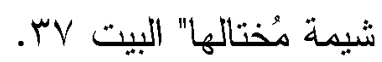
و هكذا لم يكن مستغربًا أن ينهي مروان قصيدته بخطاب الخليفة مرة أخرى، فهو من سـوف يخفــر للشاعر ذنبه الثتعري، ويمنح المكافأة التي تتناسب و القوة البلاغية للقصيدة:

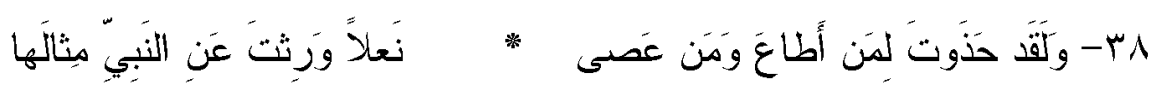
تبرز هنا ثنائية الطاعة والعصيان التي تحرك الخطاب من العام إلى الخاص، وتؤدي دورًا مهمًا في

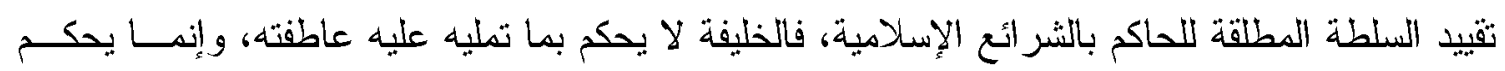
وفق التز امه الديني و الأخلاقي اللذين هما من ميراث النبوة، وبذلك يصبر و اضحًا في نهاية القصيدة أنها

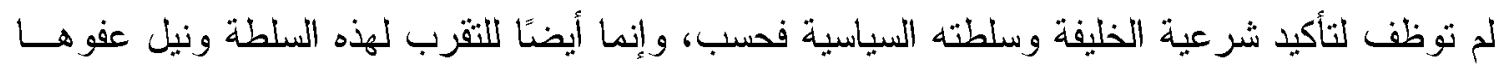

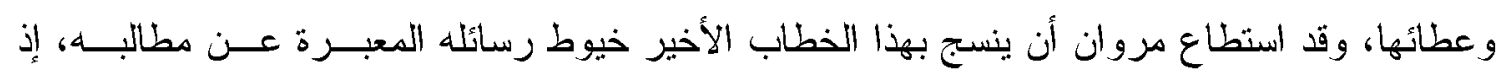
بتو ازى هذا الخطاب مع أبيات أخرى في القصبدة شكلها الأسلوب الخطابي، بوصفها رسائل من الشاعر

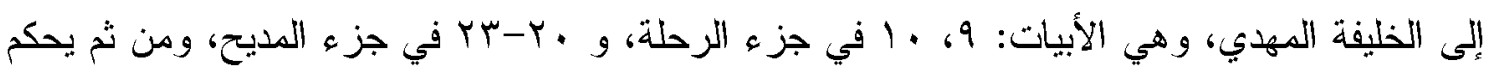

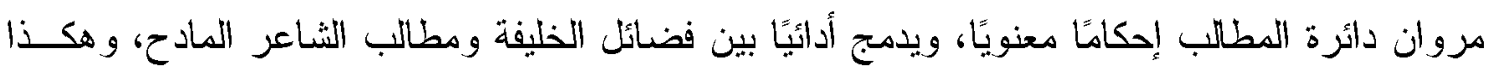
فإن المديح في هذه القصبدة ليس تملقًا للخليفة فحسب، ودئ وإنما محاولة للتذكير بما يتمتع به الخليفة من قيم

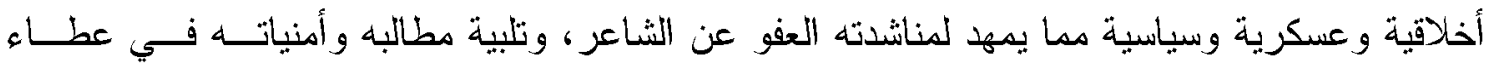


عرض التقليد الأدبي سياق القصيدة التداولي، وقدم تلقى الخليفة المهدي للقصيدة في صــورة تعبـر عن تماهيه مع رؤيتها الثتعرية، فقد عرضت الأخبار المصاحبة للقصيدة اهتمام الخليفة البالغ بالقصــيدة

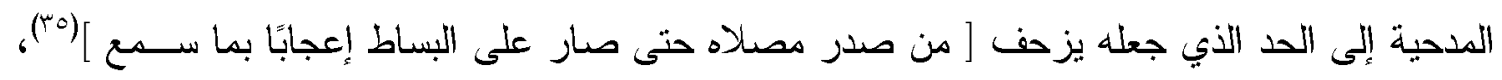

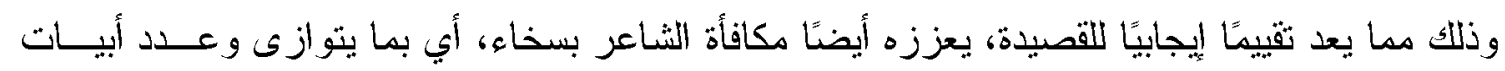

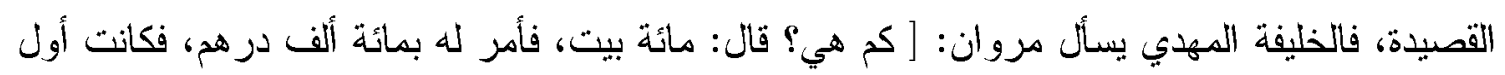

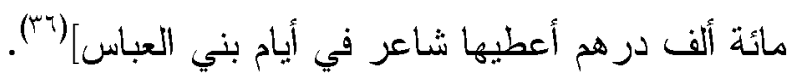
إن القيمة التفسيرية لهذا الأمر الذي أصدره الخليفة المهدي إنما تتمثل في تحقق الغــرض الأداتـي

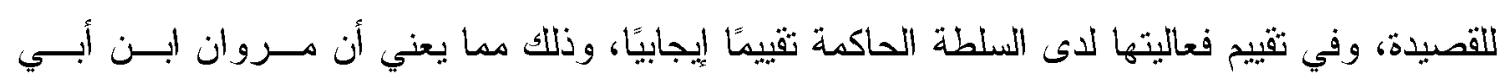
حفصة قد استطاع أن يبدع قصيدة استعاد بها مكانته الثعرية، و استعاد بها هيبة الخليفة في إطار بنيـة ولئة مجتمعية تحفظ للنظام السياسي معاييره وتقاليده، ولذا فإن إلحاح السياق الأدبي على أن يجمع بين قصيدة

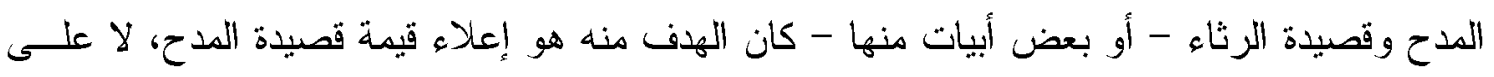
المستوى البلاغي فحسب، و إنما أيضًا على المستويين السياسي و الاجتماعي.

\section{لالخاتمـــة}

سعت هذه الاراسة بالاستعانة بالمناهج النقدية الحديثة التي تحقهت في مجالات التداولية وعلم النص

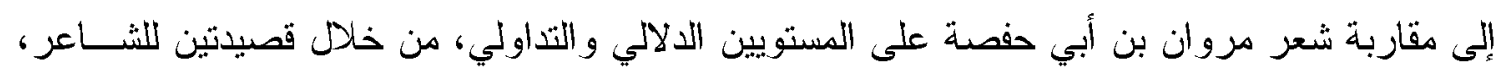
إحداهما في الرثاء والأخرى في المدح، وذلك في ضوء ما صاحبهما من أخبار حول الظروف السباسية

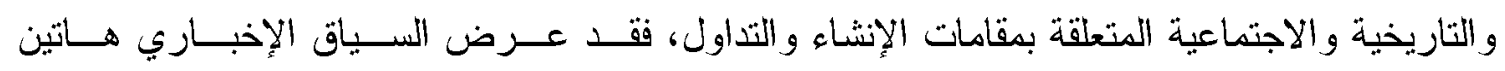

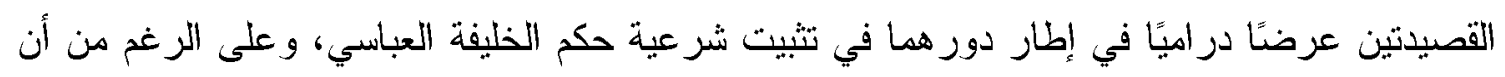

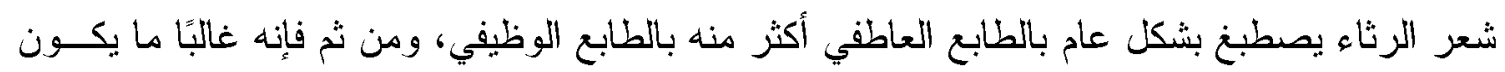

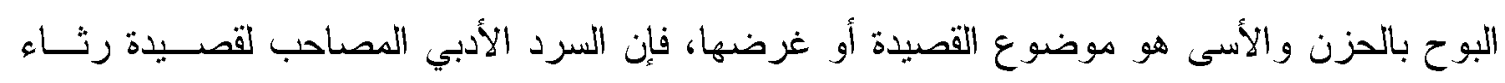

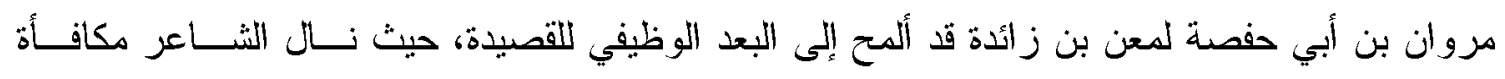

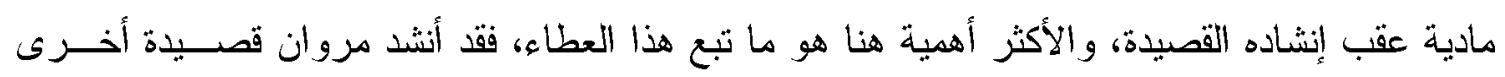

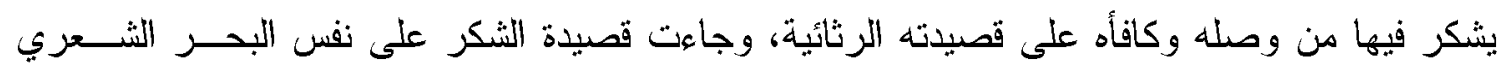

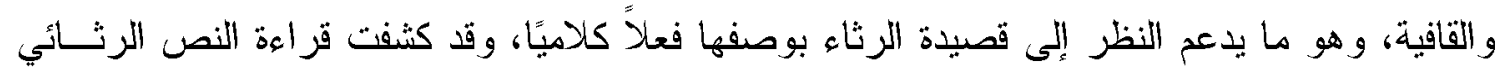

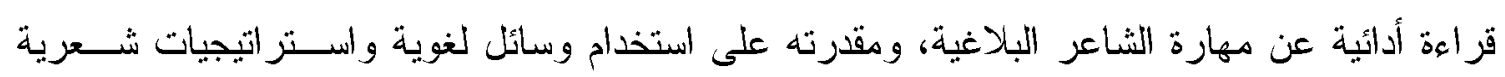

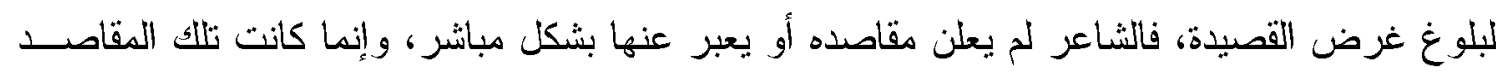
كامنة في بنية القصبدة وفي اختبار موضوعها.

من ناحية أخرى عرض السرد الأدبي قصيدة الرثاء بوصفها شكلًا من أشكال الإهانة لمقام الخليفــة العباسي، وذلك بسبب الدلالة المتضدنة في بعض أبياتها التي تدور حول فكرة الكرم، و إعلان الثــاعر

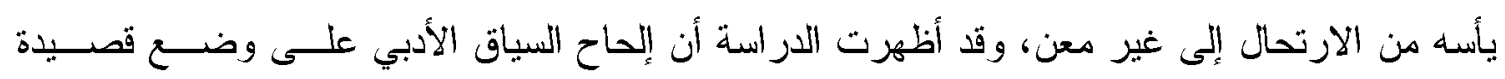
الرثاء في إطار الذنب الثتعري كان يهدف إلى إعلاء هيمنة الخلافة العباسية، في ظل فكرة التنافس على الى 
السلطة السياسية، ومن ثم إنشاد قصائد مدح/اعتذار تعمل على استعادة هيبة الخليفة، والتأكيد على علــو

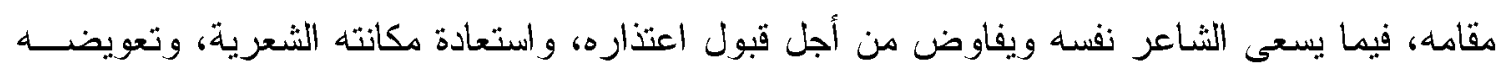
بعطاء مادي يكافئ بلاغة قصيدته المدحية، وبحسب السياق التداولي الأبي عرضه السرد الأدبي لقصيدة

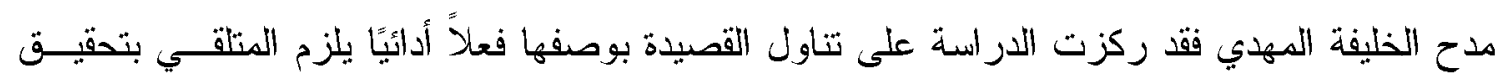
استجابات متوقعة من الشاعر، وأظهر التحليل النصي تتوع مستويات الأداء، ومن أهمها: ا- توظيف تقاليد النسيب من أجل إثر الك عواطف المتلقي مع الثـاعر الذب يعاني على يـــد خيـال

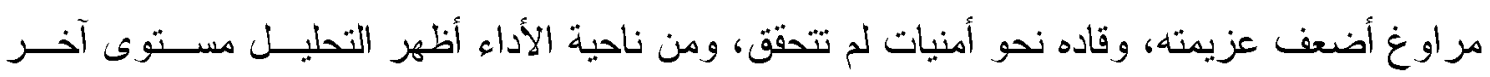

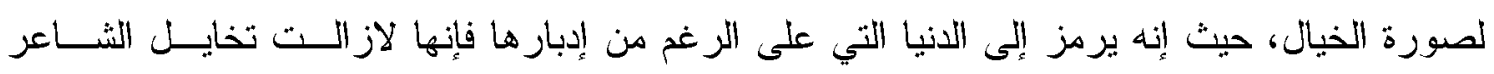

ץ- عرض جزء الرحلة بدابات التعبير عن الولاء السياسي للخليفة العباسي، و التخلي عـن الــولاء

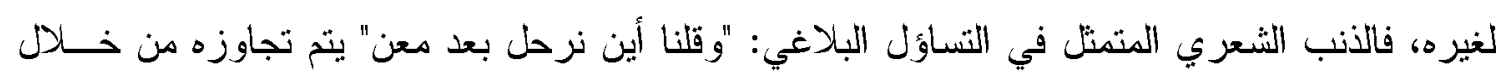

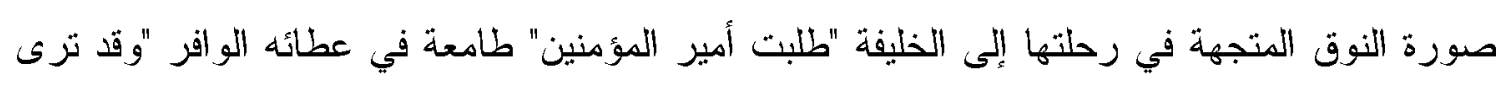

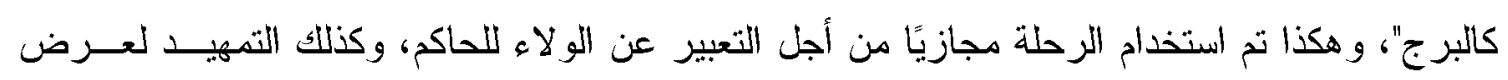
المطالب.

ب- تعددت الرسائل الموجهة إلى الخليفة وتتوعت بين ما هو صريح كما في الأبيـات: ^، 9، باء بس، VY،

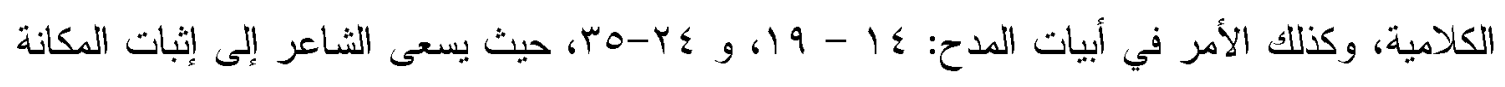

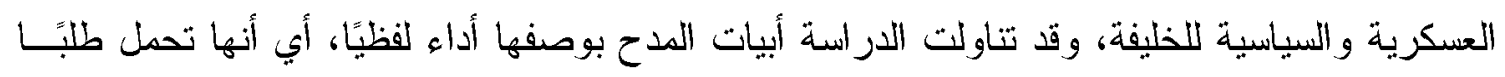
ضمنيًا بمنح مكافأة للشاعر على قصيدته. تشير الدراسة إلى أهمية قز اعة القصائد العربية في ضوء سياقاتها، لأن ذلك مما بسهح في تفسـبرها

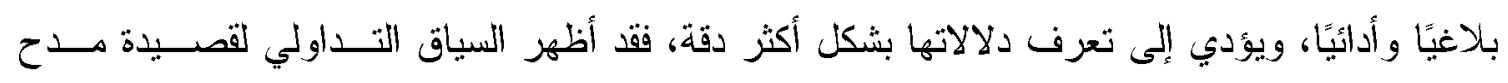

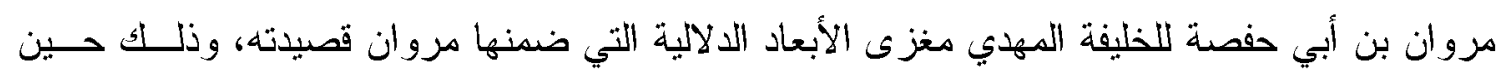
عرض السرد الأدبي كيفية تعبير الخليفة المهدي عن إعجابه بالقصيدة، مما يعني أن مروان بــن أبسي حفصة قد استطاع بمهارة بلاغية واضحة إقناع الخليفة المهدي بالعفو عنه، وبإعادة إعطائه المكانة التي لئي

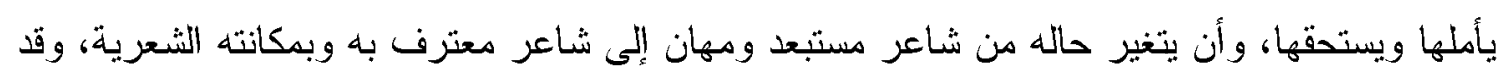

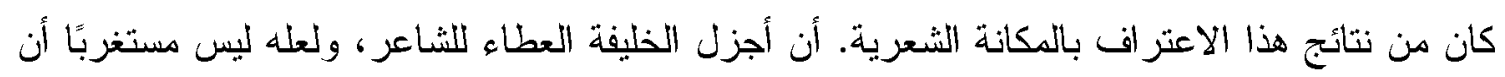
يوجز مروان تلك المعاني في خاتمة القصيدة، فيعلن أنه حسد من منافسيه، وأن مشيته بعد عطاء الخليفة

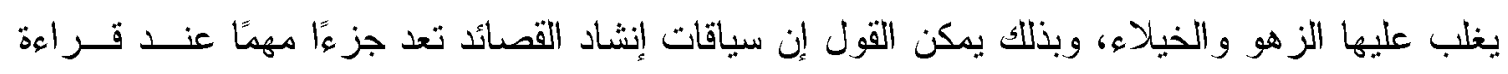
النص الشعري، فهي تكتسب أهميتها من استيعابها لدلالاته، وتتبيهـها المتلقي إلى ملامح النص البلاغية. 


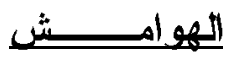

1- المقاربة التداولية، فرانسواز أرمينكو، ترجمة: سعيد علوش، (ط مركــز الإنمــاء القـومي،

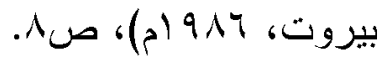

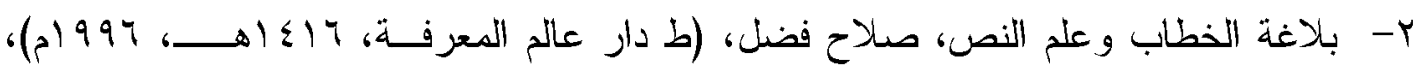

$$
\text { ص19. }
$$

ץ- المقاربة التداولية، فر انسواز أرمينكو، ترجمة: سعيد علوش: صبr.

ع- التداولية وتحليل الخطاب، مارغاريدا باسولز بويخ، ترجمة: سناء عبد العزيز، ضمن مجلــة

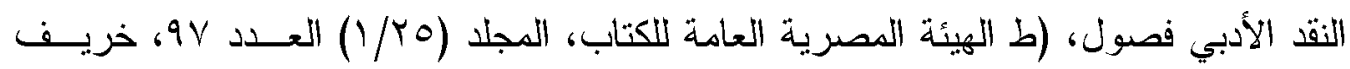

$$
\text { ( T) }
$$

ه- النص: بنى ووظائف، مدخل أولي إلى علم النص، نون آ. ثان ديك، ضمن: العلاماتية و علــم

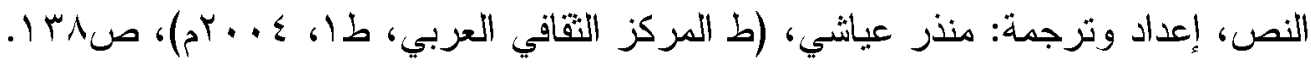

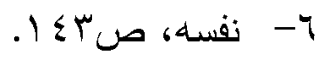

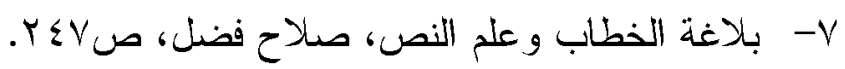

1- النص: بنى ووظائف، مدخل أولي إلى على النص، نون آ. ثان ديك، ضمن: العلاماتية وعلـم

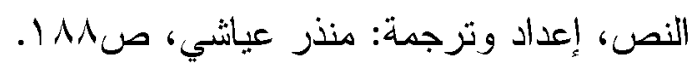

9- النص: جان ماري سشايفر، ضمن: العلاماتية وعلم النص، إعداد وترجمة: منـذر عياشـي، ص

• ا- مدخل إلى علم لغة النص، تطبيقات لنظرية روبرت ديبوجر اند ولفجانج دريسلر ، إلهــام أبــو غز الة و علي خليل حمد، (ط الهيئة المصرية العامة للكتاب، طب، 999 (م)، صوجن. الا- النص، جان ماري سشايفر، ضمن: العلاماتية وعلم النص، إعداد وترجمة: منـذر عياشــي، صع

ب ا النص، بنى ووظائف، مدخل أولي إلى علم النص، تون آ. ثان ديك، ضمن: العلاماتية و علـــ

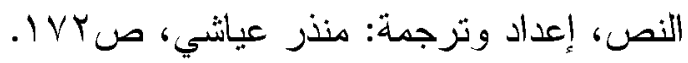

با - أدب السياسة وسياسة الأدب، سوزان بينكنى ستيتكيفيتش، ترجمة وتقديم: حسن البنا عز الدين بالاشتر اك مع المؤلفة، (ط الهيئة المصرية العامة للكتاب، 991 (م)، صلVه.

؛ ا-لسانيات النص، مدخل إلى انسجام الخطاب، محمد خطابي، (ط المركز الثقافي العربي، طا،

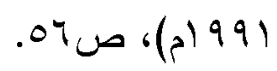


1 ا - المكون الحجاجي في الخبر، حنان المدر اعي، ضمن: بلاغة النص التراثي - مقاربة بلاغيـة

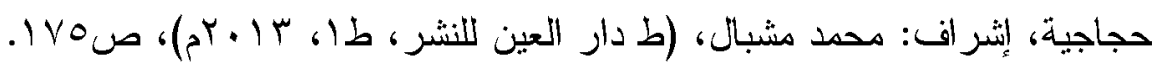
جا-في نظرية الأدب عند العرب، حمادي صمود، (ط النادي الأدبي التقــافي بجـدة، .99 (م)،

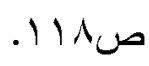

IV

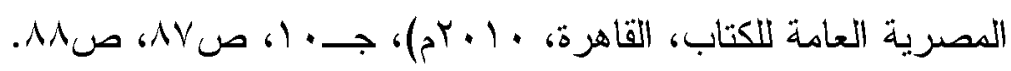

1ا-شعر مروان بن أبي حفصة، جمعه وحققه وقدم له: حسين عطوان، (ط دار المعارف، طب)، صن 9 ا - المقام البلاغي بين التراث العربي و الدراسات البلاغية المعاصــرة، إبــر اهيم بـن منصــور

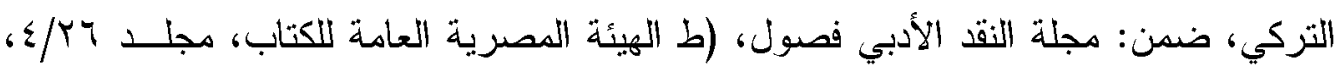

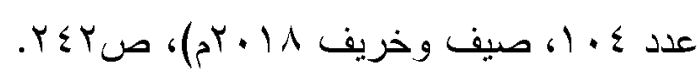
. - شعر مروان بن أبي حفصة، صعـ. اب-تحليل الخطاب الثُعري (استر اتيجية التتاص)، محمد مفتاح، (ط المركز الثقافي العربي، الدار

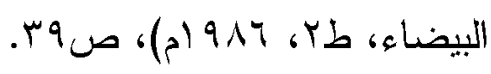

YY - النص: بنى ووظائف، مدخل أولي إلى علم النص، تون آ. ثان ديك، ضمن: العلاماتية وعلــ النص، إعداد وتزجمة: منذر عياشي، صاءي 191. r M-شعر مروان بن أبي حفصة، ص99.

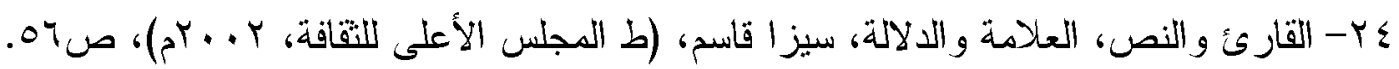

$$
\text { هץ- الأغاني، لأبي الفرج الأصفهاني، جـ·•(، صبA. }
$$

جب- انظر : منهاج البلغاء وسر اج الأدباء، صنعة أبي الحسن حازم القرطاجني، تقـديم وتحقيـق:

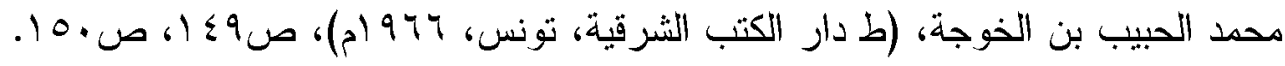

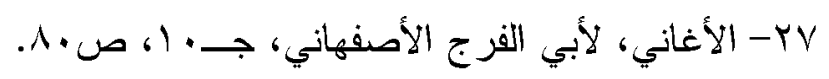

^ץ- دلائل الإعجاز، عبد القاهر الجرجاني، حققه وقدم له: محمد رضوان الدابــة ومحمــد فــايز

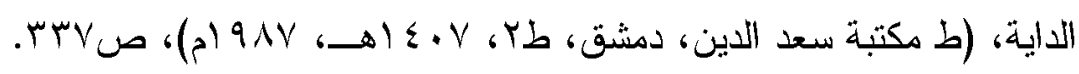

$$
\text { وץ- الأغاني، لأبي الفرج الأصفهاني، جـ·• صـ صـ. }
$$

• ب- القصبيدة و السلطة، الأسطورة، الجنوسة، و المر اسم في القصبدة العربيــة الكلاســيكية تـألبف :

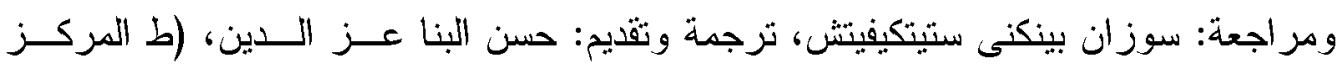

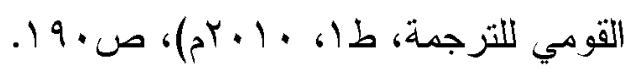


اب-شعر مروان بن أبي حفصة، ص797. Yب- أدب السياسة وسياسة الأدب، سوزان بينكنى ستيتكيفيتش، ترجمة وتقديم: حسن البنا عز الدين

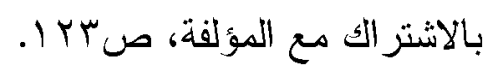
بr- ديوان النابغة الذبياني، تحقيق: محمد أبو الفضل إبراهيم، (ط دار المعارف، طب)، ص. ؟ب.

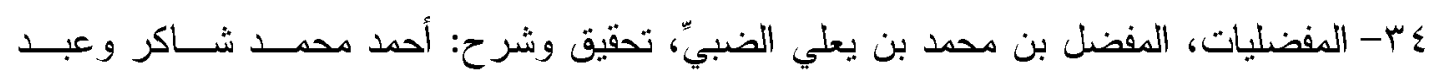

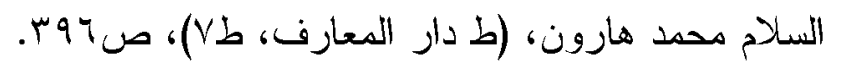

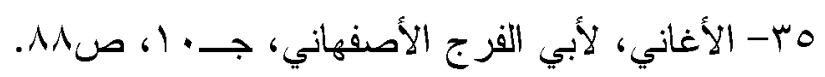

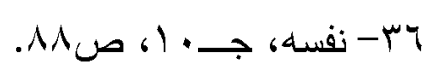

الملخص :

تسعى هذه الدراسة إلى تحليل النص الثعري من حيث ارتباط بنيته بالسباق الثقافي، أبي بظروف إنتـاج النص وتلقيه وتأويله، وذلك بالاستاد إلى ركنين أساسيين، أولهما: النص نفسه، وثانيهما: مـــ يصـاحبه من أخبار سردية سوف يتم تتاولها بوصفها بنية أدبية تسهم في التعرف على المظــاهر غيــر اللســانية للنص، وتسعى الدراسة مستعينة بالنظريات النقدية الديثة إلى مقاربة شعر مزوان بن أبي حفصة على تلى المستويين الدلالي و التداولي، من خلال قصيدتين للثاعر، إحداهما في الرثاء والأخرى في الددح، وذلك في ضوء ما صاحبهما من أخبار حول الظزوف السياسية والتاريخية والاجتماعيـة المتعلقـة بمقامـات

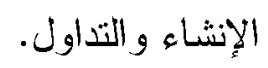

الكلمات المفتاحية: النص الثعري - السياق الثقافي - مروان بن أبي حفصة - الدلالي والتداولي. 


\section{Semantic and Rhetorical Situation in Marwan Ibn AbiHafsa's Poetry}

\section{Abeer Elewa Ibrahim}

This study aims at analyzing poetry regarding the correlation of its structure with the cultural context, i.e. the circumstances in which it was written, published, and interpreted. This depends on two major points, The first is the poem itself, and the second is the narrative that accompanies it, which will be discussed as a literary structure that contributes to acknowledging the nonlinguistic aspects of the poem.

The study also aims at approaching the poetry of Marwan Ibn AbiHafsa on a deliberative and semantic level with the help of modern critical theories using two of his poems, one poem is lament, and the other is panegyric. This approach is in view of the accompanying political, historical, and social conditions that are related to the rhetorical situation.

Keywords: Poetry, Cultural context, Marwan Ibn AbiHafsa, Semantic and rhetorical situation. 